\title{
Tracking Global Demand for Advanced Economy Sovereign Debt
}

Serkan Arslanalp and Takahiro Tsuda 


\title{
IMF Working Paper
}

\author{
Monetary and Capital Markets Department
}

\section{Tracking Global Demand for Advanced Economy Sovereign Debt ${ }^{1}$}

\author{
Prepared by Serkan Arslanalp and Takahiro Tsuda
}

\author{
Authorized for distribution by Udaibir S. Das
}

December 2012

\begin{abstract}
This Working Paper should not be reported as representing the views of the IMF.
The views expressed in this Working Paper are those of the author(s) and do not necessarily represent those of the IMF or IMF policy. Working Papers describe research in progress by the author(s) and are published to elicit comments and to further debate.
\end{abstract}

\begin{abstract}
Recent events have shown that sovereigns, just like banks, can be subject to runs, highlighting the importance of the investor base for their liabilities. This paper proposes a methodology for compiling internationally comparable estimates of investor holdings of sovereign debt. Based on this methodology, it introduces a dataset for 24 major advanced economies that can be used to track US\$42 trillion of sovereign debt holdings on a quarterly basis over 2004-11. While recent outflows from euro periphery countries have received wide attention, most sovereign borrowers have continued to increase reliance on foreign investors. This may have helped reduce borrowing costs, but it can imply higher refinancing risks going forward. Meanwhile, advanced economy banks' exposure to their own government debt has begun to increase across the board after the global financial crisis, strengthening sovereign-bank linkages. In light of these risks, the paper proposes a frameworksovereign funding shock scenarios (FSS) - to conduct forward-looking analysis to assess sovereigns' vulnerability to sudden investor outflows, which can be used along with standard debt sustainability analyses (DSA). It also introduces two risk indices-investor base risk index (IRI) and foreign investor position index (FIPI) — to assess sovereigns' vulnerability to shifts in investor behavior.
\end{abstract}

JEL Classification Numbers: F3, G01, G11

Keywords: International Finance, Financial Crises, Portfolio Choice and Investment Decisions.

Authors' E-Mail Addresses: sarslanalp@imf.org; ttsuda@imf.org

\footnotetext{
${ }^{1}$ We are grateful to Ali Abbas, Jochen Andritzky, Tamim Bayoumi, Fabian Bornhorst, Engin Dalgic, Udaibir S. Das, Reinout De Bock, Mark De Broeck, Selim Elekdag, Luc Everaert, Maximilian Fandl, Anastasia Guscina, Allison Holland, Anna Ivanova, Mariusz Jarmuzek, Peter Lindner, Silvia Merler, Yanliang Miao, Franziska Ohnsorge, Rafael Romeu, Miguel Segoviano, Eriko Togo, Justin Tyson, and participants at the IMF MCM Seminar for their insights and comments and Gabriel Presciuttini for excellent research assistance. Any remaining errors are our own.
} 


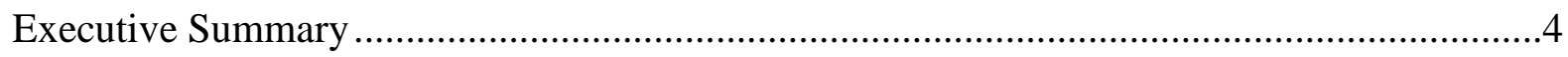

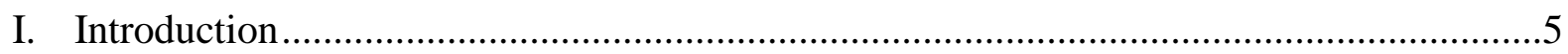

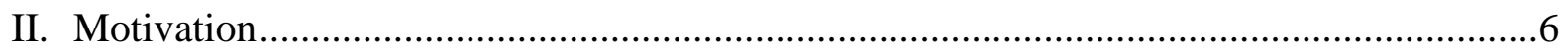

III. Methodology for Sovereign Investor Base Estimates.......................................................

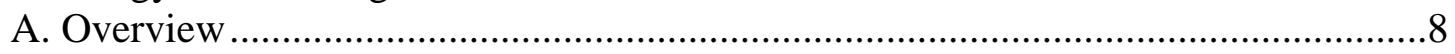

B. Estimation Methodology for Each Investor Type ……………………...................14

C. Robustness Checks and Adjustments ..................................................................19

D. Limitations and Extensions ..............................................................................20

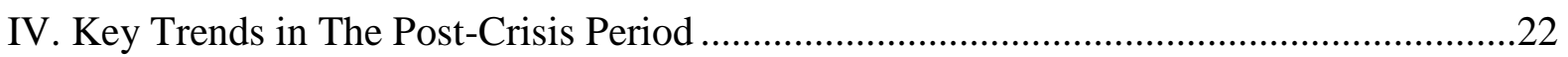

A. How Did Foreign Demand Change? ................................................................22

B. How Did Foreign Demand Change by Investor Type?...........................................28

C. How Did Domestic Investors React to Falls in Foreign Demand? ...........................31

D. How Did Domestic Bank Demand Change More Generally? .................................32

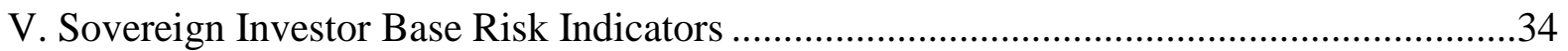

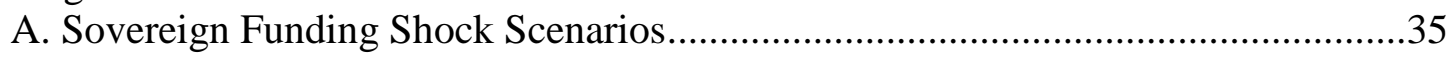

B. Investor Base Risk Index..................................................................................

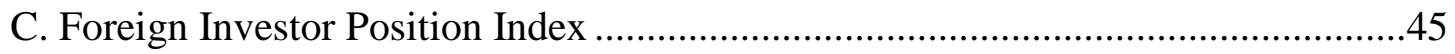

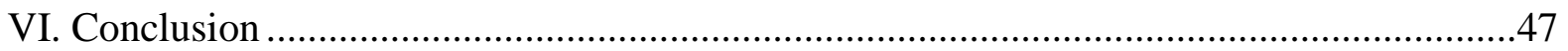

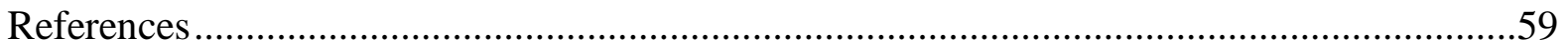

Tables

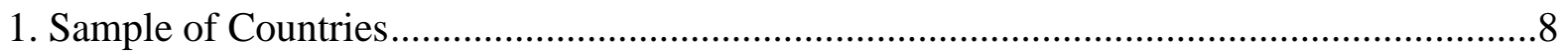

2. Summary of Data Sources ..........................................................................................

3. Construction of General Government Gross Debt on a Consolidated Basis for Non-

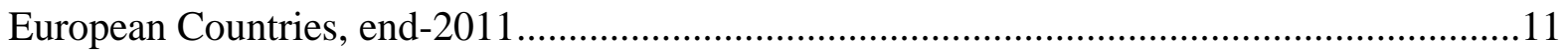

4. Valuation of Debt Securities in Various Databases ...........................................................13

5. Estimation of Foreign Central Bank Holdings of Government Debt, end-2011 ..................16

6. Risk Scores by Investor Type ……………………….......................................................4

Figures

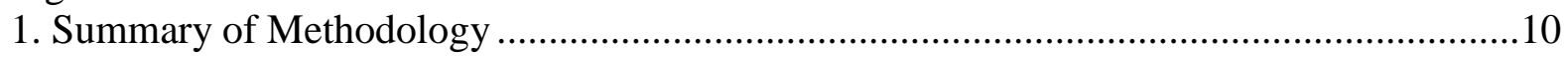

2. Advanced Economies: Holders of Government Debt, end-2011 .......................................12

3. Foreign Holdings of Government Debt by Country of Origin, 2004-11 ……...................22

4. Advanced Economies: Foreign Investors as an Investor Class, 2004-11 ..........................23

5. Advanced Economies: Foreign Share in Government Debt Stock, 2004-11 .....................25

6. Advanced Economies: Foreign Net Purchases and Sales of Government Debt, 2008-11..26

7. Euro and Non-Euro Area: Foreign Holders of Government Debt .....................................26

8. Advanced Economies: Changes in Sovereign Credit Ratings, 2004-11 …........................27

9. Euro and Non-Euro Area Countries: Foreign Net Purchases of Government Debt ............28 
10. Advanced Economies: Country Allocation of Foreign Investors, 2004-11 ...................29

11. Advanced Economies: Cumulative Net Foreign Purchases of Government Debt ............30

12. Advanced Economies: Foreign Investors' Portfolio Reallocation in 2011 ......................30

13. Foreign Investors Position and Sovereign Downgrades, 2004-11 .................................31

14. Advanced Economies: Bank Holdings of Own Government Debt, 2004-11 ..................32

15. Euro and Non-Euro Area: Bank Holdings of Own Government Debt, 2008-11 .............32

16. Euro Area: Bank Holdings of Own Government Debt Securities, 2007-11 …...............33

17. Advanced Economies: Sovereign Funding Shock Scenarios ........................................39

18. Advanced Economies: Investor Base Risk Index, 2008-11 .......................................42

19. A Stylized Framework for Sovereign Risk Analysis ...............................................43

20. Advanced Economies: Application of Investor Base Risk Index, end-2009..................44

21. Advanced Economies: Foreign Investor Position Index (FIPI), end-2011 .....................46

Boxes

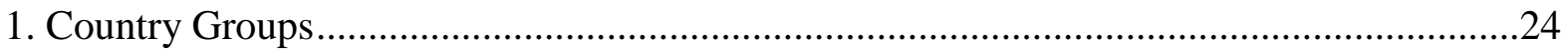

2: Methodology of Sovereign Funding Shock Scenarios .................................................36

Annex Figures

1. Advanced Economies: Holders of Government Debt, 2004-11....................................50

2. Advanced Economies: Cumulative Purchases of Government Debt, since end-2007........55 


\section{EXECUTIVE SUMMARY}

This paper aims to make three contributions. First, it introduces a methodology to compile internationally comparable estimates of sovereign debt holdings. Second, it identifies some common trends in investor holdings of advanced economy sovereign debt. Third, it proposes a set of risk indicators to analyze sovereigns' vulnerability to sudden investor outflows.

Lack of standardized data on holdings of sovereign debt hinders the analysis of demand-side dynamics for sovereign debt. The methodology that is proposed in this paper can be used to track US\$ 42 trillion of sovereign debt issued by 24 major advanced economies and held by six different investor classes - domestic central banks, domestic banks, domestic nonbanks, foreign official sector, foreign banks, and foreign nonbanks. The dataset, which covers the period from 2004 to 2011 on a quarterly basis, is publicly available along with this paper.

Our analysis suggests that foreign investors continue to increase their share in sovereign debt markets, apart from the euro area periphery (Figure 5). While high foreign interest in a sovereign may be a signal of confidence, higher reliance on foreign investors can also imply rising government refinancing risk. This risk has materialized in the euro area periphery, where foreign investors reduced exposure to sovereign debt by about US\$400 billion between mid-2010 and end-2011, according to our estimates (Figure 11). The outflows were across the board among foreign central banks, foreign banks, and foreign nonbanks. They varied, however, in terms of scale, speed, and timing, reflecting different risk characteristics.

In all cases where there were large foreign private outflows, domestic banks stepped in to fill most of the financing gap that were not filled by the foreign official sector. While it follows that domestic banks can help mitigate refinancing risk, this came at the cost of deeper sovereign-bank linkages that may jeopardize domestic financial stability over the long term. This issue is of particular concern because advanced economy banks' exposure to own government debt is on the rise since 2008 (Figure 14). This may reflect cyclical factors, such as weak growth conditions in most advanced economies, as well as structural factors, such as banks' need to deleverage after the global financial crisis, preparations for implementing the new financial regulations including Basel III, and possibly home bias.

Taken together, advanced countries could face more uncertain funding conditions in the future given their higher reliance on foreign investors and growing exposure of their banks to own government debt. In light of these potential risks, the paper proposes a frameworksovereign funding shock scenarios (FSS) - that can be used along with standard debt sustainability analyses (DSA) to assess sovereigns' vulnerability to sudden investor outflows (Figure 17). It also introduces two risk indices-investor base risk index (IRI) and foreign investor position index (FIPI) — that can be used to assess and monitor sovereigns' vulnerability to shifts in investor behavior (Figures 20-21).

The paper concludes with some policy implications. It calls for integrating robust sovereign investor base analysis into public debt management, financial sector supervision, and sovereign risk measurement. It also highlights the need to further reduce data gaps in securities holding statistics, in line with the G20 Data Gaps Initiative. 


\section{INTRODUCTION}

There has been a lot of discussion about how the supply of sovereign debt changed after the global financial crisis, but less attention has been paid to how the demand side has been changing. The general government gross debt of advanced economies increased rapidly from 74 to 105 percent of GDP over 2007-11. Based on latest IMF World Economic Outlook (WEO) projections, it will stabilize at around 110 percent of GDP in 2014. Similar statistics on the demand for sovereign debt are harder to come by, in particular regarding the holders of the debt and how they are changing their allocations. Yet, as recently witnessed in a number of euro area countries, shifts in the investor base for sovereign debt can have significant effects on government borrowing costs, as well as market access, even in the absence

General Government Gross Debt (percent of GDP)

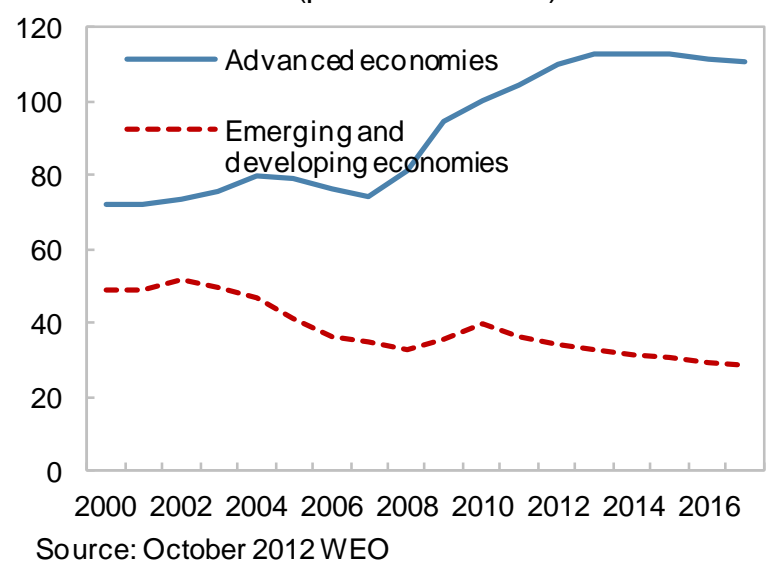

of material changes in the outstanding supply of government debt.

The lack of internationally comparable investor base estimates hinders the analysis of demand-side dynamics for sovereign debt, in particular for cross-country analysis. Having a cross-country view of the sovereign investor base is essential for understanding demand dynamics, as changes in the country allocations of international investors affect many countries at the same time, with some losing and some gaining an important source of demand. Similarly, only internationally comparable data allow us to aggregate investor flows across countries to examine changes in the asset allocation of international investors. However, there is currently no such dataset: (i) investor base data available from national debt management offices (DMOs) are not always comprehensive as they usually cover only a subset of government debt (e.g., central government); (ii) national flow of funds data are not always internationally comparable; and (iii) data from private sector vendors (e.g. survey or custodial data) usually cover only a small share of the investor base. Although these data have their own merits, such as shorter reporting lags, they do not provide an integrated view of the changes in the global demand for government debt across a wide range of countries.

This paper takes a step towards filling this data gap by compiling a comprehensive investor base dataset for advanced economies. To this end, the paper introduces a dataset with the following characteristics: First, a common definition of sovereign debt is used (general government gross debt on a consolidated basis). Second, a common estimation methodology is used to ensure cross-country comparability based on harmonized international data sources, such as the Bank for International Settlements (BIS), IMF, and World Bank. Third, all data are compiled either in face value or adjusted for valuation changes, where appropriate, to track investor transactions as well as holdings. Fourth, foreign investor holdings are estimated separately for the foreign official sector, foreign banks, and foreign nonbanks, in contrast to national data sources that usually classify them under one category ("rest of the world"). Finally, the dataset covers 24 countries that make up 98 
percent of the general government debt of all advanced economies and can, therefore, provide a comprehensive view of the global demand for advanced economy sovereign debt. ${ }^{2}$

\section{Based on this dataset, the paper examines how investors changed their holdings of} advanced economy sovereign debt after the global financial crisis, including during the recent euro area debt turmoil. While recent changes in the sovereign investor base for euro area countries have been widely discussed (Andritzky, 2012; IMF, 2012; Lojsch et al., 2011; Merler and Pisani-Ferry, 2012a), this paper tries to provide a more comprehensive view across all advanced economies in the post-crisis period. In doing so, we also examine how changes in the investor base of euro periphery countries may be linked to the investor flows to other advanced economies ("safe haven flows"). Further, we also analyze how advanced economy banks are changing their exposures to their own government debt.

Finally, the paper constructs risk indicators to assess and monitor the vulnerability of countries to sudden investor outflows. In particular, the paper proposes a frameworksovereign funding shock scenarios (FSS) - to assess a country's ability to manage a sudden outflow of foreign investors by relying more on its local investor base, in particular domestic banks. It also provides two risk indices - investor base risk index (IRI) and foreign investor position index (FIPI) — to assess sovereigns' vulnerability to shifts in investor behavior.

The rest of the paper is organized as follows. Section II discusses the motivation of the paper. Section III describes the methodology and data sources used to compile our investor base estimates. Section IV highlights the main trends we identify in the dataset, in particular in terms of their impact on refinancing risk and domestic financial stability. Section $\mathrm{V}$ describes the risk indicators. The final section examines some of the policy implications of our findings for public debt management, financial stability, and sovereign risk measurement.

\section{Motivation}

Why does the composition of the sovereign investor base matter? There are at least three reasons: shifts in the sovereign investor base can affect (i) governments' borrowing costs; (ii) governments' refinancing risks; and (iii) can create potentially harmful sovereign-bank linkages and threaten domestic financial stability to the extent that domestic banks become highly exposed to own government debt. In addition, the diversity of the investor base can matter for market liquidity and liability management operations in government debt markets.

\section{Borrowing costs}

Shifts in the composition of the investor base can have significant implications for governments' borrowing costs. In the short run, the supply of sovereign debt is set by the government and, therefore, the price (or inversely yield) of debt is set primarily by demand

\footnotetext{
${ }^{2}$ Although the dataset is compiled for advanced economies, the methodology can be extended to emerging markets, with a few modifications. In this paper, we focus on advanced economies to avoid a number of technical issues, such as exchange rate valuation adjustments, and to examine asset allocation decisions of a common class of sovereign debt investors that are traditionally interested in interest-rate risk, not credit risk.
} 
through auctions and other means. Hence, as new investors, such as foreign or institutional investors, join the investor base, demand for government debt can increase (either at the auction or the secondary market) and the government's borrowing costs can decline. Several studies show that an increase in the share of foreign investors or domestic institutional investors in the investor base is associated with lower sovereign bond yields (Andritzky, 2012; De Santis, 2012; Warnock and Warnock, 2009).

\section{Refinancing risk}

At the same time, a rising share of foreign investors in the investor base can heighten governments' refinancing risk. Foreign investors, in particular foreign private investors, could be a less stable source of demand, given the broader pool of assets they can invest in. As a result, they may be less willing to roll over (or more likely to sell) their holdings when the sovereign experiences a confidence shock. Some countries may also be hit by sudden stops in foreign funding simply as a result of increased global risk aversion (Calvo and Talvi, 2005). Regardless of the reason (country-specific or global), a rising share of foreign investors in the investor base can increase the exposure of a sovereign to refinancing risk. This is one reason why public debt managers pay special attention to investor relations, especially with respect to foreign investors (Blommenstein et al., 2011; IMF, 2011a).

\section{Domestic financial stability}

On the other hand, a high share of domestic banks in the investor base may jeopardize domestic financial stability. Domestic banks, being leveraged investors, have the ability to take up significant amounts of government debt, especially when other investors are selling. During the euro area debt turmoil, domestic banks in a number of countries have indeed been significant buyers of government debt when foreign investors have fled the market. However, rising bank holdings of own government debt may pose another type of risk, that is the risk to domestic financial stability stemming from a strong two-way interdependence between the sovereign and domestic bank balance sheets (BIS, 2011; Merler and Pisani-Ferry, 2012b). Specifically, market concerns about sovereign risk could quickly undermine confidence in banks, and thus threaten domestic financial stability, if banks hold large amounts of government debt or their funding costs are closely tied to sovereign yields. In turn, domestic banks may require sovereign support, which could further elevate the sovereign-bank interdependence. Due to these negative feedback loops, a large concentration of government bond holdings in domestic banks is a potential risk to domestic financial stability. In the extreme case, a high interdependence between the sovereign and banks may even lead to a self-fulfilling debt crisis (Adler, 2012). ${ }^{3}$

\section{Other}

\footnotetext{
${ }^{3}$ Apart from these feedback loop effects between banks and their own sovereign, the health of the domestic banking sector could be influenced by cross-border spillover effects, if the domestic banking sector holds a significant amount of debt of high-risk foreign sovereigns.
} 
The composition of the investor base, in particular its diversity, can have other important implications. A diverse investor base, reflecting different investor characteristics in terms of risk tolerance and trading motives, may increase the liquidity of government debt securities in the secondary market (World Bank and IMF, 2001). Markets may better reflect sovereign credit risk with a large and diverse investor base (Ejsing et al. 2012). At the same time, a more concentrated investor base, in terms of the number of creditors holding the debt, may facilitate easier liability management operations in government debt markets (Das, Papaioannou, and Trebesch, 2012).

The focus of the paper is on the implications of changes in sovereign investor base for governments' refinancing risks and domestic financial stability. The first issue (i.e., the relationship between the investor base and sovereign borrowing costs) has been explored in various studies (Bernanke, Reinhart, and Sack 2004; Frankel, 1985; Friedman and Roley, 1980; Warnock and Warnock 2009). ${ }^{4}$ On the other hand, the importance of the other two issues (i.e., the relationship between the investor base and the government's refinancing risk and domestic financial stability), was highlighted only after the recent financial crisis, in particular for advanced economies. Hence, the focus of the paper is on these two issues, which are of particular importance for public debt management and financial sector supervision. Finally, the paper does not deal with diversity of the investor base or debt sustainability issues.

\section{METHODOLOGY FOR SOVEREIGN INVESTOR BASE ESTIMATES}

\section{A. Overview}

This section explains the methodology and data sources used to compile our investor base estimates. The estimates are compiled on a quarterly basis and cover the period from 2004 to 2011 for 24 major advanced economies. The sample covers US\$ 42 trillion of government debt and represents 98 percent of the general government debt of all advanced economies as of end-2011, based on the October 2012 IMF World Economic Outlook (WEO) figures. Table 1 provides the list of countries in our dataset. Table 2 provides a summary of the data sources used in the compilation of our estimates. Figure 1 provides an overview of our estimation methodology.

Table 1. Sample of Countries

\begin{tabular}{cccc}
\hline Australia & Finland & Japan & Slovenia \\
Austria & France & Korea & Spain \\
Belgium & Germany & Netherlands & Sweden \\
Canada & Greece & New Zealand & Switzerland \\
Czech Republic & Ireland & Portugal & United Kingdom \\
Denmark & Italy & Norway & United States \\
\hline
\end{tabular}

\footnotetext{
${ }^{4}$ Recently, there has also been interest in portfolio balance models of government debt to explain how central bank quantitative easing policies are affecting interest rates. Addressing these issues, which requires empirically identifying the demand function for government debt, is beyond the scope of this paper.
} 
Table 2. Summary of Data Sources

\begin{tabular}{|c|c|c|c|c|}
\hline & $\begin{array}{l}\text { Primary Data } \\
\text { Sources }\end{array}$ & $\begin{array}{l}\text { Coverage, } \\
\text { by sector }\end{array}$ & $\begin{array}{c}\text { Coverage, by } \\
\text { instrument }\end{array}$ & Valuation \\
\hline Total Debt 1/ & $\begin{array}{c}\text { Eurostat, Government } \\
\text { Financial Statistics }\end{array}$ & $\begin{array}{c}\text { General } \\
\text { Government }\end{array}$ & $\begin{array}{l}\text { Currency and } \\
\text { Deposits; Loans; } \\
\text { Securities }\end{array}$ & $\begin{array}{c}\text { Country } \\
\text { practices differ } \\
\text { (see Table 4) }\end{array}$ \\
\hline $\begin{array}{l}\text { Foreign } \\
\text { Holders 2/ }\end{array}$ & $\begin{array}{c}\text { IMF/World Bank, } \\
\text { Quarterly External } \\
\text { Debt Statistics (QEDS) }\end{array}$ & $\begin{array}{c}\text { General } \\
\text { Government }\end{array}$ & $\begin{array}{l}\text { Loans and } \\
\text { Securities }\end{array}$ & $\begin{array}{c}\text { Country } \\
\text { practices differ } \\
\text { (see Table 4) }\end{array}$ \\
\hline Foreign Banks & $\begin{array}{l}\text { BIS, International } \\
\text { Banking Statistics }\end{array}$ & $\begin{array}{c}\text { General } \\
\text { Government }\end{array}$ & $\begin{array}{l}\text { Loans and } \\
\text { Securities }\end{array}$ & $\begin{array}{c}\text { Country } \\
\text { practices differ } \\
\text { (see Table 4) }\end{array}$ \\
\hline $\begin{array}{l}\text { Foreign Official: } \\
\text { Foreign Central } \\
\text { Banks 3/ }\end{array}$ & $\begin{array}{c}\text { IMF, Currency } \\
\text { Composition of Official } \\
\text { Foreign Exchange } \\
\text { Reserves (COFER); } \\
\text { IMF, Coordinated } \\
\text { Portfolio Investment } \\
\text { Survey (CPIS) }\end{array}$ & $\begin{array}{c}\text { General } \\
\text { Government }\end{array}$ & Securities & Market value \\
\hline $\begin{array}{l}\text { Foreign Official: } \\
\text { Securities Markets } \\
\text { Program (SMP) }\end{array}$ & $\begin{array}{c}\text { ECB, Eurosystem } \\
\text { Financial Statements }\end{array}$ & $\begin{array}{c}\text { General } \\
\text { Government }\end{array}$ & Securities & $\begin{array}{l}\text { Acquisition } \\
\text { value }\end{array}$ \\
\hline $\begin{array}{l}\text { Foreign Official: } \\
\text { Official Loans }\end{array}$ & $\begin{array}{c}\text { IMF/World Bank, } \\
\text { Quarterly External } \\
\text { Debt Statistics (QEDS) }\end{array}$ & $\begin{array}{c}\text { General } \\
\text { Government }\end{array}$ & Loans & Face value \\
\hline Domestic Banks & $\begin{array}{l}\text { IMF, International } \\
\text { Financial Statistics } \\
\text { (IFS) }\end{array}$ & $\begin{array}{c}\text { General } \\
\text { Government }\end{array}$ & $\begin{array}{l}\text { Loans and } \\
\text { Securities }\end{array}$ & $\begin{array}{c}\text { Country } \\
\text { practices differ } \\
\text { (see Table 4) }\end{array}$ \\
\hline $\begin{array}{l}\text { Domestic Central } \\
\text { Bank }\end{array}$ & $\begin{array}{l}\text { IMF, International } \\
\text { Financial Statistics } \\
\text { (IFS) }\end{array}$ & $\begin{array}{c}\text { General } \\
\text { Government }\end{array}$ & $\begin{array}{l}\text { Loans and } \\
\text { Securities }\end{array}$ & $\begin{array}{c}\text { Country } \\
\text { practices differ } \\
\text { (see Table 4) }\end{array}$ \\
\hline
\end{tabular}

1/ For Australia, Canada, Japan, Korea, New Zealand, and the United States, we rely on national flow of funds data to construct the data series for consolidated general government debt (Table 3).

2/ New Zealand does not provide data to the QEDS, necessitating data extraction from Reserve Bank of New Zealand ("Table D0: New Zealand Government Securities Held for Non-residents").

3/ For the United States, we rely on U.S. Treasury International Capital (TIC) reporting system. 
Figure 1. Summary of Methodology

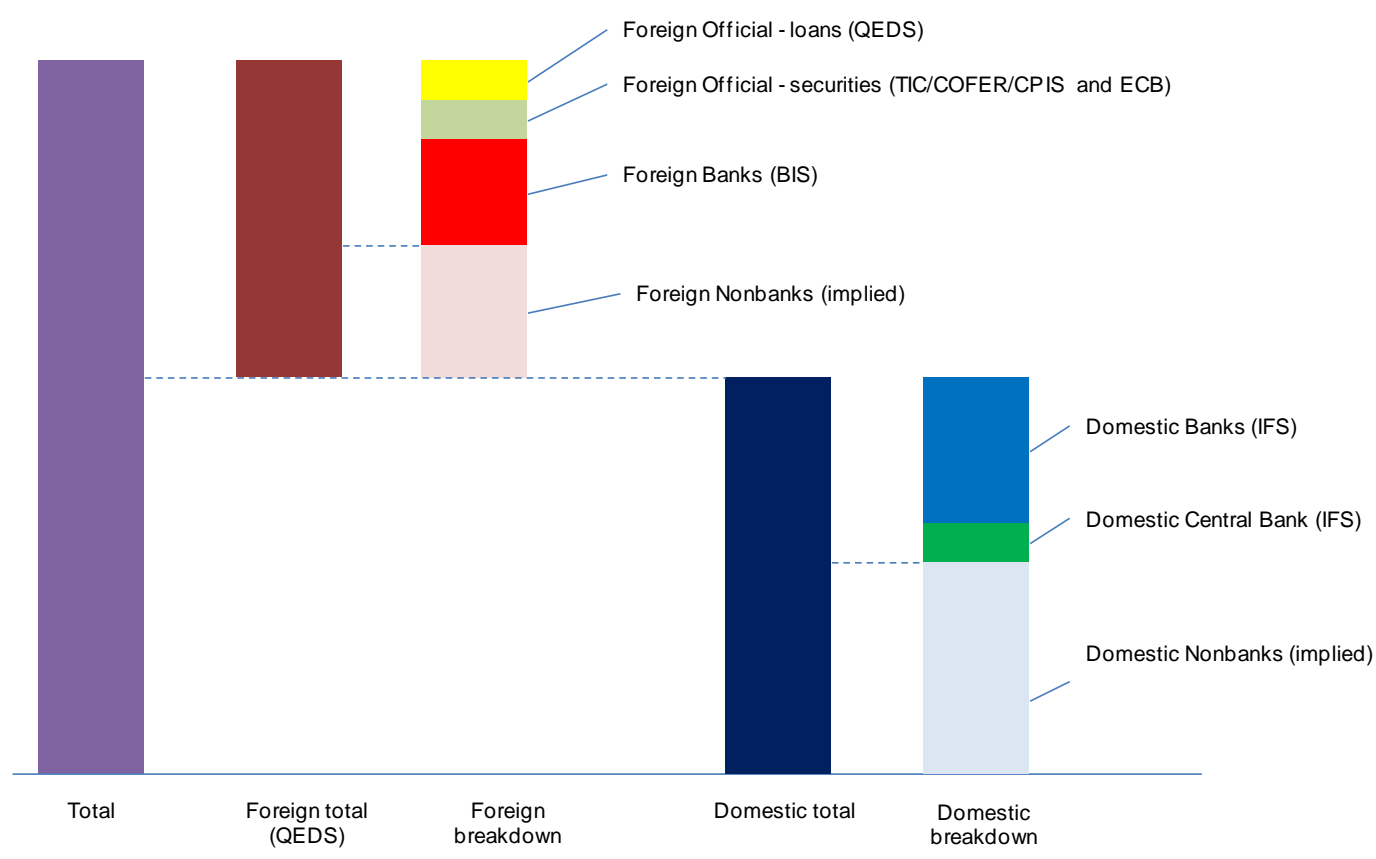

Source: Authors' methodology

Note: Dotted lines lead to calculation of implied values.

Throughout the exercise, we use a common definition of government debt- general government gross debt on a consolidated basis. General government gross debt covers the debt of the central government, local and state governments, and social security funds. When it is consolidated, all intra-governmental holdings, such as central government debt held by social security funds, are netted out. Our definition of government debt includes three types of financial instrument: currency and deposits; securities other than shares; and loans. ${ }^{5}$ This definition does not include other types of government liabilities, such as accounts payable, insurance and pension reserves, or social security obligations. Government liabilities in the form of financial derivatives or government guaranteed debt are not part of government debt either. Finally, all debt figures are expressed in face value and on a gross basis. ${ }^{6}$ For European Union (EU) countries, this definition matches with the definition of "Maastricht debt", for which data are readily available from Eurostat's Quarterly Government Finance Statistics. ${ }^{7}$ For others, they are constructed from national flow of funds data using the same definition of government debt (Table 3).

\footnotetext{
${ }^{5}$ Currency and deposits mainly represent saving certificates and retail bonds that can be redeemed before maturity, and are generally a relatively small share of total debt for most advanced economies. They are usually included in short-term debt unless detailed information is available to make the short-term/long-term attribution.

${ }^{6}$ Although some countries may use the "net debt" concept by subtracting various types of financial assets from gross debt, there is no internationally recognized common definition of net debt.

${ }^{7}$ Norway and Switzerland also provide government debt figures consistent with the definition of "Maastricht debt." The data for Switzerland are on an annual basis, so quarterly figures are interpolated.
} 
We adopt a common definition of debt in order to facilitate international comparability and to avoid institutional differences across countries in intra-governmental relations. Taking general government debt as a whole avoids inconsistencies due to country specific institutions and circumstances. For example, estimates on central government debt alone can be sensitive to intra-governmental transfer arrangements; in some countries, central government borrowing agencies issue securities on behalf of local governments (Netherlands), while in others local governments issue their own debt (U.S.). Similarly, focusing solely on securities would miss the fact that loans are now a large part of the debt stock for a number of advanced economies (Greece, Ireland, and Portugal). Finally, we look at loans and securities together because investors would, in principle, make investment decisions based on the totality of their sovereign exposure, not just the securitized or the marketable part.

\section{Table 3. Construction of General Government Gross Debt on a Consolidated Basis for Non- European Countries, end-2011}

\begin{tabular}{lrrrr}
\hline & $\begin{array}{r}\text { Currency and } \\
\text { deposit }\end{array}$ & Loans & Securities & Total \\
\hline & & (in billions of local currency) & \\
Australia 1/ & 3 & 25 & 461 & 489 \\
Canada 2/ & 5 & 26 & 1,206 & 1,237 \\
Japan 3/ & 0 & 164,123 & 877,657 & $1,041,780$ \\
Korea 4/ & 0 & 7,581 & 401,829 & 409,410 \\
New Zealand 5/ & 0 & 8 & 60 & 67 \\
United States 6/ & 0 & 0 & 12,919 & 12,919 \\
\hline
\end{tabular}

Sources: National authorities and authors' calculations.

1/ Australian Bureau of Statistics, Financial Accounts, Financial Assets and Liabilities of National, State and Local Governments, and Central Borrow ing Authorities (Tables 15, 18, 19). Currency and deposits come from series A3428366R. Loans are calculated as the sum of (i) loans incurred by the national government (A3427856L), excluding those held by state and local governments (A3545161A); (ii) loans incurred by state and local governments (A3430703J and A3428981T), excluding those held by the national government (A3372109A) and central borrow ing authorities (A3362881W and A3367426K); and (iii) loans incurred by central borrow ing authorities (A3429518J and A3428141A), excluding those held by the national government (A3372634X) and state and local governments (A3374662V and A3545157K). Securities are calculated as the sum of (i) bonds issued by the national government (A3429809J and A3431234W), excluding those held by state and local governments (A3366454A) and central borrow ing authorities (A3361453J); (ii) one name paper issued by the national government (A3426527F and A3426221R), excluding those held by state and local governments (A3544923T) and central borrow ing authorities (A3371917F); (iii) bonds issues by state and local governments (A3426545K and A3432266J); (iv) one name paper issued by state and local governments (A3424715C and A3426785W); (v) bonds issues by central borrow ing authorities (A3431996T and A3429233C), excluding those held by the national government (A3369037T) and state and local governments (A3368482W); (vi) one name paper issued by central borrow ing authorities (A3431984J and A3427286W); excluding those held by state and local governments (A3361780T); and (vii) bills of exchange issued by the national government (A3429770K), state and local governments (A3428918A), and central borrow ing authorities (A3426203K). 2/ Statistics Canada, National Balance Sheet Accounts: Book value, Financial Liabilities of Consolidated General Government: currency and deposits (V52224939), loans (V52224940), short-term paper (V52224942), and bonds (V52224943).

3/ Bank of Japan, Flow of Funds, Financial Assets and Liabilities (Major Sectors and Transaction items), General Government Sector: currency and deposits, securities other than shares, and loans.

4/ Bank of Korea, Flow of Funds, Financial Liabilities of General Government Sector: currency \& deposits, securities other than shares, loans, and other foreign claims and debts.

5/ Reserve Bank of New Zealand, Table D2 Ow nership of New Zealand's Government Securities (all government securities on issue excluding those held by public accounts and dependent administrative bodies; accident and superannuation accounts, earthquake commission; and local authorities and public administrative organisations); and Statistics New Zealand, Local Government Statistics.

6/ U.S. Federal Reserve, Flow of Funds, Consolidated Statement for Federal, State, and Local Governments (Table L.105.c).

The investor base for each country's government debt is decomposed into six investor classes - domestic central bank; domestic banks; domestic nonbanks; foreign official sector; foreign banks; and foreign nonbanks. Banks comprise depository corporations other than central banks, based on the definition used in the IMF's International Financial Statistics (IFS). Nonbanks include institutional investors other than banks (insurance companies, 
pension funds, and investment funds), as well as households and non-financial corporations. ${ }^{8}$ The foreign official sector includes foreign central banks and other foreign official creditors. Figure 2 shows the estimated holdings of these investors for our sample countries, as of end2011. Annex I provides the full picture of investor holdings since 2004. Annex II provides a summary of the cumulative purchases of government debt by investor type, highlighting which investors have been absorbing the rise in government debt of advanced economies after the global financial crisis.

Figure 2. Advanced Economies: Holders of Government Debt, end-2011 (percent of total)

Domestic central bank

-Foreign bank

Domesticbank

Foreign central bank

Euro Area

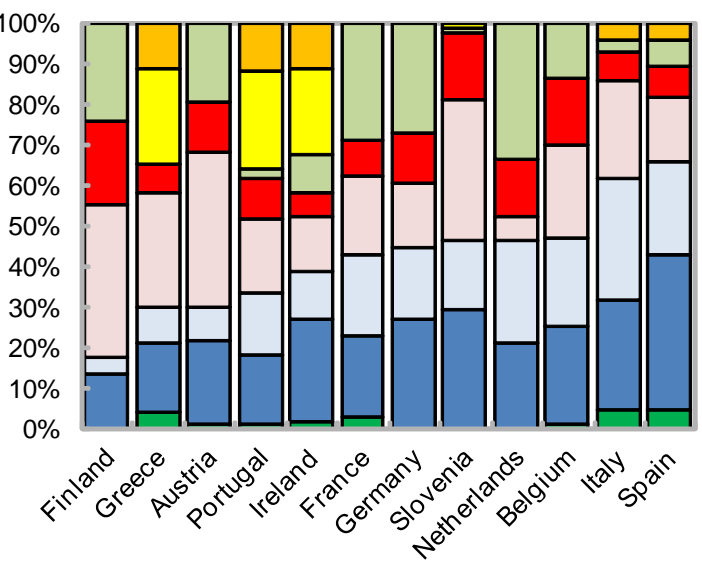

Domestic nonbank

Foreign official loans
Foreign nonbank

SMP_external

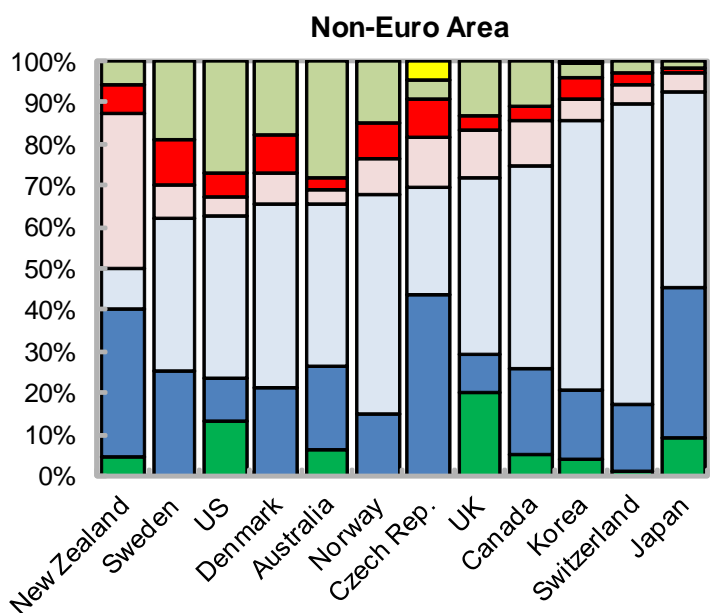

So urce: Authors' calculations.

Note: Government debt indicates general government g ross debt on a consolidated basis, which excludes intergovernmentalholdings. Domestic banks are depository corporations residing in thecountry (IFS definition). Foreign banks are BIS reporting banks residing outside the country. Foreign central bankindicates government debt holdings as foreign exchange reserves. SMP_external indicates SMP holdings of fo reign central banks. Foreign n onbanks and domestic nonbanks are imputed from external and to tal debt.

We ensure that all debt holdings, in particular securities holdings, are compiled either in face value or adjusted for valuation changes, where appropriate. In most international data sources, such as external debt statistics, the BIS international banking statistics, and the IFS, it is recommended that tradable securities are, in principle, valued at market prices. However, it is also recognized that national accounting rules may require different valuation methods. ${ }^{9}$ Based on the metadata available in our data sources, we identify the valuation method used by each country in its reporting, and where appropriate, convert securities holdings in market value to face value (Table 4). Specifically, valuation adjustment for debt securities is done as follows:

\footnotetext{
${ }^{8}$ While household or non-financial corporate holdings of government debt account for a sizable portion of nonbanks in some countries (Italy and U.K.), institutional investors usually make up the bulk of nonbank holdings. At end-2010, assets under management of institutional investors in advanced economies amounted to US\$70 trillion, of which US\$25 trillion belonged to investment funds, US\$23 trillion belonged to insurance companies, and US\$21 trillion belonged to pension funds, according to OECD estimates.

${ }^{9}$ More details on valuation principles for securities can be found in the BIS Guide to the International Banking Statistics; IMF Coordinated Portfolio Investment Survey Guide; IMF External Debt Statistics: Guide for Compilers and Users; and IMF Monetary and Financial Statistics: Compilation Guide.
} 
- $\quad$ For EU countries, the market-to-face value ratio is calculated by comparing the value of outstanding government securities (excluding financial derivatives) in government financial accounts (market value), available from the ECB, with the value of outstanding government securities reported under the Maastricht debt definition (face value), available from Eurostat. Where market and face values are available for the debt holdings of subgroup of investors, we calculate investor-specific market-to-face value ratio (Belgium, Italy, Netherlands, and Portugal). Finally, where transaction data by investor type are available, investor-specific market-to-face value ratios are calculated from estimated face values from transactions (Greece and U.K.).

- $\quad$ For non-EU countries, we use the Barclays Capital Global Treasury Index, which provides both the market and face values of outstanding government debt securities.

Table 4. Valuation of Debt Securities in Various Databases 1/

\begin{tabular}{|c|c|c|c|}
\hline & $\begin{array}{c}\text { Domestic Bank / } \\
\text { Domestic Central Bank }\end{array}$ & Foreign Bank & External debt \\
\hline Data sources & IFS / National Sources & BIS & QEDS \\
\hline Australia & Book value & Book value & Market value \\
Austria & Market value & Book value & Market value \\
Belgium & Book value & Book value & Market value \\
Canada & Book value & Book value & Face value \\
Czech Republic & Book value & N/A & Market value \\
Denmark & Market value & Market value & Market value \\
Finland & Book value & Book value & Market value \\
France & Book value & Book value & Market value \\
Germany & Book value & Book value & Market value \\
Greece & Book value & Market value & Market value \\
Ireland & Book value & Book value & Face value \\
Italy & Book value & Book value & Market value \\
Japan & Book value & Book value & Market value \\
Korea & Book value & Book value & Market value \\
Netherlands & Book value & Book value & Market value \\
New Zealand & Book value & N/A & Face value \\
Portugal & Book value & Book value & Market value \\
Norway & Book value & Book value & Market value \\
Slovenia & Book value & N/A & Market value \\
Spain & Book value & Book value & Market value \\
Sweden & Book value & Book value & Market value \\
Switzerland & Book value & Book value & Market value \\
United Kingdom & Market value & Market value & Market value \\
United States & Book value & Book value & Face value \\
\hline
\end{tabular}

Sources: IMF Dissemination Standards Bulletin Board; BIS Guidelines to International Locational Banking Statistics; and national authorities.

$1 /$ "Book value" indicates an accounting treatment that is based on national accounting standards, which, generally, values the trading portfolio at market value and the banking portfolio at nominal value.

Finally, all statistics provided in U.S. dollars are converted into respective national currencies. In particular, BIS international banking statistics and IMF/World Bank Quarterly External Debt Statistics (QEDS) are converted into the respective national currencies using end-quarter exchange rates obtained from the IFS. 
Our estimates rely on a number of broadly compatible international data sources. Our primary data sources are the BIS International Locational Banking Statistics, the IMF International Financial Statistics (IFS), and the IMF/World Bank QEDS. All the data sources are based on the same residency principle of the investor, include comparable definitions of general government, and use similar definitions of debt instruments. At the same time, as discussed earlier, the valuation of securities in these data sources may differ, requiring appropriate adjustments.

\section{B. Estimation Methodology for Each Investor Type}

\section{Below we discuss in more detail how we calculate the holdings of various investors:}

\section{Foreign holdings}

Foreign holdings are estimated from the IMF/World Bank QEDS database. The QEDS database, launched in 2004, brings together external debt statistics that are compiled by countries that subscribe to the IMF's Special Data Dissemination Standard (SDDS) to provide access to comparable and standardized external debt data. The data are made available on a quarterly basis. ${ }^{10}$ Using this database, we estimate foreign holdings as the sum of (i) general government securities (money market instruments; bonds and notes) held externally; and (ii) general government loans held externally, consistent with the definition of debt used in the paper. Since debt securities are recorded at market value in QEDS (except for Canada, Ireland, and the U.S.), they are converted into face value based on the valuation adjustment discussed earlier (Tables 2 and 4). For New Zealand, which does not provide data to the QEDS, external debt estimates are obtained from the Reserve Bank of New Zealand.

\section{Foreign official sector holdings}

Foreign official sector holdings consist of (i) government securities held by foreign central banks as foreign exchange reserves; (ii) government securities held by foreign central banks within the Eurosystem as part of the Securities Markets Program (SMP); and (iii) foreign official loans. To be consistent with the residency principle applied throughout this paper, the second item includes only SMP holdings of foreign central banks (i.e. excluding domestic central bank holdings of own government securities as part of the SMP).

\section{Foreign central bank holdings}

Foreign central bank holdings are estimated in the following manner: For the United States, we use the U.S. Treasury International Capital (TIC) reporting system because it provides the most reliable estimate of foreign official holdings of U.S. government debt, in particular U.S.

\footnotetext{
${ }^{10}$ External debt statistics in QEDS can sometimes differ from corresponding figures in national flow of fund (FoF) data. We stick to external debt statistics because these are based on a common compilation methodology (IMF's External Debt Statistics: Guide for Compilers and Users published in 2003), while compilation for FoF data differs across countries. Furthermore, external debt statistics do not include financial derivatives in debt statistics, in line with our definition of government debt, while national FoF data may include them.
} 
Treasury securities. ${ }^{11}$ For other countries, foreign official holdings are estimated from IMF's Currency Composition of Official Foreign Exchange Reserves (COFER) and Coordinated Portfolio Investment Survey (CPIS) databases. In particular:

- $\quad$ COFER database. As of end-September 2012, 34 advanced and 109 emerging and developing economies report the currency composition of their foreign exchange reserves to the IMF COFER database. In terms of size, these represent about half of worldwide foreign exchange reserves. COFER provides quarterly data on the currency breakdown of these "allocated" reserves into five major currencies (USD, EUR, GBP, JPY, and CHF) and "other currencies." We assume that the currency composition of the "unallocated" part is the same as the "allocated" part. We also assume that 80 percent of foreign exchange reserves in a currency consists of government securities of the country/countries issuing that currency. ${ }^{12}$ With these assumptions, we estimate foreign central bank holdings of government securities for Japan, Switzerland, and the U.K., and, with additional information from the CPIS database (see below), for the euro area and other advanced economies.

- $\quad$ CPIS database. As of end-September 2012, more than 100 economies report to the IMF CPIS database. Table 6 of the CPIS database reports the residency of the issuer of debt securities held as reserve assets (including those held by international organizations). We use this information to distribute the COFER data for EUR and "other currencies" to individual euro area and other advanced economies. Table 5 shows this calculation for end-2011.

A final issue regarding our foreign central bank estimates is valuation. The TIC data are a hybrid of market and face value: foreign holdings of Treasury bonds are reported at market value, while those of Treasury bills are reported at face value. Hence, we apply a valuation adjustment only on the Treasury bond component of TIC data. The valuation adjustment for that component is calculated from face value of long-term U.S. government debt securities held by non-residents (available from QEDS) and market value of long-term U.S. Treasury securities held by foreigners (available from TIC). For COFER/CPIS data, which are reported at market value in line with IMF recommendations for reporting of foreign exchange reserves, we apply the same valuation adjustment applied on total foreign holdings.

\footnotetext{
${ }^{11}$ While TIC data cover only U.S. Treasury securities, U.S. Federal Reserve flow of funds data indicate that foreign holdings of local and state government debt are relatively small (less than US\$90 billion).

${ }^{12}$ Based on IMF Data Template on International Reserves and Foreign Currency Liquidity and IMF CPIS data during 2008-10, we estimated that, on average, 80 percent of foreign exchange reserves consisted of national debt securities, while the rest comprised currency and deposits with foreign banks and central banks, debts of international institutions, and equities. We also checked this assumption for Spain, which used to provide data on foreign central bank holdings of national debt, and latest official estimates were in line with our estimates.
} 
Table 5. Estimation of Foreign Central Bank Holdings of Government Debt, end-2011

(in billions of U.S dollar)

\begin{tabular}{|c|c|c|c|c|c|}
\hline & Countries & $\begin{array}{l}\text { Total Foreign Exchange } \\
\text { Reserves (COFER) 1/ }\end{array}$ & $\begin{array}{l}\text { Sovereign Debt in Foreign } \\
\text { Exchange Reserves } 2 /\end{array}$ & $\begin{array}{l}\text { Country Share } \\
\text { (CPIS) }\end{array}$ & $\begin{array}{l}\text { Country } \\
\text { Allocation }\end{array}$ \\
\hline \multirow[t]{13}{*}{ Euro } & & 2,553 & 2,042 & $99.4 \%$ & 2030 \\
\hline & Austria & $\ldots$ & $\ldots$ & $3.2 \%$ & 66 \\
\hline & Belgium & $\ldots$ & $\ldots$ & $3.0 \%$ & 62 \\
\hline & Finland & $\ldots$ & $\ldots$ & $1.6 \%$ & 33 \\
\hline & France & $\ldots$ & $\ldots$ & $34.5 \%$ & 705 \\
\hline & Germany & $\ldots$ & $\ldots$ & $39.8 \%$ & 814 \\
\hline & Greece & $\ldots$ & $\ldots$ & $0.0 \%$ & 0 \\
\hline & Ireland & $\ldots$ & $\ldots$ & $0.9 \%$ & 18 \\
\hline & Italy & $\ldots$ & $\ldots$ & $3.5 \%$ & 72 \\
\hline & Netherlands & $\ldots$ & $\ldots$ & $9.4 \%$ & 191 \\
\hline & Portugal & $\ldots$ & $\ldots$ & $0.2 \%$ & 4 \\
\hline & Slovenia & $\ldots$ & $\ldots$ & $0.0 \%$ & 0 \\
\hline & Spain & $\ldots$ & $\ldots$ & $3.2 \%$ & 64 \\
\hline \multirow[t]{9}{*}{ Others } & & 546 & 437 & $94.7 \%$ & 414 \\
\hline & Australia & $\ldots$ & $\ldots$ & $35.9 \%$ & 157 \\
\hline & Canada & $\ldots$ & $\ldots$ & $31.2 \%$ & 136 \\
\hline & Czech Rep. & $\ldots$ & $\ldots$ & $0.0 \%$ & 0 \\
\hline & Denmark & $\ldots$ & $\ldots$ & $7.8 \%$ & 34 \\
\hline & Korea & $\ldots$ & $\ldots$ & $3.1 \%$ & 14 \\
\hline & New Zealand & $\ldots$ & $\ldots$ & $0.8 \%$ & 3 \\
\hline & Norway & $\ldots$ & $\ldots$ & $5.2 \%$ & 23 \\
\hline & Sweden & $\ldots$ & $\ldots$ & $10.6 \%$ & 46 \\
\hline
\end{tabular}

Securities Market Program (SMP) holdings

Euro area government securities held by the Eurosystem central banks for the Securities Market Program (SMP) are relevant for a number of countries (Greece, Ireland, Italy, Portugal, and Spain). The total size of SMP, as a separate item from foreign exchange reserves, can be obtained from the ECB (Consolidated financial statements of the Eurosystem: Asset item 7.1. Securities held for monetary policy purposes). We estimate the country composition of SMP, which is not publicly disclosed, assuming that SMP purchases were made in proportion to the outstanding Maastricht debt of SMP countries. In addition, we estimate the composition of SMP holdings within the Eurosystem by assuming that national central banks participated in the bond purchases in line with their contribution to the capital base of the ECB. Finally, we assume that SMP initially targeted Greece, Ireland, and Portugal (starting from 2010Q2), and then Italy and Spain (staring from 2011Q3). Regarding valuation, since SMP holdings are recorded on a cost basis in the financial statements of the Eurosystem, we apply our valuation adjustment to estimate the face value of these holdings.

\section{Foreign official loans}

Foreign official loans can include official loans from other countries or multilateral loans from international financial institutions (IFIs). In this case, they include EU/IMF program loans for Greece, Portugal, and Ireland after 2010 and project loans for Czech Republic, Greece, Korea, and Slovenia from IFIs, such as the European Investment Bank (EIB) and the 
World Bank. We rely on external loan statistics in QEDS to capture both types of loans for these countries. ${ }^{13}$

\section{Foreign bank holdings}

Foreign bank holdings are estimated primarily from BIS International Locational Banking Statistics. Banks resident in 43 countries currently provide these statistics to the BIS (a list of BIS reporting banks is available on the BIS website on Guidelines to the International Locational Banking Statistics). These statistics provide creditor-side information on BIS reporting banks' claims on non-resident borrowers, consistent with the residency principle of external debt statistics. However, they do not provide information on the share of external claims on the government sector versus other nonbank borrowers. To address this data limitation and estimate this share, we use information from the BIS International Consolidated Banking Statistics (on an immediate borrower basis). In particular, foreign banks' holdings of government debt are estimated as follows:

$$
\text { Foreign bank holdings }=\text { Locational claims on nonbank sector } * \alpha
$$

Where:

Locational claims on the nonbank sector = External positions of reporting banks vis-à-vis, nonbank sector (BIS Locational Banking Statistics Table 6B).

$\alpha=$ Total international claims on public sector on an immediate borrower basis (BIS Consolidated Banking Statistics Table 9A:G) divided by the sum of total international claims on public sector on an immediate borrower basis and nonbank private sector on an immediate borrower basis (BIS Consolidated Banking Statistics Tables 9A:G and 9A:H, respectively).

While claims on an immediate borrower basis are most comparable to our measure of external debt, the use of Consolidated Banking Statistics in the calculation of the share parameter does not fully comply with the residency principle used in this paper. However, in countries with limited international banking business, there is often little difference between external debt owed to banks based on locational statistics and the same variable based on the international component of consolidated statistics (McGuire and Wooldridge, 2005).

Regarding valuation, BIS recommends that banks report their holdings of loans at face value and securities at market value. However, BIS also recognizes that national accounting rules may require different valuation methods for debt securities. In particular, country practices often make a distinction between the banking book and trading book portfolios for securities holdings, in which the banking book is generally valued at cost or face value and the trading book is valued at market value (a summary of reporting practices by reporting country is available on the BIS website for Guidelines to the International Locational Banking Statistics). This presents a challenge for valuation adjustment, because the exact share of debt

\footnotetext{
${ }^{13}$ For other countries, foreign official loans are negligible or nonexistent. Only for Norway, external loans are large, but those mainly represent repurchase agreements of the Government Pension Fund (SPU) with foreign financial institutions. These are recorded as liabilities of the SPU and hence the general government. The volume of these operations was reduced significantly after the crisis, in particular in 2011.
} 
securities classified in each of these two categories is unknown. However, data provided by the 2011 European Banking Authority stress tests indicate that the share of major European banks' sovereign exposures in the trading book is only about 12 percent (IMF, 2011b). We believe that this may also be broadly reflective of non-European banks. As a result, instead of making an ad-hoc valuation adjustment on BIS statistics, we report them as they are, since that would be more appropriate for the loan portfolio as well as the debt securities classified under the seemingly larger banking book.

\section{Foreign nonbank holdings}

Foreign nonbank holdings are estimated as the difference between total foreign holdings and the holdings of the foreign official sector and foreign banks.

\section{Domestic investor holdings}

Domestic investor holdings are estimated as the difference between total debt and foreign debt holdings.

\section{Domestic central bank and domestic bank holdings}

Domestic central bank and domestic bank holdings of government debt are obtained from the IFS, based on gross claims of monetary authorities and "other depository corporations" (IFS definition) on general government, respectively. For a number of countries that do not report these statistics to the IFS, data are collected from national sources (Australia, Canada, Korea, New Zealand, Norway, Switzerland, and U.K.). ${ }^{14}$

In terms of valuation for domestic banks, the treatment is similar to foreign banks. IFS compilation guidelines recommend reporting of bank loans at face value and security holdings at market value. However, country practices differ (Table 4), in particular, similar to BIS statistics, most countries report IFS statistics based on national accounting standards ("book value"), which usually values securities in the trading portfolio at market value and securities in the banking book portfolio at face value. Hence, similar to our treatment of BIS statistics, we do not apply a valuation adjustment on IFS statistics, except for countries that report all securities holdings at market value (Austria, Denmark, and United Kingdom).

\section{Domestic nonbank holdings}

Domestic nonbank holdings are estimated as the difference total domestic holdings and the holdings of domestic banks and the central bank.

\footnotetext{
${ }^{14}$ Specifically, we use the following sources for these countries: Australia (Australian Bureau of Statistics, Flow of Funds), Canada (Bank of Canada, Chartered Bank Balance Sheets), Korea (Bank of Korea, Flow of Funds), New Zealand (Reserve Bank of New Zealand, Table D2), Norway (Statistics Norway), Switzerland (Swiss National Bank, Banks in Switzerland), and United Kingdom (Bank of England, MFI Consolidated Balance Sheets). The data for Switzerland are on an annual basis, so quarterly figures are interpolated.
} 


\section{Robustness Checks and Adjustments}

\section{We undertook the following tests to check the robustness of our estimates, in particular for domestic nonbanks and foreign nonbanks, which are calculated as residuals in our methodology:}

\section{Comparison with national data}

If countries publish comprehensive data on holders of government debt, such data can be used for testing the robustness of our estimates. An exact comparison often turns out to be difficult, because national data vary in terms of sector (central or general government), instrument (securities or total debt), and/or valuation (face or market value). Despite these limitations, we compared our estimates with national data for 12 advanced economies. ${ }^{15}$ For countries that provide the national data for general government at face value, we were able to do a consistency check. In all cases, we found that our estimates, including for domestic nonbanks, were in line with the national data.

\section{Comparison with ECB statistics on euro area institutional investors}

For euro area countries, we compared our estimates of total nonbank holdings (domestic and foreign) with ECB's Insurance Corporations and Pension Funds Statistics and Investment Fund Statistics ("ECB data"). This check is important because foreign nonbanks account for a significant share of the investor base particularly in euro area countries (Figure 2). Our comparison suggests that 70 percent of our domestic and foreign nonbank estimates for euro area countries can be explained by the ECB data (the remaining part most likely reflects noneuro area holdings as well as domestic household and non-financial corporate holdings, which are not in the ECB data).

\section{Basic consistency checks}

Finally, we checked the following basic identities. First, we checked whether foreign central bank holding are lower than total foreign holdings of debt securities. This turns out to be the case except for two cases (Australia and Ireland) for several quarters. We adjust these estimates to comply with the general trend in total foreign holdings of debt securities. Second, we check whether foreign bank holdings are less than the difference between total foreign holdings and foreign official holdings. This turns out to be the case except for four cases (Australia, Ireland, Korea, and Switzerland) for several quarters. We adjust these estimates such that the difference between total foreign holdings and foreign official holdings is distributed between foreign banks and foreign nonbanks in line with the ratio in previous quarters for each country. Finally, we check and confirm that domestic nonbank estimates are positive.

\footnotetext{
${ }^{15}$ The national data for these countries have been recently collected into a database and made publicly available by Bruegel ("Bruegel database of sovereign bond holdings"), as described in Merler and Pisani-Ferry (2012a).
} 


\section{Limitations and Extensions}

\section{Investor Holdings}

Although our estimates of investor holdings are based on an internationally comparable method, like all estimates, they have a number of limitations. These limitations, which are mainly due to data constraints, include:

- Foreign central bank holdings. The currency breakdown in COFER data covers only about half of all foreign exchange reserves (we assume the same composition for the other half). Also, we assume foreign exchange holdings in a currency mainly reflect government debt securities of the country/countries issuing that currency.

- SMP. Country decomposition of SMP holdings, as well as its distribution among Eurosystem central banks, is not publicly disclosed. As a result, we make our own estimates based on simplifying assumptions. Our estimates are broadly in line with market estimates, but actual figures may be somewhat different.

- Foreign banks. Our foreign bank estimates partially rely on BIS consolidated banking statistics to gather the share of claims on government within total nonbank claims, as this information is not provided by BIS locational statistics. Effectively, this means our foreign bank estimates may be somewhat overstated for countries with large international financial centers. In a number of such cases, we have made adjustments to our foreign banks holdings, as explained in Section III.C.

- Foreign and domestic nonbanks. Foreign and domestic nonbanks are calculated as implied variables in our method, and, as residuals, may include measurement errors. Foreign nonbanks may include holdings of foreign banks residing in countries that do not report locational banking statistics to the BIS (e.g. China, Russia), although these are likely to be a relatively small share of the cross-border assets of banks globally.

\section{Investor Transactions}

While our dataset is primarily about tracking investor holdings, it can also be used to gather information about investor transactions. In general, changes in investor holdings between two periods are due to (i) transactions; (ii) price revaluations; (iii) exchange rate changes (in the case of instruments denominated in currencies other than the local currency); or (iv) statistical reclassifications. Regarding our dataset, we believe issues related to (ii), (iii), and (iv) are relatively minor, and, as such, changes in our estimate of investor holdings reflect mainly investor transactions.

\section{However, a few caveats are in order:}

- Price revaluations. Since our estimates are compiled at face value, or converted to face value as appropriate, this issue is, in principle, already addressed by the way we construct our estimates. However, our valuation adjustments should only be seen as a top-down approximation of actual price revaluations in individual portfolios (more 
accurate estimates would require security-by-security price information). At the same time, in a number of cases when data are available, we tailor our valuation adjustment to different investor classes reflecting differences in the maturities of their holdings, as well as different valuation practices used by countries in different data sources.

- Exchange rate changes. Although this is an important issue, in general, we believe it does not pose a significant problem for our sample of advanced economies because most, if not all, of their outstanding debt is denominated in local currency ( 80 percent or more as of end-2011).

- Statistical reclassifications. We are aware of a few important cases of statistical reclassifications in our data sources: For Italy, domestic banks in IFS include a large public financial institution (Cassa Depositi e Prestiti) starting from 2006. The list of BIS reporting banks changed significantly in 2008-09, especially as some large U.S. nonbanks became banks. Canadian banks adopted the International Financial Reporting Standards (IFRS) in 2011.There could be other cases. ${ }^{16}$

\section{Investor Holdings by Country of Origin}

Finally, our data can be extended to estimate the country of origin of investor holdings. While we do not directly address this issue in this paper, we can also make rough estimates of the country of origin of investments in the general government debt markets using our dataset and the CPIS database on portfolio holdings. For that, we assume that the country of origin of general government debt investors is in line with the country of origin of all external debt holders. The higher the percentage of government debt in external debt, the more plausible this assumption is and the more reliable our method. For illustration, Figure 3 shows country decompositions for investors of general government debt for Greece and Japan, where this assumption should hold well, as government debt in external debt is more than 90 percent for these countries. Examining investors' country of origin can help in assessing spillover channels (e.g. euro area holdings of Greek debt), as well as emerging financial linkages between countries (e.g. Chinese investment in Japan). ${ }^{17}$

\footnotetext{
${ }^{16}$ A more comprehensive list of statistical reclassifications can be found directly from our data sources.

${ }^{17}$ At the same time, these estimates cannot attribute country origin with complete accuracy, in particular if a security is purchased by a foreign investor and held in a custodial account in another country, say, an offshore center. Put differently, these estimates reflect exposures on an immediate borrower, not ultimate risk, basis.
} 
Figure 3. Foreign Holdings of Government Debt by Country of Origin, 2004-11 1/ 2/
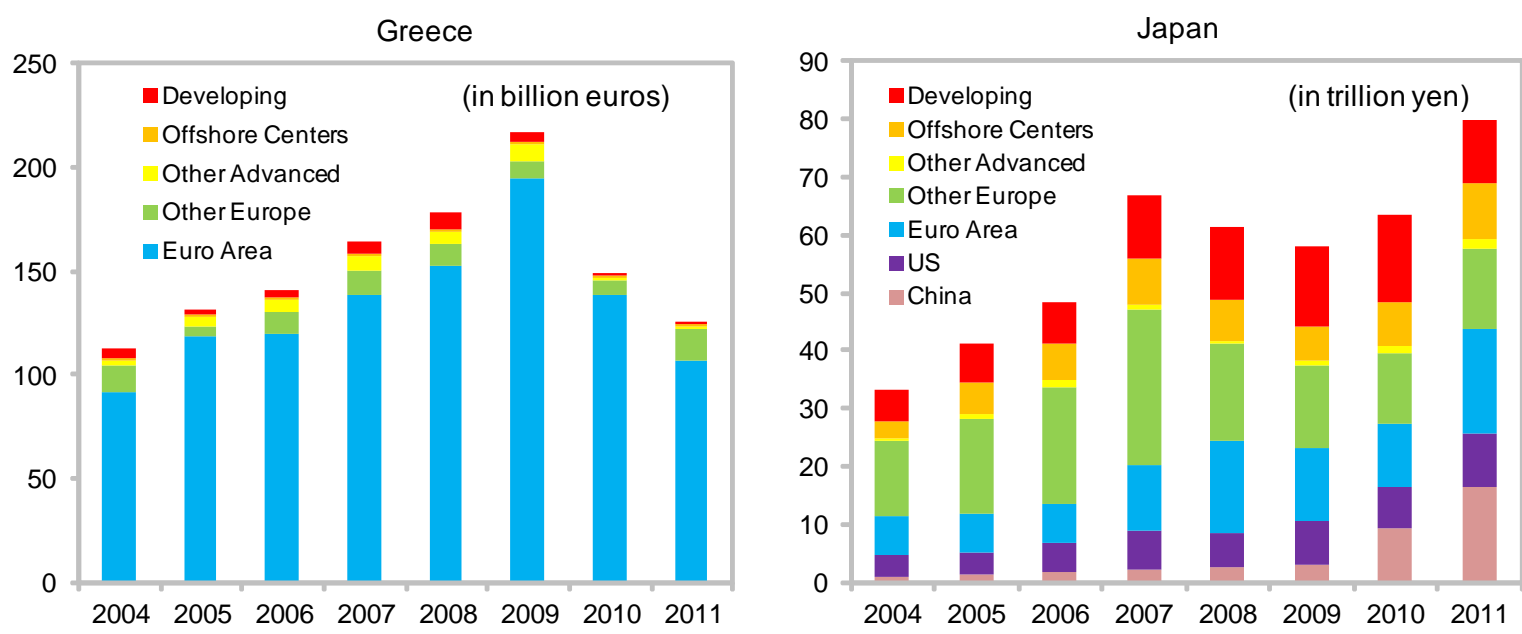

Sources: IMF CPIS and authors' calculations.

1/ Excluding foreign official loans and SMP holdings of fo reign central banks.

2/ Regional groups are based on country classifications of BIS international banking statistics.

\section{Key Trends in The Post-Crisis Period}

In this section, we explore how demand for advanced economy sovereign debt has changed after the global financial crisis. In particular, we explore two main questions based on the issues raised in Section II: (i) How did foreign demand for government debt, and the related refinancing risk, change for advanced economies? (ii) How did changes in demand from domestic banks for own government debt affect bank-sovereign linkages and what are the implications for domestic financial stability? More specifically:

\section{Government refinancing risk}

- Once government debt of some advanced economies lost the perception of being riskfree, how did foreign investors change their portfolio allocations? Which countries, both in the euro area and the non-euro area, had large inflows and outflows?

- Were there differences among foreign investors in their portfolio reallocation? Specifically, how did the investment decisions of foreign central banks, foreign banks, and foreign nonbanks vary?

\section{Domestic financial stability}

- In countries where foreign demand dried up, how did domestic investors respond? Were there differences between domestic banks and nonbanks in their ability to "take up the slack"? 
- $\quad$ More generally, for all advanced economies, how is domestic banks' demand for own government debt changing in the post-crisis period? Are there signs of rising sovereign-bank linkages? What are the implications for domestic financial stability?

While examining these questions, we focus on two separate but related episodes in the postcrisis period: (i) the global financial crisis (2008-09), and (ii) the euro area debt turmoil that started in 2010. Where appropriate, we also group countries to draw out common trends beyond specific country circumstances (Box 1).

\section{A. How Did Foreign Demand Change?}

The first issue we explore in this section is how the foreign demand for advanced economy sovereign debt has changed in the post-crisis period. For the purposes of this section, foreign demand includes foreign banks, foreign nonbanks, and foreign central banks only. Other foreign holdings, in particular foreign official loans and SMP holdings, are not included as these mainly reflect responses to the changing foreign demand environment.

Our data suggest that the share of foreign investors in the investor base has continued to rise for most advanced economy sovereigns outside the high-spread euro area. Aggregate foreign ownership of advanced economy sovereign debt more than doubled from US\$ 5 trillion to US\$ 12 trillion between 2004 and 2011, driven by large purchases by foreign central banks and foreign nonbanks (Figure 4). Foreign bank ownership, on the other hand, remained relatively unchanged at around US $\$ 2$ trillion. As a result, in many countries, foreign banks now account for a declining share of government debt markets. At the same time, through the entire sample period (2004-11), we find that the average share of foreign investors in the investor base of advanced economy sovereign debt increased from 50 to 62 percent for the low-spread euro area countries, from 20 to 31 percent for the "other advanced economies", and from 14 to 21 percent for the traditional reserve countries. The foreign share in total debt of high-spread euro area countries largely stopped rising at end-2009, and then declined from 60 percent to 35 percent during the euro area debt turmoil. Figure 5 provides more details on change in the foreign ownership for individual countries in our sample.

Figure 4. Advanced Economies: Foreign Investors as an Investor Class, 2004-11
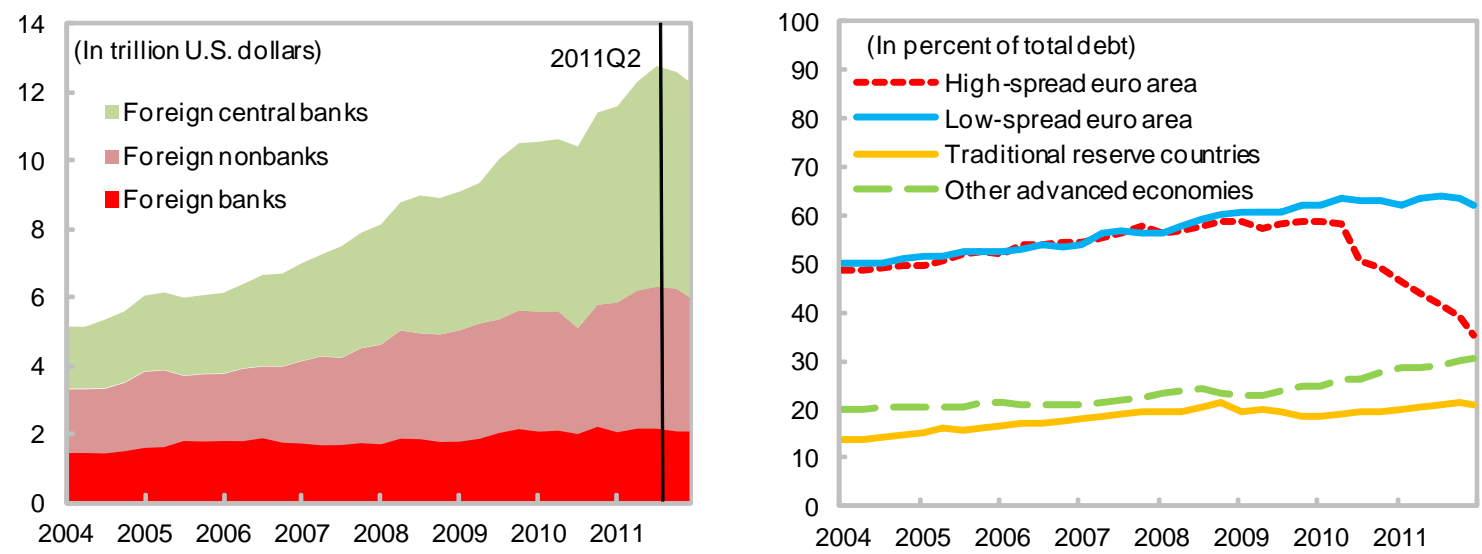

Source: Authors' calculations.

1/Excluding fo reign official loans and SMP holdings of fo reign central banks. 


\section{Box 1. Country Groups}

Four groups among advanced economies in our sample are constructed along the following dimensions: (i) exchange rate regime (independent or currency union); (ii) reserve currency status, and (iii) perceived credit risk in 2011. In particular:

High-spread euro area includes euro area countries identified by the IMF in the April 2012 GFSR as having sovereign CDS spreads of more than 200 basis points as of August 2011 (Belgium, Greece, Ireland, Italy, Portugal, and Spain). Although spreads for Belgium have come down in 2012, it is included in this group as our analysis is mainly about trends until end-2011. Together, these countries account for nearly half of the euro area government debt market and 11 percent of the total advanced economy sovereign debt outstanding, at end-2011.

Low-spread euro area includes the other euro area countries in our sample (Austria, Germany, France, Finland, Netherlands, and Slovenia). Except for Slovenia, all were rated AAA by at least two out of the three major credit rating agencies, as of end2011. This group accounts for 14 percent of the total advanced economy sovereign debt outstanding.

Traditional reserve countries include non-euro area countries that have traditionally enjoyed reserve currency status (Japan, Switzerland, United Kingdom, and United States). These countries have deep and liquid markets, attracting large demand from foreign central banks; as a result, they are traditional beneficiaries from flight to safety. They represent 68 percent of total advanced economy sovereign debt outstanding.

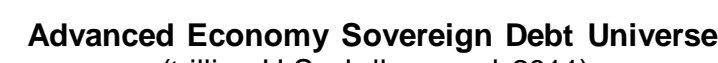
(trillion U.S. dollars, end-2011)

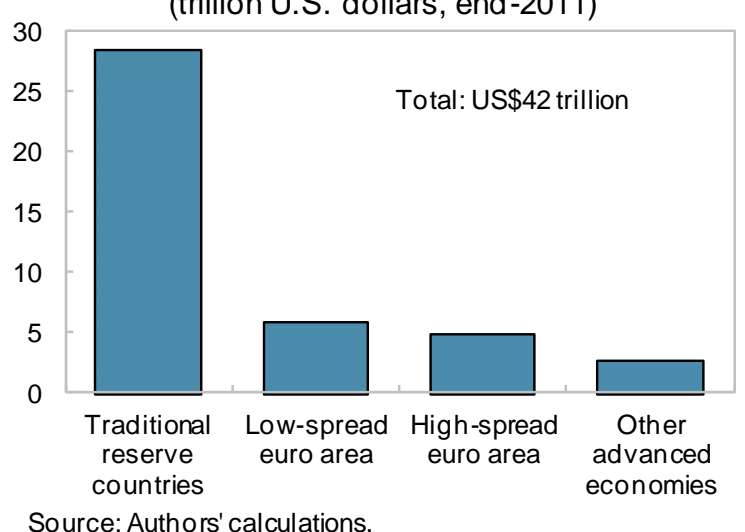

Other advanced economies includes the remaining countries in our sample (Australia, Canada, Czech Republic, Denmark, New Zealand, Norway, Korea, and Sweden), some of which have recently been seen as "new safe havens." They represent 6 percent of total advanced economy sovereign debt outstanding.

Selection of Country Groups for Advanced Economies, end-2011

\begin{tabular}{cccc}
\hline $\begin{array}{c}\text { High-spread euro } \\
\text { area }\end{array}$ & $\begin{array}{c}\text { Low-spread euro } \\
\text { area }\end{array}$ & $\begin{array}{c}\text { Traditional reserve } \\
\text { countries }\end{array}$ & $\begin{array}{c}\text { Other advanced } \\
\text { economies }\end{array}$ \\
\hline Belgium & Austria & Japan & Australia \\
Greece & Finland & Switzerland & Canada \\
Ireland & France & United Kingdom & Czech Republic \\
Italy & Germany & United States & Denmark \\
Portugal & Netherlands & & Korea \\
Spain & Slovenia & & New Zealand \\
& & & Norway \\
& & & Sweden \\
\hline
\end{tabular}

Sources: April 2012 GFSR and authors. 
Figure 5. Advanced Economies: Foreign Share in Government Debt Stock, 2004-11 1/
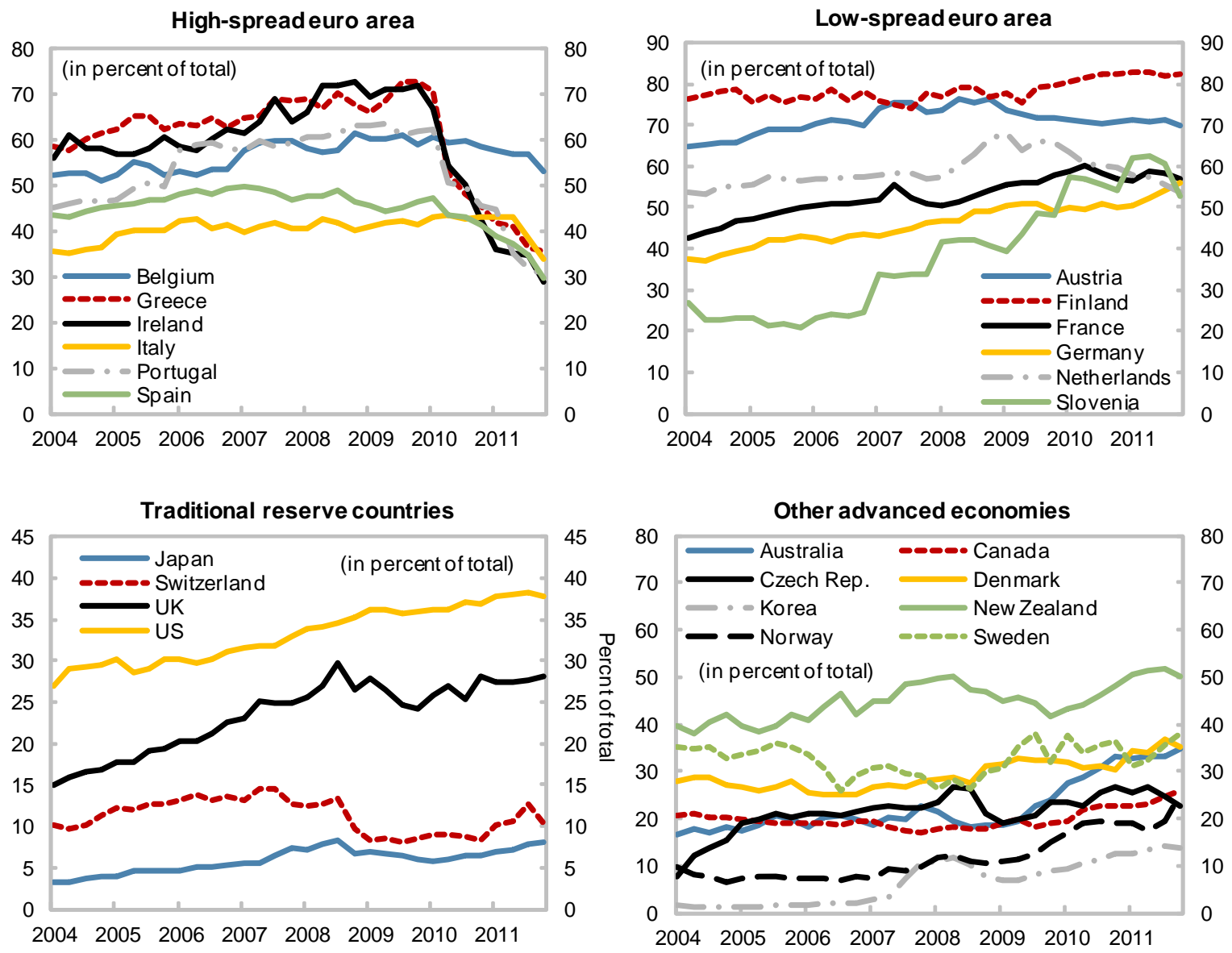

Source: Authors' calculations.

1/ Excluding foreign official loans and SMP holdings of foreign central banks. For Norway, excluding all external loans.

\section{A distinction can be made as to how foreign investors changed their holdings during the global financial crisis (2008-09) and the euro area debt turmoil (starting in 2010).}

Figure 6 shows the estimated investment flows of foreign investors since 2008 across our entire sample. The significance of the flows for each country is indicated by different colors based on z-scores. ${ }^{18} \mathrm{Z}$-scores indicate the degree of fluctuation in investment flows from the viewpoint of each country's historical average. The figure shows that, during the global financial crisis (2008-09), foreign investors increased their holdings of virtually all advanced economy sovereign debt (except for Czech Republic, Japan, Korea, and Switzerland), reflecting the perceived risk-free status of most advanced economy sovereign debt during that time. In the later period, however, foreign investors seem to have taken a much more differentiated view across advanced economy sovereigns, with some countries significantly gaining and some losing demand from foreign investors. The figure also shows how quickly

\footnotetext{
${ }^{18} \mathrm{Z}$-scores are defined as the distance from the mean, measured in units of the standard deviation. Specifically, we calculate z-scores for each observation, based on the 4-quarter moving average of foreign investor flows. The mean and the standard deviation are calculated for each country, using an expanding window starting from 2004Q1, in line with the sudden stop identification methodology of Calvo et al (2004).
} 
foreign investors can change sentiment. For example, foreign investors were net buyers of the sovereign debt of Greece, Ireland, and Portugal up until 2010Q1.

Figure 6. Advanced Economies: Foreign Net Purchases and Sales of Government Debt

\begin{tabular}{|c|c|c|c|c|c|c|c|c|c|c|c|c|c|c|c|c|}
\hline & 2008Q1 & $2008 \mathrm{Q} 2$ & $2008 Q 3$ & $2008 \mathrm{Q} 4$ & 2009Q1 & $2009 \mathrm{Q} 2$ & $2009 Q 3$ & 2009Q4 & 2010Q1 & 2010Q2 & $2010 Q 3$ & $2010 \mathrm{Q} 4$ & 2011Q1 & 2011Q2 & 2011Q3 & 2011Q4 \\
\hline Australia & 0.4 & 0.1 & 0.0 & -0.2 & 0.3 & 1.2 & 2.0 & 1.7 & 2.5 & 2.0 & 1.8 & 1.9 & 1.3 & 1.1 & 1.2 & 1.2 \\
\hline Austria & -0.2 & -0.4 & -0.6 & 0.2 & 0.1 & 0.0 & -0.1 & -0.3 & -0.3 & -0.1 & 0.0 & 0.1 & 0.1 & 0.0 & 0.1 & 0.0 \\
\hline Belgium & -0.1 & -0.3 & -0.4 & 0.4 & 0.4 & 0.5 & 0.6 & -0.3 & 0.0 & -0.1 & -0.2 & -0.1 & -0.3 & -0.4 & -0.3 & -0.5 \\
\hline Canada & -0.3 & 0.5 & 0.6 & 1.5 & 1.5 & 1.4 & 1.0 & 1.0 & 0.6 & 1.2 & 1.4 & 1.1 & 1.1 & 0.6 & 0.9 & 1.0 \\
\hline Czech Republic & -0.5 & 0.3 & 0.1 & -0.7 & -0.7 & -0.8 & -0.6 & 0.5 & 0.7 & 0.3 & 1.0 & 0.4 & 0.3 & 0.5 & -0.5 & -0.7 \\
\hline Denmark & 0.2 & 0.2 & -0.1 & 1.5 & 0.8 & 1.1 & 1.3 & 0.4 & 0.4 & 0.2 & 0.2 & 0.0 & 0.5 & 0.4 & 1.0 & 0.6 \\
\hline Finland & -0.1 & 0.1 & 0.0 & 0.0 & 0.5 & -0.2 & 0.6 & 0.6 & 0.3 & 1.0 & 0.6 & 0.5 & 0.2 & 0.0 & 0.1 & 0.1 \\
\hline France & -0.4 & -0.9 & -0.2 & 0.5 & 0.8 & 1.0 & 0.8 & 0.9 & 0.8 & 0.9 & 0.2 & -0.3 & -0.4 & -0.4 & -0.1 & 0.0 \\
\hline Germany & 0.3 & 0.2 & 0.9 & 0.4 & 0.8 & 1.2 & 0.4 & -0.1 & -0.2 & -0.7 & -0.2 & 1.5 & 0.9 & 1.3 & 1.4 & 0.7 \\
\hline Greece & 0.0 & -0.3 & 0.1 & -0.3 & -0.1 & 0.8 & 0.8 & 0.9 & 0.7 & -2.8 & -1.4 & -1.6 & -1.7 & -0.7 & -0.7 & -0.6 \\
\hline Ireland & 0.4 & 1.0 & 0.7 & 1.5 & 1.4 & 1.4 & 0.8 & 0.6 & 0.8 & -0.9 & -0.5 & -1.0 & -1.5 & -0.7 & -0.8 & -0.8 \\
\hline Italy & -0.1 & 0.0 & -0.3 & -0.2 & 0.1 & -0.1 & 0.2 & 0.2 & 0.2 & 0.1 & -0.1 & 0.2 & -0.1 & -0.2 & -1.1 & -1.6 \\
\hline Japan & 0.3 & 0.9 & 0.5 & -1.4 & -0.5 & -0.9 & -1.3 & -0.5 & -0.8 & -0.5 & 0.0 & 0.0 & 0.5 & 0.5 & 0.6 & 0.7 \\
\hline Korea & 1.3 & 1.4 & 0.1 & -0.8 & -0.8 & -1.0 & -0.2 & 0.3 & 0.6 & 1.0 & 0.9 & 0.8 & 0.6 & 0.6 & 0.4 & 0.3 \\
\hline Netherlands & 0.0 & 0.1 & 0.7 & 3.4 & 1.4 & 0.8 & 0.8 & -0.4 & -0.7 & -0.3 & -0.5 & -0.4 & -0.3 & -0.2 & -0.3 & -0.4 \\
\hline New Zealand & 0.4 & 0.5 & -0.2 & -0.1 & 0.0 & 0.3 & 0.7 & 0.4 & 0.6 & 0.4 & 0.8 & 1.5 & 1.6 & 1.9 & 1.6 & 0.7 \\
\hline Portugal & -0.2 & -0.3 & -0.1 & 0.2 & 0.3 & 0.7 & 0.0 & 0.2 & 0.1 & -1.8 & -0.6 & -1.2 & -1.3 & -1.0 & -1.3 & -1.2 \\
\hline Norway & 0.6 & 0.2 & -0.1 & 0.2 & -0.2 & -0.4 & 0.3 & 0.4 & 1.1 & 1.9 & 1.3 & 0.9 & 0.6 & -1.0 & -0.6 & -0.8 \\
\hline Slovenia & 0.3 & 0.2 & 0.3 & 0.2 & -0.1 & 0.7 & 1.3 & 1.0 & 1.8 & 0.9 & 0.3 & 0.3 & 0.9 & 0.4 & 0.4 & 0.2 \\
\hline Spain & -1.2 & -0.9 & 0.1 & 0.8 & 1.2 & 1.4 & 1.4 & 1.9 & 1.6 & 0.7 & 0.4 & -0.4 & -0.8 & -0.5 & -1.1 & -1.8 \\
\hline Sweden & -0.5 & -0.3 & -0.1 & 0.3 & 0.4 & 1.0 & 1.1 & 0.4 & 0.9 & 0.0 & -0.2 & 0.4 & -0.6 & 0.0 & 0.1 & 0.2 \\
\hline Switzerland & -0.5 & -0.7 & -0.6 & -1.1 & -0.9 & -0.9 & -1.1 & -0.3 & 0.1 & 0.0 & 0.1 & 0.0 & 0.2 & 0.3 & 0.7 & 0.3 \\
\hline United Kingdom & 0.2 & 0.0 & 1.4 & 0.7 & 1.6 & 0.8 & -0.2 & 0.1 & 0.8 & 1.0 & 0.9 & 1.6 & 0.4 & 0.2 & 0.5 & 0.0 \\
\hline United States & 0.2 & 0.2 & 0.8 & 1.2 & 1.2 & 1.3 & 1.1 & 0.6 & 0.5 & 0.5 & 0.9 & 0.8 & 0.9 & 0.6 & 0.4 & 0.3 \\
\hline
\end{tabular}

Note: The z-scores measure the relative size of net sales (red) or purchases (green) of government debt by foreign investors compared to historical norms. They are color coded as follows: red (less than -1); light red (between -1 and -0.5); light yellow (between -0.5 and 0.5 ); light green (between 0.5 and 1); and green (greater than 1 ).

Foreign investors started to differentiate more among countries during the euro area debt turmoil (2010-11). Between mid-2010 and end-2011, foreign investors cumulatively reduced their exposure to high-spread euro area sovereign debt by about US\$ 400 billion. This was part of the total foreign outflows these countries experienced during this time, resulting in large TARGET2 imbalances (Merler and Pisani-Ferry, 2012c). In contrast, noneuro area countries, in particular "other advanced economies", received large inflows during this period, as a percent of their total debt stock. Figure 7 shows the impact of these foreign portfolio shifts for the investor base of individual countries. It shows that the share of foreign investors in total debt stock declined for every single high-spread euro area country, while increasing for all "other advanced economies" (except Czech Republic) since end-2009.

Figure 7. Euro and Non-Euro Area: Foreign Holders of Government Debt, 2007-11 1/

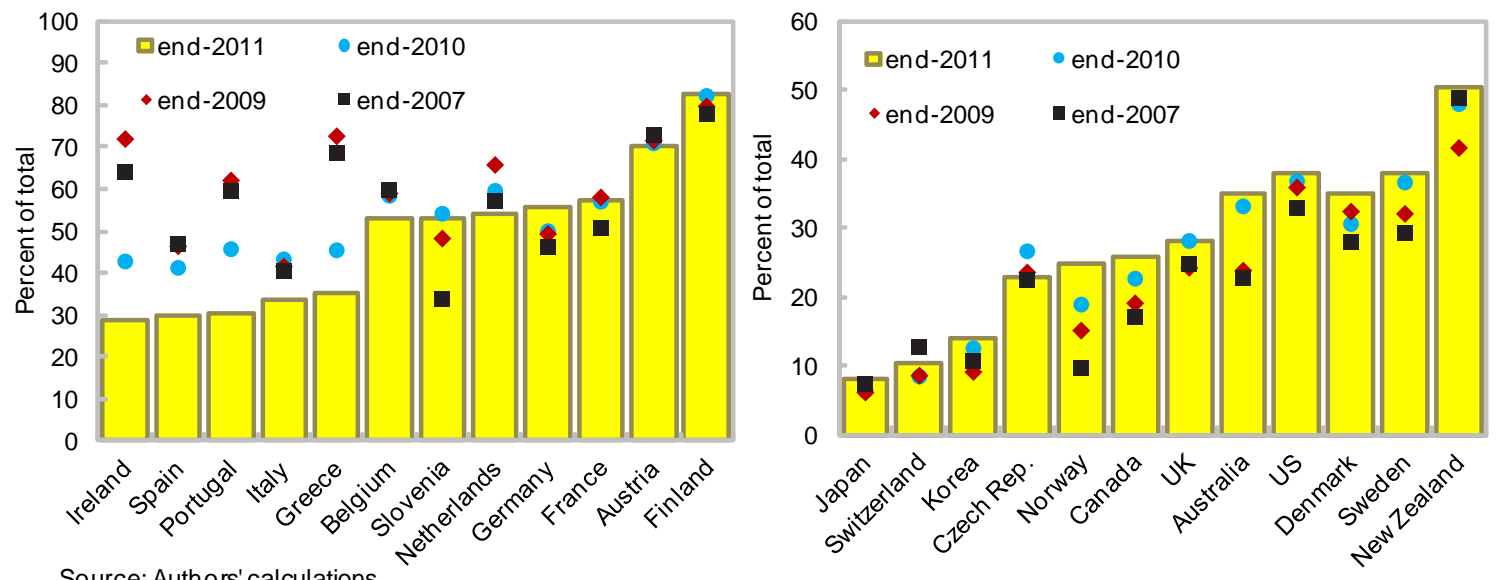

Source: Authors' calculations.

1/ Excluding fo reign official loans and SMP holdings of fo reign central banks. For Norway, excluding all external loans. 
Why did foreign investors show such country differentiation during 2010-11? A number of factors seem to have played a role. First, the emergence of credit risk (perceived and real) in a number of euro area countries likely altered the behavior of advanced economy sovereign investors that had previously focused primarily on interest rate risk. Second, largescale sovereign downgrades, especially for high-spread euro area countries, may have caused some institutional investors to divest from countries that no longer complied with their investment policies (Figure 8). Finally, the unusually high volatility of yields in some advanced economy sovereign bonds, compared to historical norms, likely caused some foreign investors to switch to countries with better perceived risk-return tradeoffs.

Figure 8. Advanced Economies: Sovereign Credit Ratings, 2004-11
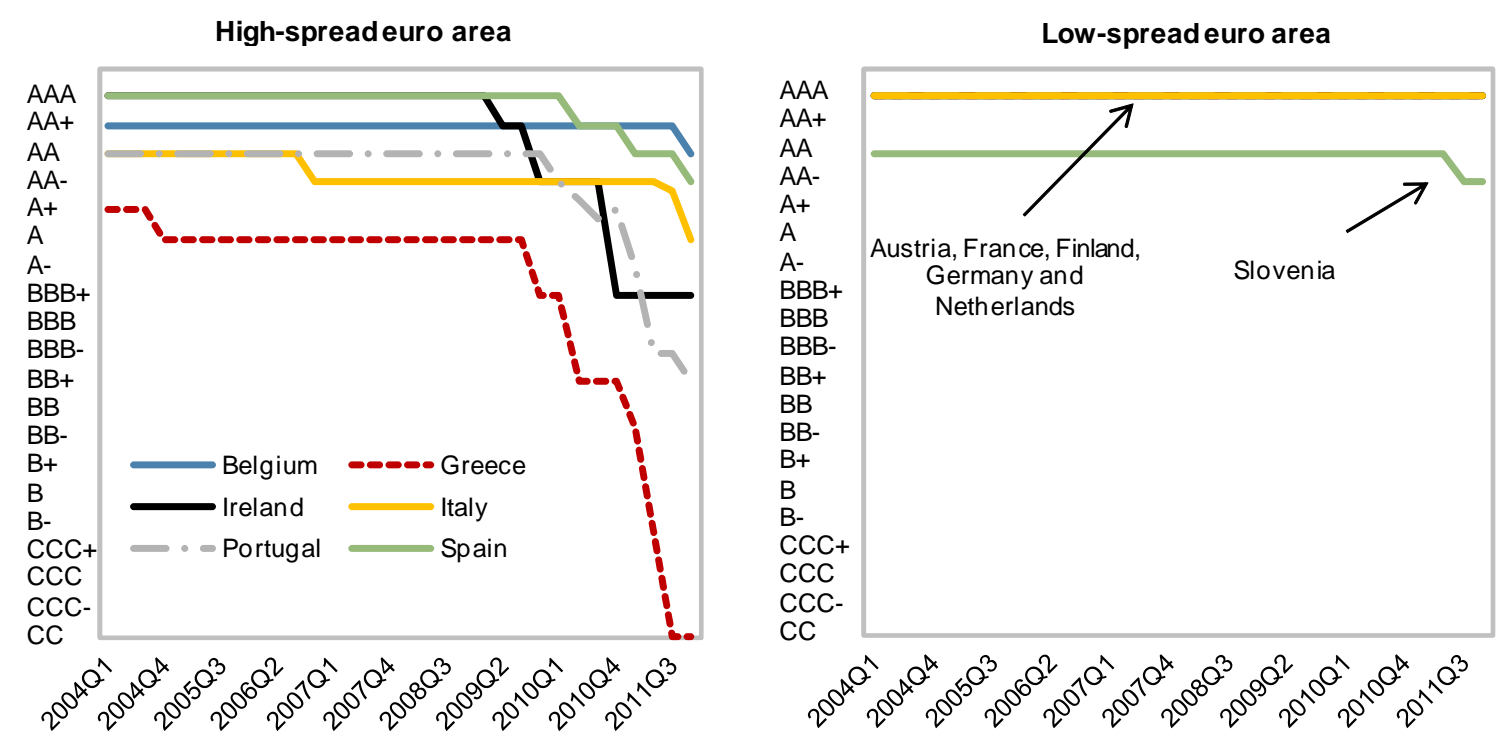

Traditional reserve countries
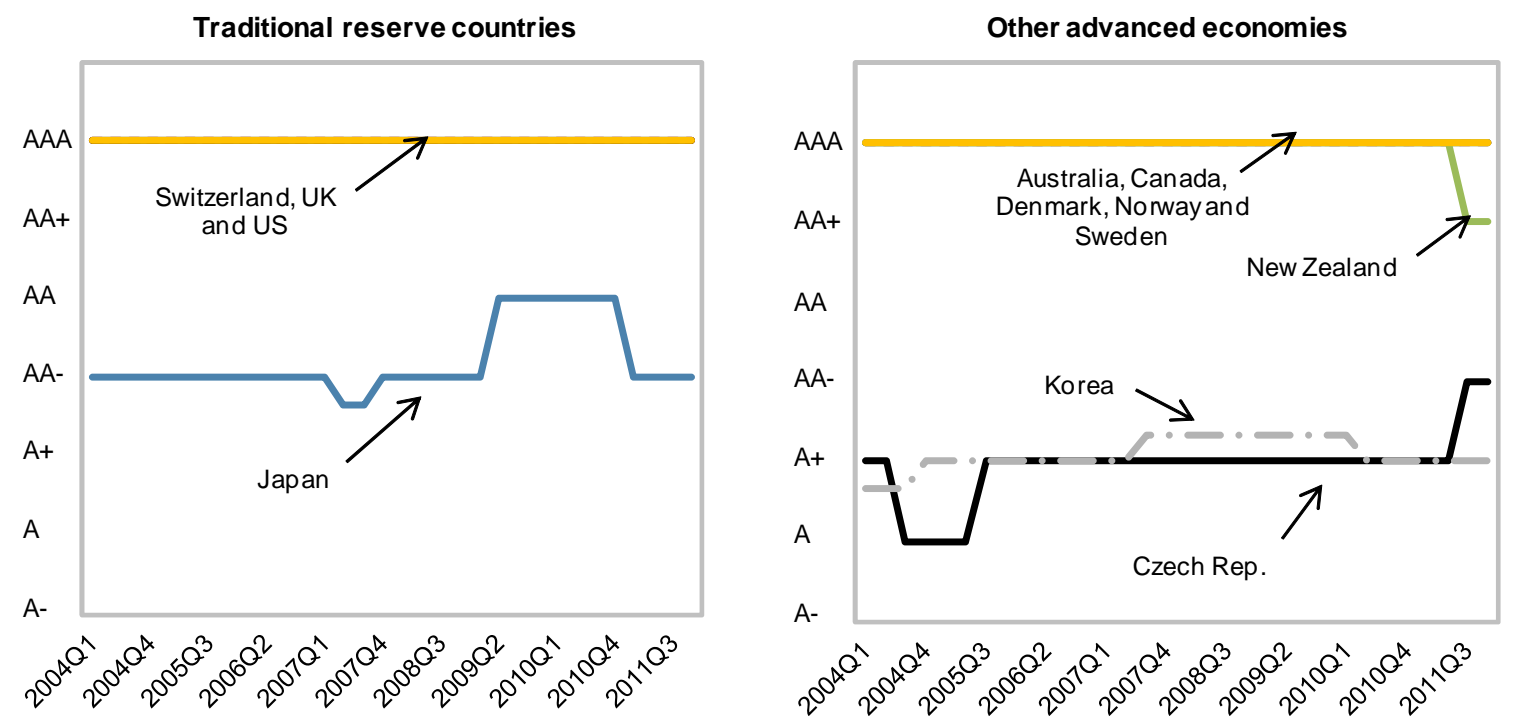

Sources: S\&P, Moody's, Fitch Ratings.

Note: Ratings at the end of each quarter. For each country, the rating was computed based on either the best two out-of-three ratings or simple average when all three agencies assigned different ratings. 
At the same time, international investors' exposure to the euro area as a whole still remains strong, but mainly due to Germany. Figure 9 shows cumulative sales and purchases of government debt by foreign investors during 2010-11. It shows that the reduction in exposure of foreign investors to high-spread euro area countries has been more than offset by their increased exposure to other euro area countries, in particular to Germany. This may partly explain why the euro has held up relatively well against major currencies despite the euro area debt turmoil.

Figure 9. Euro and Non-Euro Area Countries: Foreign Net Purchases of Government Debt, Cumulative over 2010-11
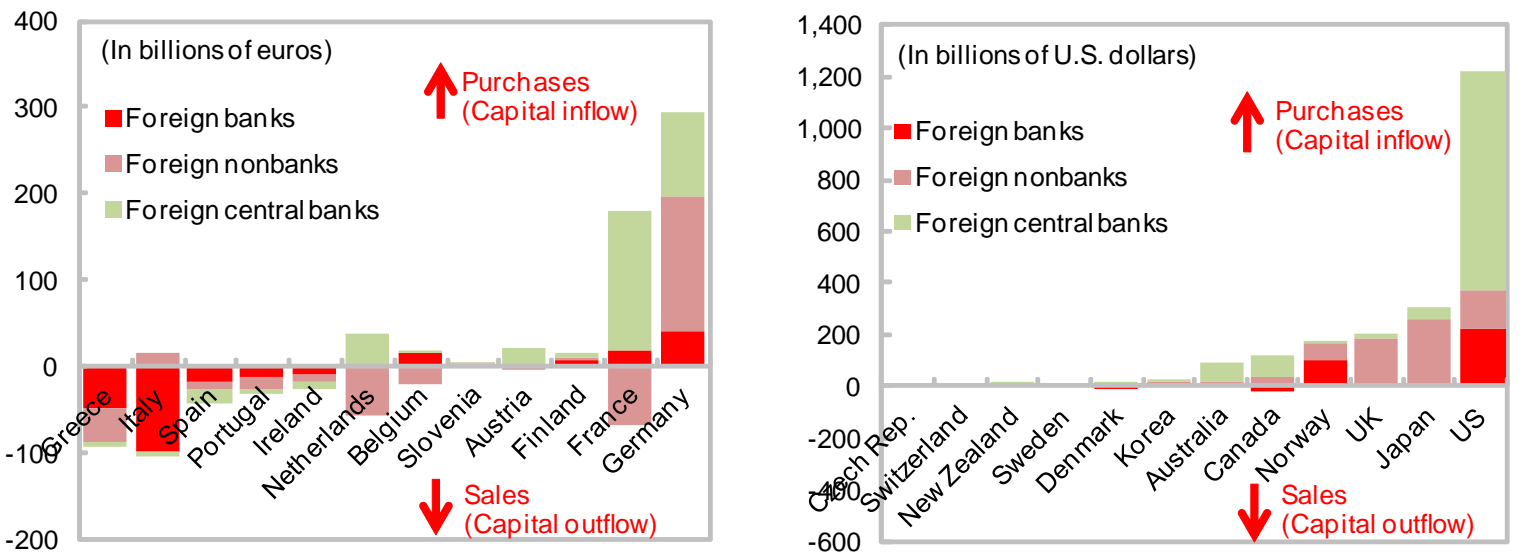

Source: Authors' calculations.

1/ Excluding foreign official loans and SMP holdings of foreign central banks. For Norway, excluding all external loans.

\section{B. How Did Foreign Demand Change by Investor Type?}

Our findings suggest that a large international portfolio reallocation took place among foreign investors, especially during the euro area debt turmoil, but their responses varied. Although their investment decisions had common elements, foreign investor responses varied in terms of scale, speed, and timing. Figures 10 and 11 show the estimated country allocations and investment flows of three types of foreign investors (foreign central banks, foreign banks, and foreign nonbanks), from which several observations can be drawn:

- $\quad$ Portfolio shifts of foreign central banks. Foreign central banks had negligible exposure to the high-spread euro area before the euro area debt turmoil (less than 7 percent). Hence, compared to other foreign investors, their investment outflows were much more limited (about US\$ 60 billion during 2010Q2-2011Q4), mainly reflecting outflows from Ireland and Spain (AAA countries before the debt turmoil).

Meanwhile, they have continued to increase their holding of low-spread euro area government debt (about US\$ 240 billion during the same period). In other words, they were net purchasers of euro area government debt during this period (unlike foreign banks and foreign nonbanks). At the same time, the share of euro area government debt has been declining in their total government debt portfolio, as they have significantly diversified their portfolios toward "other advanced economies." In particular, the share of "other advanced economies" in the advanced economy sovereign debt holdings of foreign central banks has risen from 2 to 6 percent since 
2007, according to our estimates. This is in line with the rise in foreign central bank demand for "alternative" reserve currencies documented elsewhere (Hyde, 2012).

- Portfolio shifts of foreign banks. Foreign banks began cutting exposure to highspread euro area countries starting from early 2010, much earlier than foreign nonbanks. Our estimates suggest that they started reducing their exposure to Greece in 2010Q1, followed by Portugal and Italy in 2010Q2, and then Ireland and Spain in 2010Q3. Overall, the reduction in their exposure to high-spread euro area countries was around US\$ 170 billion during 2010Q2-2011Q4. In contrast, they have increased exposure to low-spread euro area countries, especially to Germany, albeit in a smaller amount (around US\$ 50 billion). In fact, we find that they have been shifting their portfolio away from euro area government debt since 2008, while increasing exposure to government debt of traditional reserve countries (Japan, Switzerland, U.K., and U.S.). As a result, their government debt portfolios have become more concentrated. As of end-2011, we estimate that half of the sovereign exposure of foreign banks was to the United States and Germany alone.

- $\quad$ Portfolio shifts of foreign nonbanks. Foreign nonbanks have reduced exposure to high-spread euro area countries also in a significant way, pulling out a cumulative US\$ 160 billion during 2010Q2-2011Q4, most of which took place in late 2011. Their outflows, which happened only after the euro area debt turmoil intensified in 2011, represented an abrupt reversal of their long-term buying trend (Figure 11). While some of these outflows were offset by inflows into low-spread euro area countries (US\$ 110 billion), foreign nonbanks were net sellers of euro government debt during this period. In contrast, they were net buyers of the government debt of traditional reserve countries and, to a lesser extent, "other advanced economies." 19

Figure 10. Advanced Economies: Country Allocation of Foreign Investors, 2004-11 (In percent of total holdings of advanced economy sovereign debt)

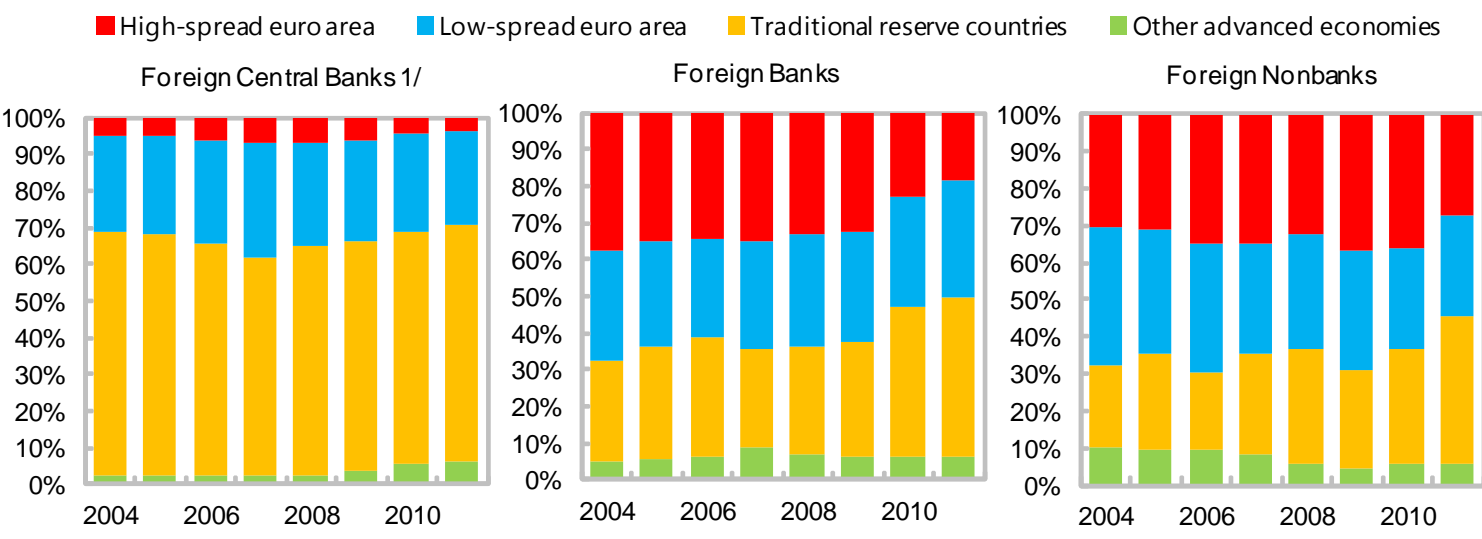

Source: Authors' calculations.

1/Excluding SMP holdings of fo reign central banks.

\footnotetext{
${ }^{19}$ A notable example of this trend is the Norwegian sovereign wealth fund, which recently announced a strategy to gradually reduce the fund's share of European bonds, while increasing bond investments in other regions.
} 
Figure 11. Advanced Economies: Cumulative Net Foreign Purchases of Government Debt, 2004-11

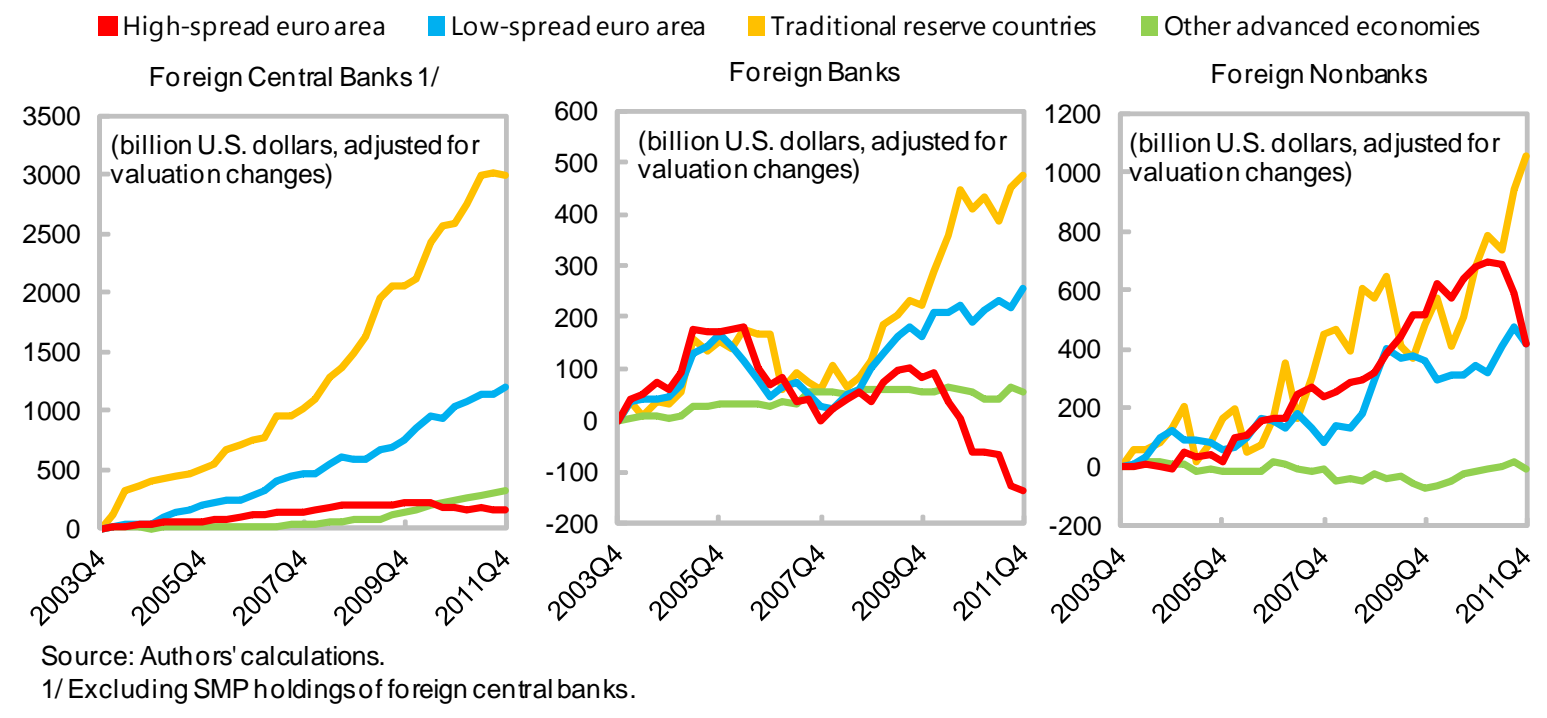

As a result, advanced economies experienced large inflows and outflows in government debt markets, especially in 2011 (Figure 12). Overall, the cumulative portfolio reallocation of foreign investors during 2011 suggests that foreign banks and nonbanks have reallocated their investment mainly within advanced economies. In contrast, foreign central banks have continued to increase their holdings mostly in a secular fashion. Countries that have received the largest demand from central banks include U.S., France, Germany, but also Canada, Australia, and Norway. The countries that received the largest demand from foreign banks include Japan, Germany, U.K., U.S., and France. Similarly, Japan, Germany, U.S., U.K., and Canada received the largest demand from foreign nonbanks.

Figure 12. Advanced Economies: Foreign Investors' Portfolio Reallocation in 2011
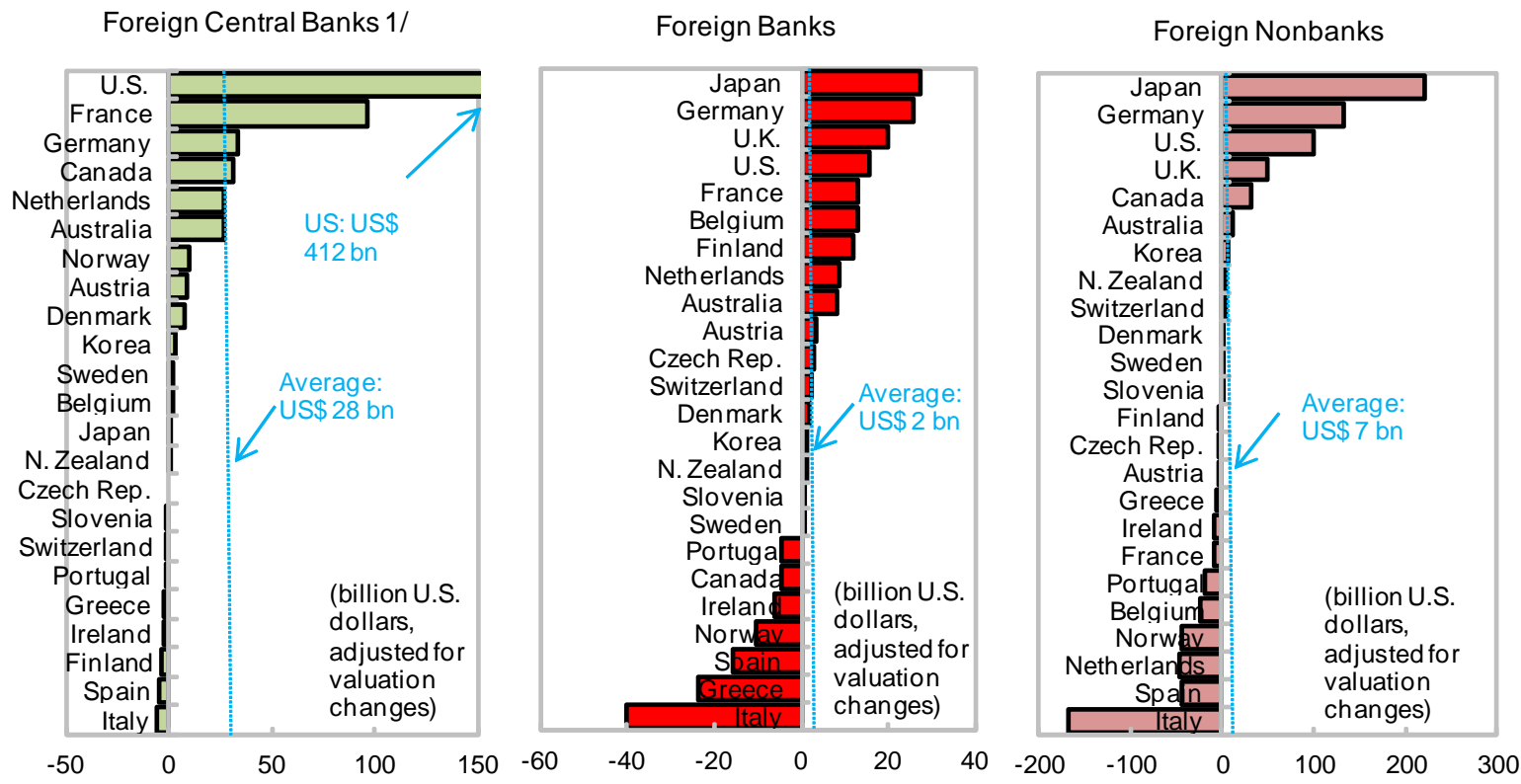

Source: Authors' calculations.

1/ Excluding SMP holdings of foreign central banks. 
The changes in foreign investors' positions seem to have been especially large during changes in sovereign credit ratings of high-spread euro area countries. Figure 13 shows our estimates of foreign investors' position (excluding official sector loans and SMP holdings of foreign central banks) for Ireland and Portugal before and after major sovereign downgrades. The foreign investor positions are calculated as the difference between each country's share in foreign holdings and each country's share in total debt outstanding (explained further in Section V.C). Based on this measure, foreign investor holdings were initially overweight Ireland and Portugal, but quickly became underweight as multi-notch sovereign downgrades for these countries took place. ${ }^{20}$ Although downgrades from AAA did not seem to have triggered large sales, foreign sales seem to have accelerated once credit ratings fell towards the lower end of AA rating.

Figure 13. Foreign Investors Position and Sovereign Downgrades, 2004-11

(Deviations from benchmark position in basis points)
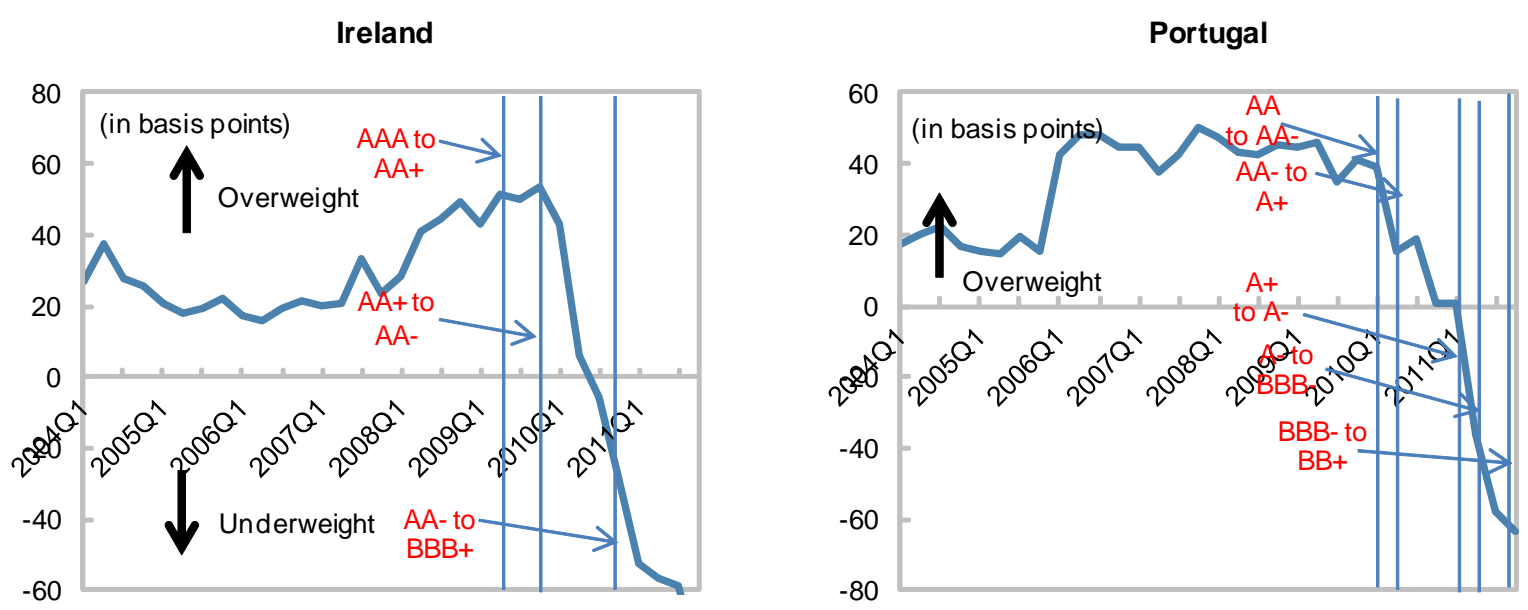

C. How Did Domestic Investors React to Falls in Foreign Demand?

Falls in foreign demand for sovereign debt and the resulting refinancing gaps were filled mostly by domestic banks, if not the foreign official sector or domestic nonbanks. In those countries where outflow of foreign investors have been most severe (Greece, Ireland, and Portugal), domestic banks have had to take up most of the slack that was not taken by the foreign official sector. In other highspread euro area countries, domestic nonbanks also contributed to additional demand for government debt, such as in Belgium, which had a successful retail

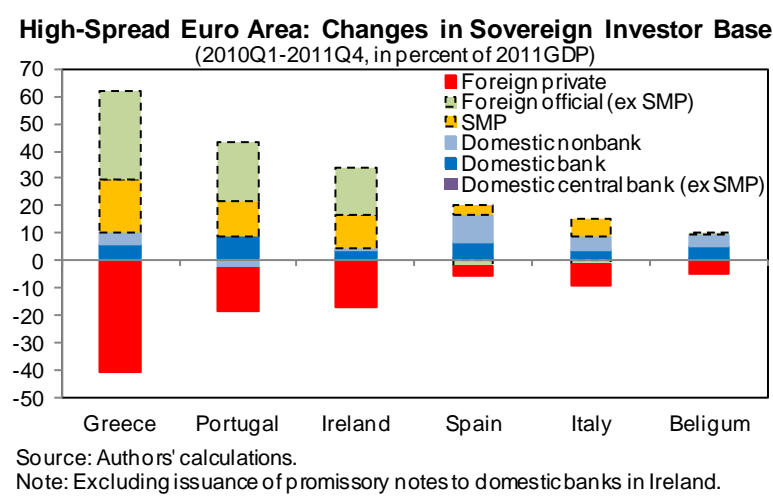

${ }^{20}$ IMF (2010) discusses some of the reasons why some investors may be more sensitive to rating actions, rather than market signals. 
bond issue to domestic households to alleviate funding pressures in November 2011. However, in general, funding gaps for countries that lost market access were filled by domestic banks. Based on these findings, Section V.A provides a framework for a sovereign funding shock analysis to assess the potential impact of foreign outflows on domestic banks.

\section{How Did Domestic Bank Demand Change More Generally?}

Domestic bank holdings of own government debt started increasing after the global financial crisis across most advanced economies, both in nominal terms and as a percent of banking sector assets. The increase is most evident in the euro area, where government debt held by domestic banks increased from 15 percent to about 20 percent of GDP (Figure 14). The increase can also be seen in terms of banking sector assets, indicating growing exposure of banks to their own government, which suggests stronger sovereign-bank linkages (Figures 15).

Figure 14. Advanced Economies: Bank Holdings of Own Government Debt, 2004-11
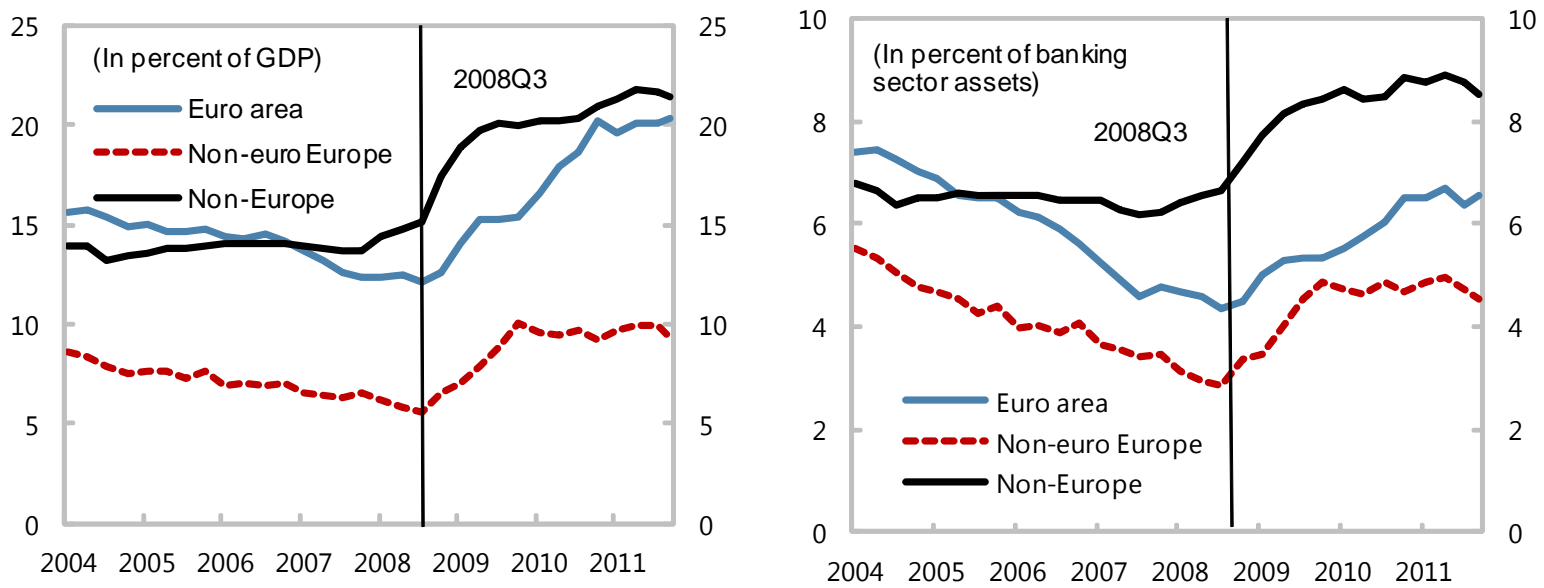

Sources: IMF International Financial Statistics, IMF Monetary and Financial Statistics, and authors' calculations.

Figure 15. Euro and Non-Euro Area: Bank Holdings of Own Government Debt, 2008-11
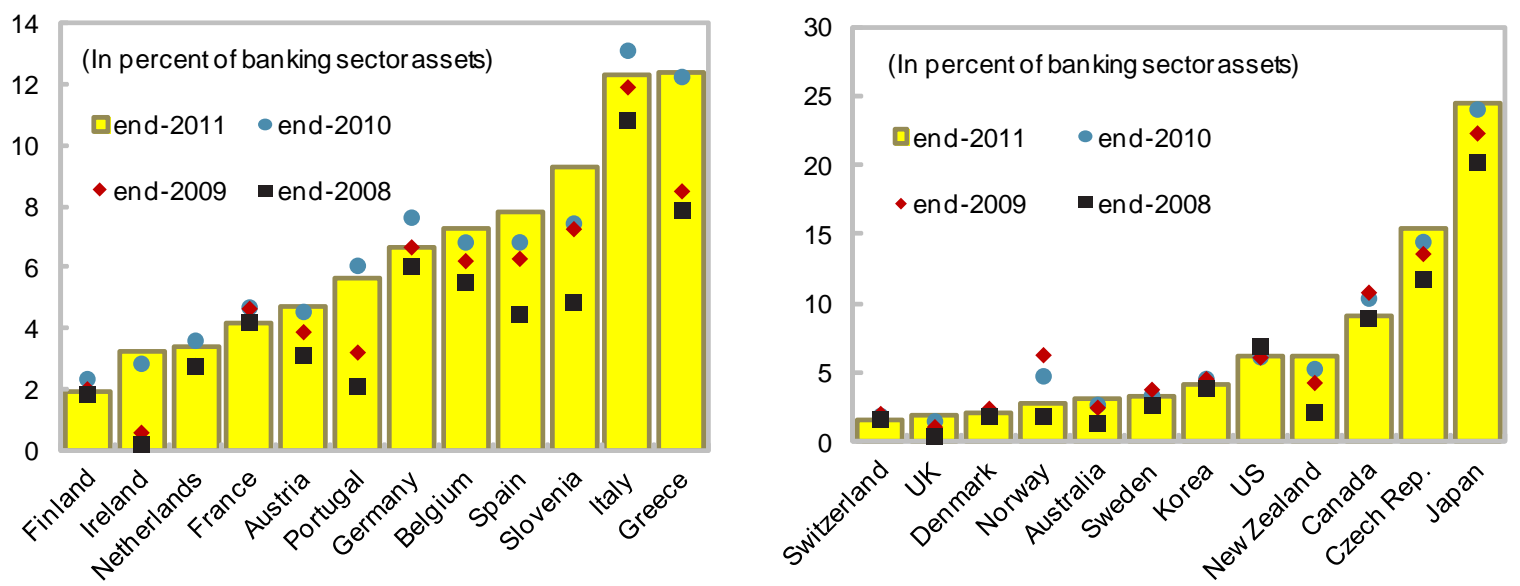

Sources: IMF International Financial Statistics, IMF Monetary and Financial Statistics, and authors' calculations. Note: The 2011 figure for Canada is as of end-2011Q3. 
Our findings also suggest a growing home bias in the euro area. The extent of home bias can be measured by the proportion of own sovereign debt held by banks within their overall sovereign debt holdings (Acharya et al, 2012). Based on this measure, home bias is large and growing in the euro area. Even before the crisis (at end-2007), euro area banks held, on average, 57 percent of their overall euro area government holdings in their own government debt, despite the fact that, for euro area banks, zero percent risk weights can be applied to the debt issued by any euro area sovereign. By end-2011, this ratio has increased to 69 percent. While the emergence of sovereign risk in parts of the euro area can explain some of the increase in home bias, it cannot fully explain it as the increase in own government holdings of euro area banks has been higher than the cumulative amount of foreign banks outflows from the high-spread euro area during this period. It also does not explain why home bias is a common trend across the euro area, including in the high-spread euro area. In some of these countries (Greece, Italy, and Spain), the ratio of own government debt to overall euro government debt holdings is now close to 100 percent.

Figure 16. Euro Area: Bank Holdings of Own Government Debt Securities, 2007-11

Euro Area: Bank Holdings of Own Government Securities, 2007-11 1/

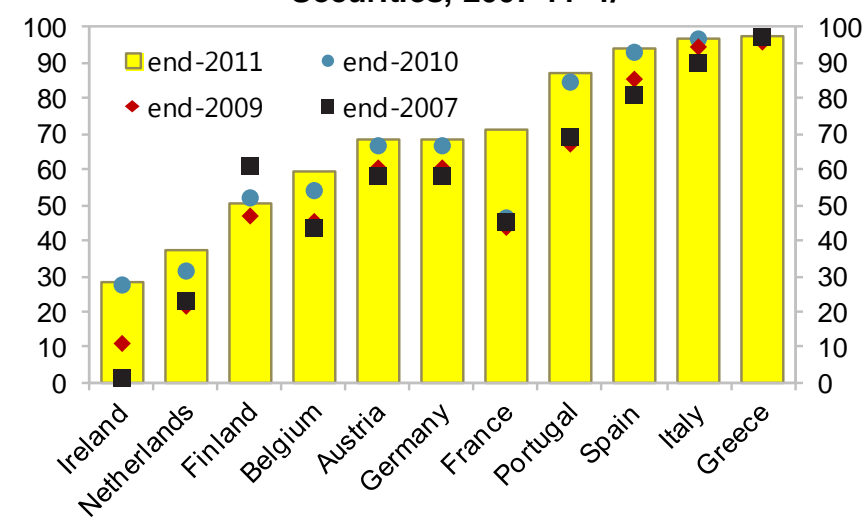

Sources: IMF International Financial Statistics, and authors' calculations. 1 / In percent of bank holdings of all euro area government securities.

The increased demand from domestic banks for their own government debt is a global phenomenon, suggesting that common factors are likely at play. Below we list some of these factors. While it is difficult to quantify the relative importance of each factor, they all seem to have played a significant role after the onset of the global financial crisis.

- The global recession. The reduced economic activity after the 2008 global financial crisis and the weak private sector growth in its aftermath - mostly in advanced economies - has reduced demand for bank loans and, as a result, banks have been accumulating government debt instead.

- Bank deleveraging. The deleveraging of advanced economy banks after the financial crisis has likely pushed banks to tilt their assets toward own government debt to reduce risk-weighted assets (RWA). The application of zero percent regulatory risk weights on debt issued by their own sovereigns creates such an incentive. 
- $\quad$ Basel III and new financial regulations. Banks are likely to have increased their demand for government debt in light of moves towards implementing Basel III and other regulatory changes that require tougher capital and liquidity standards and more use of collateral. ${ }^{21}$

- $\quad$ Rising home bias. As explained above, our findings suggest a growing home bias for domestic banks, in particular in the euro area. This cannot be explained only by the emergence of sovereign risk in other parts of the euro area.

- $\quad$ Other factors. An additional factor could be central bank operations in the post-crisis period. For instance, the ECB's long-term refinancing operations (LTROs) and changes in collateral criteria (e.g. no minimum rating thresholds for some euro area government debt) may have induced euro area banks to increase government debt holdings. At the same time, quantitative easing programs in Japan, U.K., and U.S. may have worked in the opposite direction, given their intended goal to reduce private holdings of government debt, including those held by domestic bank holdings.

Placing of bank recapitalization bonds in domestic banks (e.g. Ireland) or changes in national prudential norms may also have played a role.

The rise in bank holdings of own government debt risks stronger sovereign-bank linkages and negative feedback loops between the sovereign and its banks, potentially affecting domestic financial stability. On the one hand, strong demand from domestic banks helps public debt managers by providing a more stable investor base. On the other hand, too strong an interdependence between the sovereign and banks risks domestic financial stability, as discussed in Section II. ${ }^{22}$ For example, although Basel III liquidity reforms, which encourage banks to hold high-quality liquid assets such as sovereign debt, can help improve banks' liquidity conditions, they can also create stronger interdependence between the balance sheets of the sovereign and its banks. Alternatively, overexposure of banks to their own sovereign may hurt growth in the long-run, as banks move away from their traditional role of credit intermediation to the private sector ("crowding out").

\section{SOVEREIGN INVESTOR BASE RISK INDICATORS}

In this section, we develop three risk indicators related to a sovereign's investor base. These aim to capture the vulnerability of a country's investor base to a sudden outflow by different types of investor.

\footnotetext{
${ }^{21}$ The 2011 EBA stress tests suggested that major European banks may have a collective shortfall of $€ 1.2$ trillion that must be filled with liquid assets such as government bonds. Santos and Elliott (2012) estimate that European, Japanese, and U.S. banks may collectively need US\$ 2 trillion of net additional liquid assets in the next three years before the Liquidity Coverage Ratio (LCR) becomes effective in 2015. At the same time, another Basel III liquidity measure, Net Stable Funding Ratio (NSFR), scheduled take effect in 2018, may induce some banks to reduce demand for long-term government debt.

${ }^{22}$ Merler and Pisani-Ferry (2012b) argue that the interdependence between banks and sovereigns is especially strong in the euro area, due to the absence of a supranational banking resolution framework and domestic banks holding a considerable share of the debt issued by their domestic government.
} 
- $\quad$ Sovereign funding shock scenarios. We provide a framework to simulate forwardlooking sovereign funding shock scenarios to assess the vulnerability of a country to sudden foreign outflows, based on its ability to rely on its domestic institutional investors and banking sector as alternative investors. In doing so, this framework also explores the domestic financial stability implication of a withdrawal of foreign investors from sovereign debt markets, as discussed in Section II.

- Investor base risk index. We construct an index that aims to assess which countries are more prone to sudden investor outflows. This index highlights differences in the stability of the various investor types, as identified from our dataset.

- $\quad$ Foreign investor position index. We construct an index to track the country positions of foreign investors, as compared to a benchmark portfolio. This can give a sense of how foreign investors are shifting their advanced economy sovereign debt portfolios.

\section{A. Sovereign Funding Shock Scenarios}

\section{The Sovereign Funding Shock Scenarios (FSS) aim to assess a country's ability to manage a hypothetical loss of market access through greater reliance on domestic} investors. It envisages a funding shock that is triggered when foreign private investors pull out of a country's sovereign debt market over a one year horizon, either due to a change in country fundamentals or other external factors. ${ }^{23}$ We then examine whether domestic investors can step in to fill the gap. In particular, we assume that domestic institutional investors (insurance companies, pension funds, investment funds) are able to reallocate one percent of their assets under management to domestic sovereign debt, while the rest of the gap is filled entirely by domestic banks. ${ }^{24}$ This is in line with our findings in Section IV.C that during episodes of large foreign withdrawals, domestic banks have absorbed most of the funding gap. Furthermore, we assume the domestic central bank does not engage in directly buying government debt during the stress episode, either because it does not have such a mandate or because it prefers to act as a buyer of last resort after all options are exhausted. This is broadly in line with the facts observed during the euro area debt turmoil. The three euro area countries under the EU/IMF program are excluded from the scenarios, as foreign official sectors are already playing a significant role in filling the gap left by foreign private investors. While the aim of the exercise is to identify which countries may be more vulnerable to foreign outflows, such vulnerability may also make those countries more likely to experience a self-fulfilling debt crisis, in the absence of support from official creditors. Finally, this exercise focuses on withdrawal of foreign investors and its implication for government's refinancing risk. Hence, it does not take into account other potential

\footnotetext{
${ }^{23}$ Foreign private investors include foreign banks and foreign nonbanks. We exclude foreign official sector holdings because, to a large extent, these take the opposite direction as foreign private holdings during a crisis.

${ }^{24}$ In some countries, such as Belgium, domestic retail investors have also increased their holdings of sovereign debt when there were large foreign outflows. However, the pattern of retail investors varies across countries and hence, for this analysis, we assume holdings of these investors remain broadly unchanged, unless through their indirect holdings of sovereign debt via financial intermediaries.
} 
adjustment processes, such as the depreciation of the exchange rate that may help stem the outflows. Box 2 provides more details on the methodology used in this analysis.

This exercise envisages three shock scenarios. In all scenarios, the projected overall fiscal deficit, and hence the projected supply of debt over the next year, remains the same. ${ }^{25}$ In contrast, foreign investors change their investment policies in each scenario, thereby affecting the demand for debt. In particular, we consider the following three scenarios with increasing severity: ${ }^{26}$

Scenario 1 (100 percent rollover). Foreign private investors stop financing their share of the government deficit but roll over all debt holdings coming due over the next year.

- $\quad$ Scenario 2 (0 percent rollover). Foreign private investors stop financing their share of the government deficit and do not roll over the debt maturing over the next year.

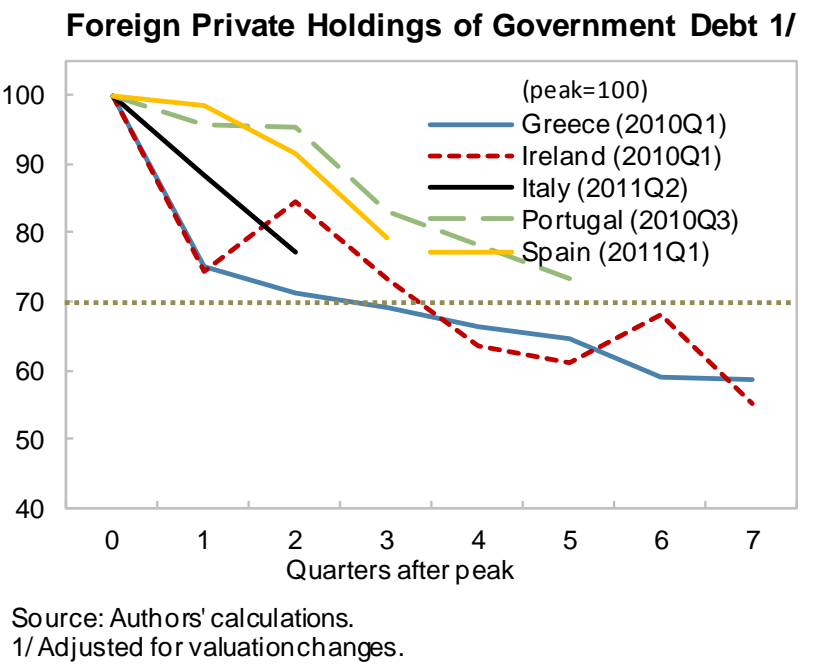

- $\quad$ Scenario 3 (0 percent rollover plus 30 percent sale). Foreign private investors stop financing their share of the government deficit; do not roll over the debt maturing over the next year; and sell a portion (30 percent) of their remaining exposure. 30 percent is based on the recent experience of distressed euro area countries (Greece, Ireland, and Portugal), where foreign private investors reduced their holdings by 30 percent, on average, over a one year period after their peak level.

\section{Box 2: Methodology of Sovereign Funding Shock Scenarios}

The sovereign funding shock scenarios (FSS) rely on three parameters regarding investment decisions of foreign private investors, namely: (i) their contribution to funding of the overall fiscal deficit over the next year $(\alpha)$; (ii) their rollover of short-term government debt by residual maturity (i.e. debt maturing over the next year) ( $\beta$ ); and (iii) their sale of long-term government debt holding by residual maturity $(\gamma)$. $\alpha$ determines the extent to which foreign private investors contribute to the net financing needs of the government, while together, $\alpha$ and $\beta$ determine the extent to which they contribute to the gross financing needs of the government. Finally, $\gamma$ determines how much debt is liquidated beyond gross financing needs.

Fiscal funding needs and rollover needs are calculated based on data from IMF WEO database and BIS Securities Statistics, respectively. In particular, we use the projected general government deficit from the

\footnotetext{
${ }^{25}$ This is a conservative assumption, as interest payments and the resulting overall fiscal deficit may increase if borrowing costs rise under the shock scenarios, amplifying worries about debt sustainability.

${ }^{26}$ In all scenarios, the foreign share of the fiscal funding needs and rollover needs is based on the foreign share of the total debt stock as of end-2011.
} 
WEO and the stock of short-term government securities (on a remaining maturity basis) from BIS Securities Statistics to estimate these variables. The following formulas illustrate these concepts in more detail:

First, we can decompose the gross financing needs of the government as follows:

$$
G F N_{t}=D_{t}+M_{t}=F D_{t}+O D_{t}+F M_{t}+O M_{t}
$$

Where: GFN, D, and M stand for gross financing needs, fiscal deficit, and maturing debt, respectively. FD and OD stand for fiscal deficit financed by foreign private and other investors, respectively, while FM and OM stand for maturing debt held by foreign private and other investors, respectively.

Then, we assume private foreign private investors' respective share of contribution to financing fiscal deficit and short-term debt is proportional to their share in the total debt stock:

$$
\begin{array}{cc}
F D_{t}=D_{t} * F S_{t} / T S_{t} & O D_{t}=D_{t} * O S_{t} / T S_{t} \\
F M_{t}=M_{t} * F S_{t} / T S_{t} & O M_{t}=M_{t} * O S_{t} / T S_{t}
\end{array}
$$

Where: FS, TS, and OS stand for debt stock held by foreign private investors, total debt stock, and debt stock held by other investors, respectively.

We assume further that foreign private investors contribute to $\alpha$ percent of the annual fiscal funding needs, roll over $\beta$ percent of their share of the maturing debt, and sell $\gamma$ percent of their remaining stock.

Hence, foreign outflows can be computed as follows:

$$
\text { Foreign Outflows }=(1-\beta) F M_{t}+\gamma\left(F S_{t}-F M_{t}\right)
$$

In turn, the additional government debt stock taken up by domestic banks due to the shock can be obtained as follows:

$$
\text { Additional Debt }=D_{t}(1-\alpha)+\text { Foreign Outflows }- \text { Debt take up by domestic non banks }
$$

Debt taken up by domestic nonbanks is assumed to be one percent of the financial assets of domestic institutional investors. The size of the assets under management of domestic institutional investors can be obtained from the OECD Institutional Investors Database.

Finally, the resulting domestic bank holding of own government debt is obtained as follows:

$$
\text { Bank Holding of Own Government Debt }=D B S_{t}+\text { Additional Debt }
$$

Where: DBS stands for domestic bank holding at time $t$.

With respect to the specific scenarios considered in this paper, the parameters are set as follows: Scenario 1 assumes $\alpha$ is equal to $0, \beta$ is equal to 100 percent, and $\gamma$ is equal to 0 ; Scenario 2 assumes $\alpha, \beta$, and $\gamma$ are all equal to 0; and Scenario 3 assumes $\alpha$ and $\beta$ are equal to 0 , and $\gamma$ is equal to 30 percent.

\section{Results are assessed through the impact of foreign outflows on the balance sheet of domestic banks. In particular, we first examine the additional amount of sovereign debt}


domestic banks would need to take up under these scenarios as a percent of their assets. A higher ratio suggests banks may have difficulty in absorbing the shock, potentially leading to increases in government bond yields. Then, we examine the resulting level of sovereign debt that would be held by domestic banks. A higher ratio suggests growing interdependence between banks and the sovereign, which could jeopardize domestic financial stability. It may also suggest that banks may be becoming constrained in providing credit to the private sector with potentially harmful consequences for long-term economic growth ("crowding out").

\section{Results show that large funding gaps may arise in a number of advanced economies under the shock scenarios, requiring large absorption by domestic banks (Figure} 17). Overall, countries with a higher share of foreign private investors in the investor base, a smaller size of banking sector assets, and a shorter maturity of the government debt portfolio, tend to be more sensitive to the shock. The countries that appear most vulnerable to the shocks in terms of the additional amount of debt that would need to be absorbed are Belgium, Czech Republic, Italy, and Slovenia, where the sovereign exposure of domestic banks would need to increase by more than 5 percentage points of assets under the severest shock (0 percent rollover plus 30 percent sale). On the other hand, Australia, Denmark, Sweden, and Switzerland appear highly resilient to the shocks, due to their lower share of foreign private investors and larger banking sectors. With respect to the resulting level of sovereign debt, Italy and Slovenia appear more vulnerable to the shock scenarios, as their domestic banking system would end up with a high level of exposure to their own sovereign, with more than 15 percent of bank assets dedicated to own sovereign debt under the severest shock. The countries that already have a high level of bank exposure to their own sovereign debt also appear vulnerable in that regard (Japan and Czech Republic). 
Figure 17. Advanced Economies: Sovereign Funding Shock Scenarios 1/

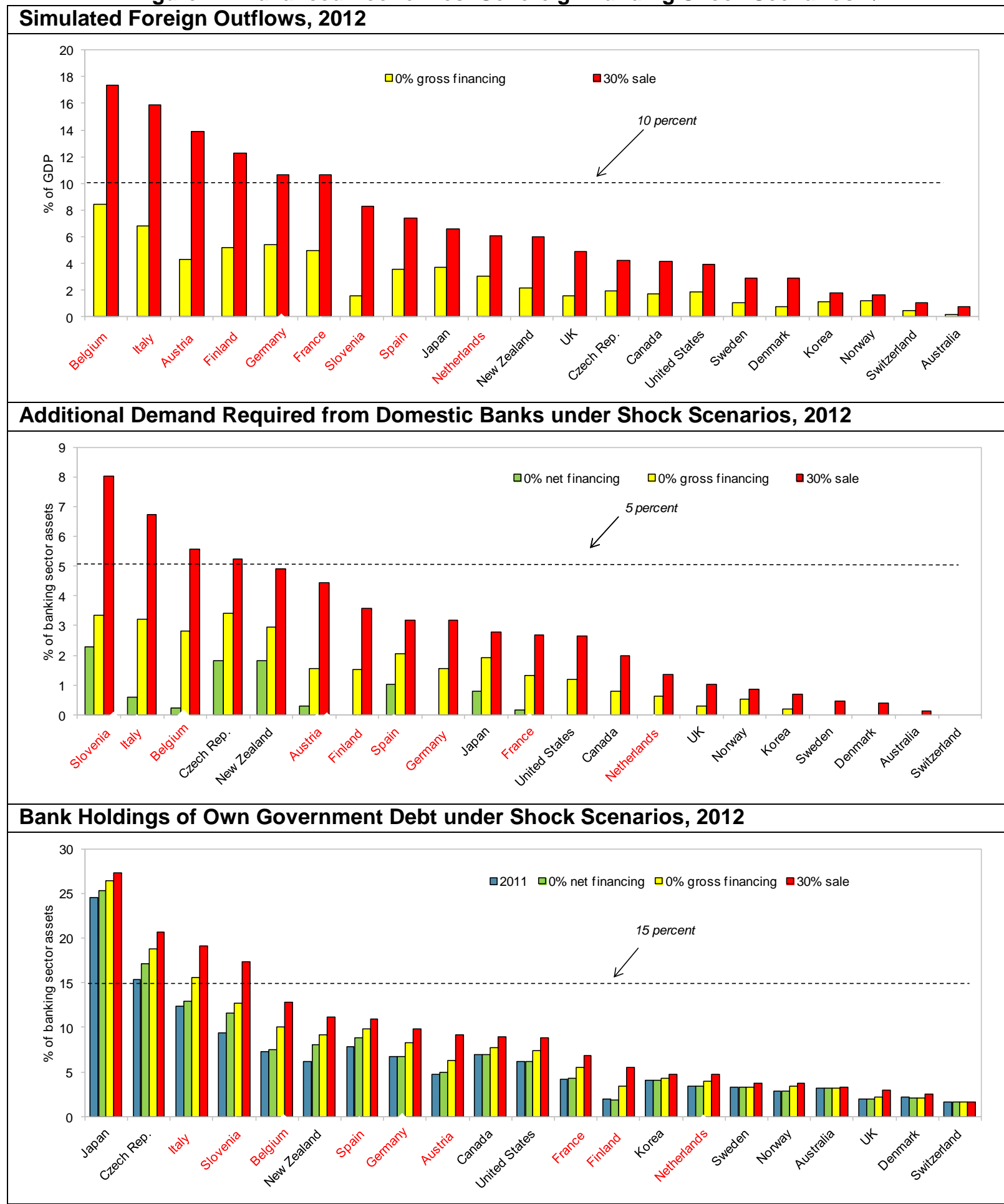

Sources: IMF/World Bank QEDS; IMF IFS, OECD and WEO databases; and authors' estimates.

$1 /$ Based on assumptions on the rollover and sale decisions of foreign private investors regarding their sovereign debt holdings. "0\% net financing" indicates that foreign private investors stop financing their share of the government deficit but roll over their existing debt stock. " $0 \%$ gross financing" indicates that foreign private investors stop financing their share of the government deficit and do not roll over the debt maturing over the next year. "30\% sale" indicates that foreign private investors do not provide any new financing and sell a portion (30 percent) of their remaining exposure. Euro area countries are identified in red. 


\section{Limitations}

- $\quad$ These results may underestimate the shock that may need to be absorbed by domestic banks in the event that foreign investors also withdrawal from non-sovereign debt markets (e.g. domestic bank securities or corporate debt securities markets). To the extent that these shocks are positively correlated, the full impact may be even larger.

- $\quad$ Our calculations assume that the foreign private investors' share of the short-term debt is proportional to their share in total debt. In cases where foreign investors hold a disproportionately larger share of short-term debt (e.g. Japan), potential foreign outflows may be larger than estimated. Alternatively, if foreign investors hold a disproportionally smaller share of short-term debt (e.g. Slovenia), foreign outflows may be lower than estimated. ${ }^{27}$

- Different maturity structures and rollover needs of foreign banks and nonbanks are not addressed in this exercise, while in reality banks tend to hold shorter duration debt than nonbanks. The maturity information provided by the latest European Banking Authority (EBA) stress tests can partly address this issue, providing indicative values on the maturity of sovereign bond holdings of large banks. By doing so, differences in the duration of debt holding of banks and nonbanks can be taken into account. At the same time, EBA data itself suffers from limited coverage (only large banks in European countries) and low frequency of updates.

\section{B. Investor Base Risk Index}

The Investor Base Risk Index (IRI) aims to reflect the likelihood of sudden outflows by different types of investor in the sovereign investor base. The index can take a value from 0 to 100 with a higher score implying that the country is more prone to a sudden investor outflow. The index can be seen as complementary to the FSS. While the FSS aims to assess the vulnerability of a country in a hypothetical sudden investor outflow scenario, the IRI aims to capture the likelihood of such an event materializing. The index is constructed in three steps:

- $\quad$ Historical correlations. First, we calculate the historical correlation between log changes in investor holdings and log changes in sovereign bond yields, as an approximation of the "price sensitivity" of different investors. The data on investor holdings come from our own dataset. For sovereign bond yields, we use the generic 10 -year sovereign bond yields provided by Bloomberg. The correlations, which are estimated over the post-crisis period, suggest that different investors tend to change their holdings differently when sovereign yields change (Table 6). In particular, domestic investors and foreign central banks tend to increase their holdings during

\footnotetext{
${ }^{27}$ The share of foreign investors in the short-term and long-term debt markets can be calculated based on data available from BIS, Eurostat, QEDS, and national authorities. Taking these into account, we have re-run the analysis. The results were broadly the same for most countries.
} 
periods when sovereign yields rise, while foreign private investors tend to reduce them. ${ }^{28}$ Although these correlations do not imply causation, they suggest that, on average, domestic investors and foreign central banks can play a stabilizing role when bond yields rise (as they tend to increase their holdings during these periods), while foreign banks and nonbanks can play a destabilizing role (as they tend to reduce their holdings instead).

- $\quad$ Risk scores for each investor. Second, we assign a risk score from 0 to 100 to each investor, based on the correlations calculated in the previous step. We do so by applying a simple linear transformation on the estimated correlation coefficients so that the highest positive correlation maps to a risk score of 0 and the highest negative correlation maps to 100. Accordingly, domestic central banks get a risk score of 0 and foreign nonbanks get a risk score of 100 (Table 6). From these scores, some useful insights can be brought about. First, the score for foreign central banks suggests that they may have the similar risk characteristics, on average, as domestic nonbanks. Second, based on these risk scores, domestic bank holdings would reduce investor base risk but not as much as domestic nonbanks. Third, foreign nonbanks can be viewed as a particularly risky investor class, even more than foreign banks. One reason why foreign nonbanks may be more risky than foreign banks is that they may be more prone to herd behavior given that their investments mandates may require them to follow certain portfolio benchmarks or, in some cases, sovereign ratings. Similarly, the investment decisions of foreign nonbanks may carry longer term implications, as, once they change their investment mandates, they may not easily reverse their investment flows (Vause and von Peter, 2011).

Table 6. Risk Scores by Investor Type

\begin{tabular}{lcc}
\hline & Correlation 1/ & Risk Score 2/ \\
\hline Domestic central bank & 0.148 & 0 \\
Domestic bank & 0.056 & 26 \\
Domestic nonbank & 0.093 & 16 \\
Foreign central bank 3/ & 0.097 & 14 \\
Foreign bank & -0.162 & 87 \\
Foreign nonbank & -0.207 & 100 \\
\hline
\end{tabular}

Source: Authors' calculations.

1/ For each investor, the correlation indicates the average correlation betw een log changes in investor holdings and log changes in the 10-year sovereign bond yields for all countries in the sample during the post-crisis period (2008Q3-2011Q4).

$2 /$ The risk scores are obtained by applying a linear transformation on correlation coefficients, such that the highest coefficient has a score of 0 and the low est one 100.

3/ Excluding SMP holdings of foreign central banks.

- Investor base risk index (IRI). Finally, we assign an aggregate risk score to the overall investor base of each country by calculating the weighted average of the risk score for each investor, where the weights are based on the share of the corresponding

\footnotetext{
${ }^{28}$ This is an average across all countries in the sample during the post-crisis period. We have also calculated median correlations and the results were similar, suggesting results were not driven by outliers.
} 
investor in the total debt stock. Accordingly, a country whose debt is fully held by its domestic central bank would have an IRI of 0 , while another country whose debt is fully owned by foreign nonbanks would have an IRI of 100 .

\section{The IRI suggests that euro area countries that received EU/IMF support in 20010-11 exhibited high investor base risk even before they lost market access (Figure 18). All} euro area countries show a high risk score, reflecting in the high level of financial integration in the region and the resulting high share of foreign private investors in their investor base. In particular, Greece, Portugal, and Ireland can be identified as countries with an especially risky investor base as early as 2010. The risk scores for Spain and Italy, on the other hand, is only moderately high, given the high share of domestic banks and nonbanks in their investor base. Their risk score also declines after SMP purchases of their government debt began in 2011Q3. Austria and Finland are surprising cases, as they have a high risk index; however, as we discuss further below, they have lower levels of debt. In contrast, Australia, Japan, Switzerland, and the U.S. are identified as countries with a particularly safe investor base.

Figure 18. Advanced Economies: Investor Base Risk Index, 2008-11

\begin{tabular}{|c|c|c|c|c|c|c|c|c|c|c|c|c|c|c|c|c|}
\hline & $\begin{array}{c}2008 \\
\text { Q1 }\end{array}$ & $\begin{array}{c}2008 \\
\text { Q2 } \\
\end{array}$ & $\begin{array}{c}2008 \\
\text { Q3 }\end{array}$ & $\begin{array}{c}2008 \\
\text { Q4 }\end{array}$ & $\begin{array}{c}2009 \\
\text { Q1 }\end{array}$ & $\begin{array}{c}2009 \\
\text { Q2 }\end{array}$ & $\begin{array}{c}2009 \\
\text { Q3 } \\
\end{array}$ & $\begin{array}{c}2009 \\
\text { Q4 }\end{array}$ & $\begin{array}{c}2010 \\
\text { Q1 }\end{array}$ & $\begin{array}{c}2010 \\
\text { Q2 } \\
\end{array}$ & $\begin{array}{c}2010 \\
\text { Q3 } \\
\end{array}$ & $\begin{array}{c}2010 \\
\text { Q4 } \\
\end{array}$ & $\begin{array}{c}2011 \\
\text { Q1 } \\
\end{array}$ & $\begin{array}{c}2011 \\
\text { Q2 }\end{array}$ & $\begin{array}{c}2011 \\
\text { Q3 } \\
\end{array}$ & $\begin{array}{c}2011 \\
\text { Q4 } \\
\end{array}$ \\
\hline \multicolumn{17}{|l|}{ Euro Area } \\
\hline Austria & 67 & 67 & 65 & 64 & 64 & 64 & 64 & 65 & 63 & 62 & 61 & 61 & 60 & 60 & 60 & 58 \\
\hline Belgium & 55 & 54 & 54 & 57 & 57 & 56 & 56 & 54 & 55 & 53 & 54 & 53 & 53 & 52 & 52 & 49 \\
\hline Finland & 53 & 56 & 56 & 60 & 64 & 59 & 63 & 64 & 63 & 62 & 62 & 60 & 60 & 61 & 62 & 63 \\
\hline France & 47 & 47 & 48 & 49 & 49 & 48 & 47 & 46 & 46 & 46 & 44 & 42 & 41 & 42 & 41 & 39 \\
\hline Germany & 32 & 31 & 32 & 33 & 36 & 36 & 37 & 36 & 35 & 34 & 36 & 37 & 36 & 38 & 40 & 40 \\
\hline Greece & 71 & 70 & 72 & 70 & 69 & 71 & 74 & 75 & 73 & & & & & & & \\
\hline Ireland & 23 & 29 & 34 & 38 & 42 & 47 & 51 & 54 & 55 & 49 & 51 & & & & & \\
\hline Italy & 48 & 49 & 48 & 47 & 48 & 48 & 49 & 48 & 49 & 50 & 50 & 50 & 50 & 50 & 48 & 44 \\
\hline Netherlands & 44 & 43 & 43 & 50 & 52 & 48 & 49 & 47 & 45 & 42 & 42 & 40 & 37 & 36 & 34 & 32 \\
\hline Portugal & 60 & 60 & 61 & 62 & 62 & 63 & 61 & 62 & 62 & 60 & 62 & 60 & 59 & & & \\
\hline Slovenia & 53 & 52 & 52 & 50 & 50 & 54 & 57 & 57 & 64 & 63 & 62 & 61 & 67 & 68 & 66 & 60 \\
\hline Spain & 44 & 44 & 44 & 44 & 44 & 44 & 46 & 47 & 48 & 46 & 47 & 46 & 44 & 44 & 42 & 39 \\
\hline
\end{tabular}

Non-Euro Area

Australia

Canada

Czech Republic

Denmark

Japan

Korea

New Zealand

Norway

Sweden

Switzerland

United Kingdom

United States

\begin{tabular}{|l|l|l|l|l|l|l|l|l|l|l|l|l|l|l|l|}
\hline 19 & 19 & 19 & 19 & 19 & 19 & 18 & 19 & 19 & 18 & 19 & 19 & 18 & 19 & 20 & 21 \\
\hline 29 & 29 & 29 & 29 & 30 & 31 & 28 & 29 & 28 & 29 & 29 & 28 & 28 & 28 & 29 & 29 \\
\hline 39 & 42 & 41 & 38 & 36 & 37 & 37 & 40 & 40 & 40 & 42 & 43 & 42 & 43 & 42 & 39 \\
\hline 34 & 34 & 32 & 36 & 35 & 36 & 32 & 29 & 28 & 28 & 30 & 30 & 33 & 32 & 34 & 30 \\
\hline 22 & 22 & 23 & 22 & 22 & 22 & 22 & 22 & 21 & 21 & 22 & 22 & 22 & 22 & 23 & 23 \\
\hline 25 & 25 & 23 & 22 & 21 & 20 & 21 & 22 & 22 & 23 & 24 & 24 & 24 & 25 & 25 & 25 \\
\hline 52 & 53 & 51 & 52 & 51 & 52 & 51 & 48 & 49 & 49 & 52 & 53 & 55 & 56 & 56 & 55 \\
\hline 31 & 30 & 29 & 26 & 27 & 27 & 28 & 31 & 31 & 33 & 34 & 33 & 33 & 30 & 30 & 25 \\
\hline 31 & 30 & 28 & 29 & 29 & 34 & 34 & 30 & 33 & 29 & 31 & 31 & 28 & 28 & 30 & 32 \\
\hline 24 & 24 & 24 & 22 & 21 & 21 & 21 & 22 & 22 & 22 & 22 & 21 & 22 & 23 & 24 & 23 \\
\hline 19 & 20 & 21 & 21 & 23 & 21 & 19 & 19 & 19 & 22 & 22 & 24 & 23 & 23 & 25 & 25 \\
\hline 24 & 23 & 24 & 25 & 25 & 22 & 22 & 23 & 24 & 22 & 23 & 23 & 23 & 22 & 22 & 22 \\
\hline
\end{tabular}

Source: Authors' calculations.

Note: Figures in each cell indicate the investor base risk index constructed by authors. Cells are color coded by quintiles. In particular, green represents the bottom quintile, blue the second quintile, yellow the third quintile, orange the forth quintile, and red the top quintile. The quintiles are based on all observations during 2004Q1-2011Q4. 
A simpler version of the IRI would be to simply calculate the foreign private share. This approach would essentially be a more discrete version of the IRI, where domestic investors and foreign central bank are scored as 0 and foreign banks and nonbanks are scored as 100 . Indeed, as sensitivity analysis, the investor base risk index was also calculated using just the aggregate foreign private share. The results were broadly the same.

The IRI, which is essentially a demand-side risk indicator, is especially useful when used in combination with a supply-side risk indicator of sovereign debt. In particular, the IRI could be combined with current or projected debt-to-GDP ratios, or other indicators of supply of government debt, to provide a more comprehensive measure of sovereign risk. By doing so, sovereigns that are vulnerable to refinancing risk both from supply and demand perspectives can be identified. Figure 19 provides a stylized framework for this approach. The two-by-two table shows countries can be classified into one of four quadrants depending on (i) whether their supply of debt is high or low; and (ii) whether their investor base risk is high or low. The best case scenario is represented by Quadrant III (i.e. low debt and low investor base risk), while the worst case is represented by Quadrant II (i.e. high debt and high investor base risk).

Figure 19. A Stylized Framework for Sovereign Risk Analysis

\begin{tabular}{|c|c|c|c|}
\hline & \multicolumn{2}{|c|}{ Demand-side Risk Indicator } \\
\hline & & Low & High \\
\hline \multirow{2}{*}{ 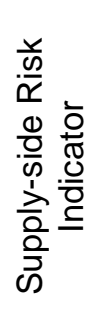 } & High & $\begin{array}{c}\text { Quadrant I } \\
\text { High Debt but } \\
\text { Resilient to a Run }\end{array}$ & $\begin{array}{l}\text { Quadrant II } \\
\text { High Debt and } \\
\text { Prone to a Run }\end{array}$ \\
\hline & Low & $\begin{array}{c}\text { Quadrant III } \\
\text { Low Debt and } \\
\text { Resilient to A Run }\end{array}$ & $\begin{array}{l}\text { Quadrant IV } \\
\text { Low Debt but } \\
\text { Prone to a Run }\end{array}$ \\
\hline \multicolumn{4}{|c|}{$\begin{array}{l}\text { Source: Authors. } \\
\text { Note: Supply-side risk indicators could include gross debt-to-GDP } \\
\text { ratio, net debt-to-GDP ratio, projected debt-to-GDP ratio or other } \\
\text { measures of the supply of government debt. Demand-side risk } \\
\text { indicators could include the investor base risk index constructed by } \\
\text { the authors or any other measure that captures the refinancing risks } \\
\text { inherent in the sovereign investor base. }\end{array}$} \\
\hline
\end{tabular}

An application of this framework reveals interesting results. Figure 20 shows a possible application of our stylized framework as of end-2009 (i.e. before the euro area debt problems began). ${ }^{29}$ By combining our index with the projected debt-to-GDP ratio in the October 2009 WEO, we allocate countries into the four quadrants, as described above. Quadrant I (high debt/ low investor base risk) includes Germany, Japan, U.K., and U.S. Quadrant II (high $\mathrm{debt/high} \mathrm{investor} \mathrm{base} \mathrm{risk)} \mathrm{includes} \mathrm{all} \mathrm{the} \mathrm{high-spread} \mathrm{euro} \mathrm{area} \mathrm{countries} \mathrm{(as} \mathrm{they} \mathrm{later}$ became) as well as Austria and France. Quadrant III (low debt/low investor base risk)

\footnotetext{
${ }^{29}$ Our index is based on historical correlations during the post-crisis period, including 2010 and 2011 . In that sense, this should not be seen as an out-of-sample test of our index. We provide it only for illustrative purposes.
} 
includes Switzerland and "other advanced economies" with the exception of New Zealand. Quadrant IV (low debt/ high investor base risk) includes Finland, Netherlands, New Zealand, and Slovenia. Although hindsight is perfect, this classification is remarkably close to how markets ended up differentiating these countries in terms of sovereign risk when sovereign debt problems emerged after 2009.

Figure 20. Advanced Economies: Application of Investor Base Risk Index, end-2009

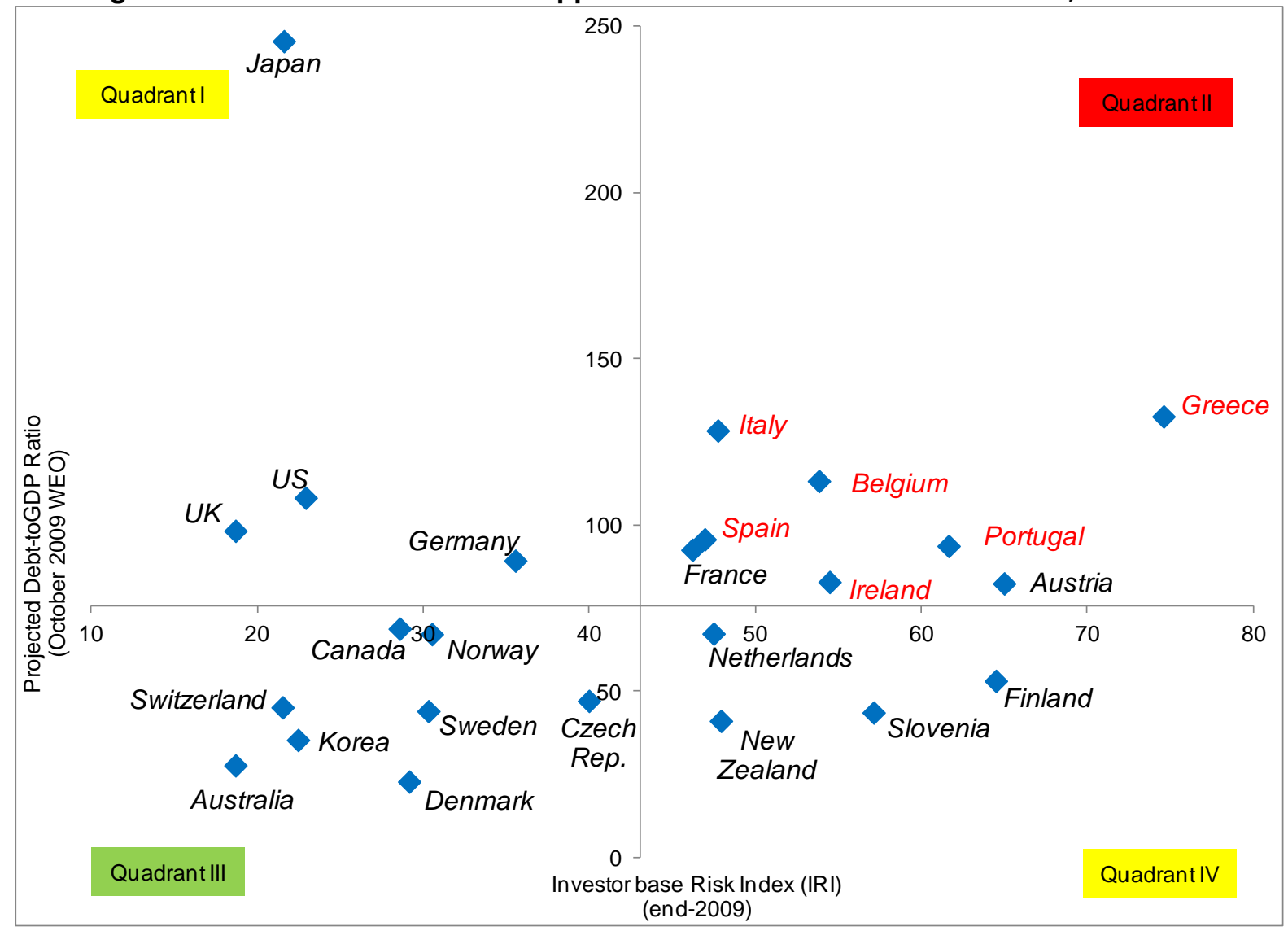

Note: Projected debt-to-GDP ratios are five year forward projections of general government gross debt in the October 2009 WEO. Investor base Risk Index is constructed by the authors. The cross point shows the median of both indicators. High-spread euro area countries are shown in red.

The IRI can also explain some of the classic "puzzles" as to why some countries are able to sustain much higher levels of debt without market pressure. For example, despite continued worries about Japan's fiscal outlook, demand for Japanese government bonds (JGBs) has been increasing as reflected in falling JGB yields. That is partly because the JGB market offers a level of liquidity that no other domestic asset class can match, which essentially creates a stable domestic investor base that is less prone to sudden outflows-a fact that is also captured by our risk index. In such cases, high debt-to-GDP levels may matter less, as the likelihood of a run by sovereign investors is also less. This may give countries much more room to tackle their fiscal problem, compared with others that may face market pressure right away, even at lower levels of government debt. In that respect, the IRI suggests that Germany, U.K, and, U.S. may be in the same category as Japan (Figures 19 and 20), although for a different reason: Those countries rank low in the IRI because of the high share of foreign and domestic central banks in their investor base (Annex Figure 1). 


\section{Limitations}

- $\quad$ The IRI relies on historical correlations, during a particular period (2008Q32011Q4). It is possible that these correlations may change over time.

- $\quad$ The IRI is calculated based on simple correlation coefficients between investor holdings and sovereign bond yields. This could lend itself to more formal empirical analysis between these two variables to better pin down the risk characteristics of different investors.

- While the IRI does not consider the domestic financial stability implications of the investor base, a very low risk index may mean too much reliance on domestic investors (in particular domestic banks), and should also be seen as a worrying sign. A more diversified investor base, represented by more foreign holders, may be more desirable in such cases, even though it would increase the risk index.

\section{Foreign Investor Position Index}

The Foreign Investor Position Index (FIPI) aims to estimate the position of foreign investors with respect to the outstanding debt portfolio of each country. The goal is to explore how foreign investors may be positioned compared to other investors, which may have a bearing on country's sovereign bond market or exacerbate market volatility if there is sudden change in investor sentiment. For purpose of this exercise, we focus on foreign investor holdings excluding foreign official loans and SMP holdings of foreign central banks.

The analysis uses different benchmark portfolios for euro area and non-euro area countries, reflecting differences in regional financial integration. For each group, the benchmark portfolio is constructed as the total debt outstanding of all countries within the group, where the weights represent the each country's share in the total debt stock. We then compare each country's share in foreign investor holdings with their share in the benchmark portfolio. By doing so, we can obtain a rough estimate of whether the country is underweight or overweight in the portfolio of foreign investors. The following formulas illustrate this concept for each group:

$$
\begin{gathered}
\operatorname{FIPI}_{i}=\frac{F_{i}}{\sum_{i}^{N} F_{i}}-\frac{D_{i}}{\sum_{i}^{N} D_{i}} \\
\text { FIPI }_{i}<0: \text { Underweight } \\
\text { FIPI }_{i}>0: \text { Overweight }
\end{gathered}
$$

Where:

$F_{i}$ : Foreign investor holding of country i's sovereign debt, excluding foreign official loans and SMP holdings of foreign central banks.

$D_{i}$ : Outstanding sovereign debt of country $i$, where i refers to all countries in the euro or non-euro group. 
The FIPI suggests that foreign investors exhibit significant deviation from benchmark portfolios for a number of countries (Figure 21). In the euro area, foreign holdings are significantly overweight with respect to Germany and France, while significantly underweight Italy and Spain. In the non-euro area, foreign holdings appear overweight with respect to the U.K. and Australia, while underweight Korea and Switzerland. There are also two outliers: Foreign holdings are significantly overweight the U.S., potentially owing to the U.S. dollar's key role as an international currency, and significantly underweight Japan, reflecting Japan's highly concentrated domestic investor base. With respect to "other advanced economies," foreign holdings appear overweight with respect to all of them except for Korea, possibly reflecting growing demand of foreign investors for alternative currency exposures (see section IV.B).

Figure 21. Advanced Economies: Foreign Investor Position Index (FIPI), end-2011

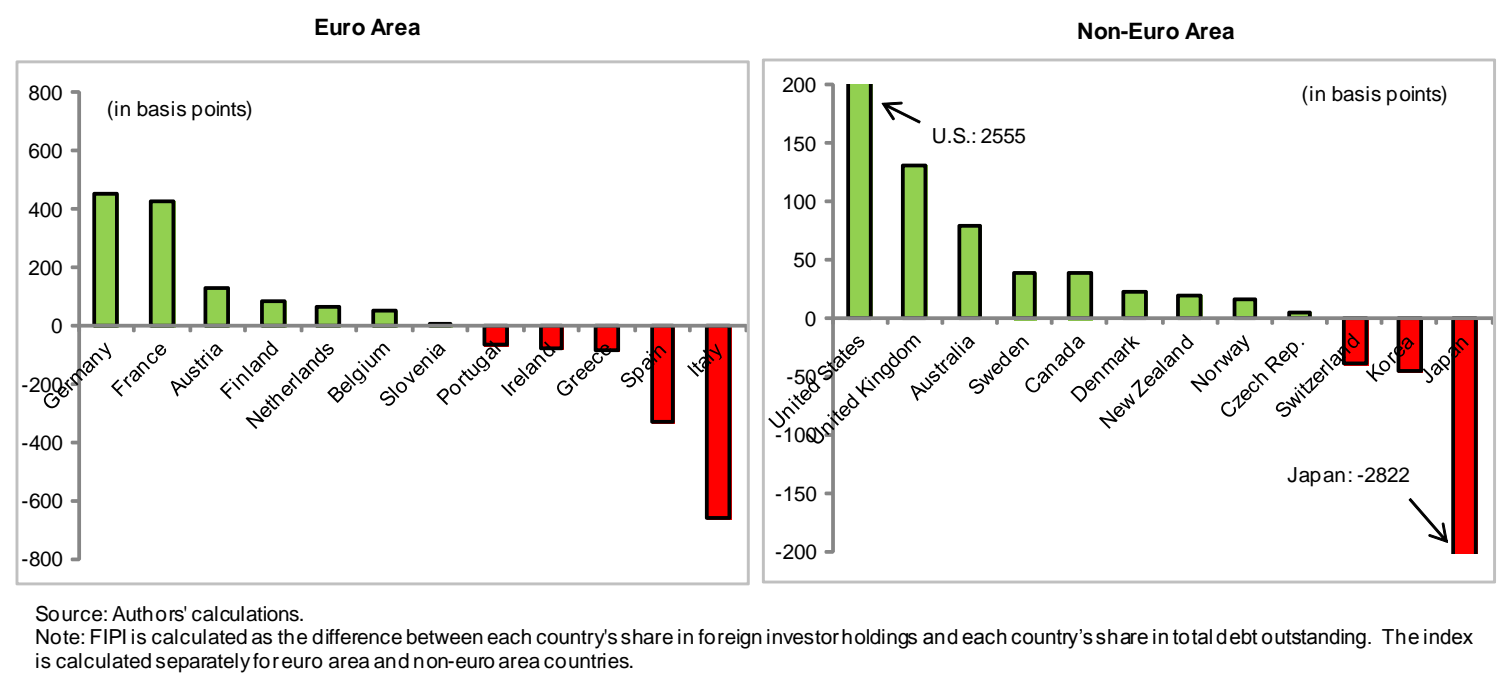

\section{Limitations}

- The index may vary depending on the choice of the benchmark. As an extension, different indices that include only a subset of sample countries, for instance by credit ratings, can be used to analyze foreign holdings from different angles.

- $\quad$ The index does not differentiate between loans and securities exposures. As an extension, the index could be constructed only for marketable securities. 


\section{Conclusion}

We introduce a methodology for compiling internationally comparable estimates of sovereign debt holdings. Based on this methodology, we construct a comprehensive dataset for advanced economies. The methodology can be used to track US\$ 42 trillion of advanced economy sovereign debt held by six different investor classes - domestic central banks, domestic banks, domestic nonbanks, foreign official sector, foreign banks, and foreign nonbanks. The dataset, which covers 24 countries during the period from 2004 to 2011 on a quarterly basis, is publicly available along with this paper.

Based on our analysis of the dataset, we identify a number of common trends across investors of advanced economy sovereign debt, with several policy implications. In general, for most advanced economies, we find a rising share of foreign investors in sovereign debt markets and a rising exposure of banks to own government debt after the global financial crisis. The main policy implications are as follows:

- $\quad$ Public debt mangers should continue to pay attention to investor relations and monitor government refinancing risk closely through scenario analysis. With large sovereign debt repayments looming over the next few years, the ability to retain market access will depend critically on the predictability and stability of the investor base. Coupled with the fact that most advanced economies are increasingly reliant on foreign investors, this means that debt managers need to have a rigorous investor relations program and market surveillance operations. In formulating debt management strategies, closer attention should be placed on investors' asset allocation strategies. Further, debt managers need to remain flexible in their issuance strategies. In this context, the principles brought out in the "Stockholm Principles" for public debt management provide a good operating framework. ${ }^{30}$

- $\quad$ Financial sector supervisors should place more emphasis on macro-financial risks emanating from bank holdings of sovereign debt. In the short run, higher domestic bank ownership of sovereign debt may help provide a more stable investor base for the government. However, in the longer-run, any deterioration in the sovereign's credit quality can increasingly trickle into the health of the domestic banking system. In turn, contingent liability risks from banks to the sovereign may increase. In order to reduce these negative feedback loops, strengthening backstop mechanisms to support banking systems, along with higher loss-absorbing capital at banks may be needed. Financial stability authorities may also need to consider conducting regular systemic stress tests with credible sovereign risk scenarios. The results of these tests could be announced to the public to help reduce undue market concerns. Such stress test exercise could also be coordinated with public debt managers to better capture refinancing risks in government debt markets.

\footnotetext{
${ }^{30}$ The "Stockholm Principles" are a set of guiding principles for managing sovereign risk and high levels of public debt, as facilitated by the IMF and agreed by the debt managers and central banks who attended the $10^{\text {th }}$ Annual Consultations on Policy and Operational Issues facing Public Debt Management on July 1-2, 2010.
} 
- Standard debt sustainability analyses (DSA) should be complemented with investor base risk indicators to better capture sovereign risk. The euro area debt turmoil highlighted the importance of investor base dynamics. These market and investor factors are increasingly becoming an important source of sovereign risk (Das, Oliva, and Tsuda, 2012). Against this background, we have constructed a number of risk indicators that policy makers can use, along with conventional debt sustainability indicators, to capture vulnerabilities to sudden investor outflows.

- $\quad$ Further efforts to reduce data gaps on investor holdings of sovereign debt could be of significant benefit to policy makers. Our dataset is a first attempt at this goal, but this agenda could be developed further. For example, more granular information on holders of sovereign debt can provide further information on how spillovers from one sovereign bond market could be transmitted to another. More granular data on different foreign investors, often treated as a single unit in national statistics, can also be useful, given the importance of these investors and differences in their investment strategies. Ongoing initiatives that can help reduce data gaps include the 2009 G20 Data Gaps Initiative, which includes a recommendation to improve data collection on securities holdings (Recommendation 7). In response, a joint BIS-ECB-IMF initiative has released a handbook in 2010 to improve data collection on debt securities holdings (Handbook on Securities Statistics, Part 2). For the euro area, there is an ongoing initiative of the ECB to collect further information on holdings of securities through the Centralized Securities Database.

There are a number of areas that were not tackled in this paper and would benefit from further research. The methodology and the dataset provided in this paper could form the beginning of a wider research agenda on sovereign debt and sovereign debt holdings. Issues that have not been tackled in this paper include: (i) empirically examining the relationship between the level and volatility of sovereign bond yields and different investor holdings (the latter can be an important omitted variable in regressions that attempt to explain sovereign bond yields); (ii) examining how the diversity of the investor base affects the liquidity of sovereign debt markets; (iii) analyzing how investor base should be factored when crisisrelated monetary and financial policies are eventually unwound; and (iv) assessing how the impact of new financial regulations may be affecting sovereign debt markets through their impact of investor holdings. 


\section{Annex Figure 1. Advanced Economies: Holders of Government Debt, 2004-11}

(components in percent; total in percent of GDP)

Foreign official

Domesticnonbank

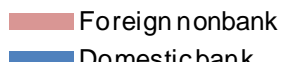

Domesticbank

Australia

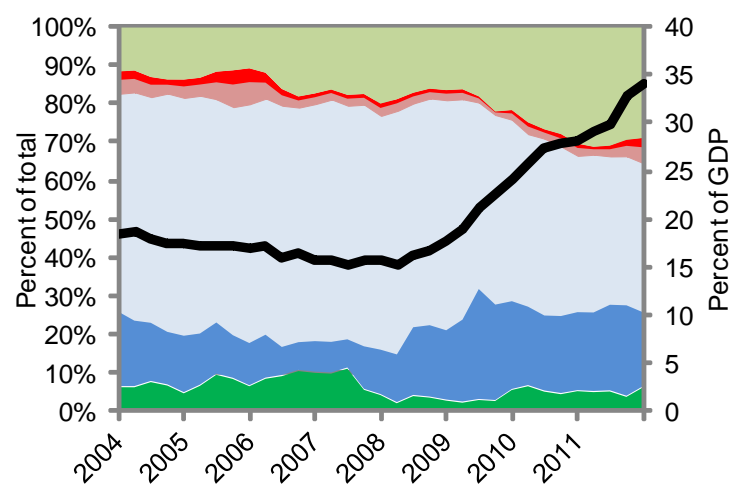

Belgium

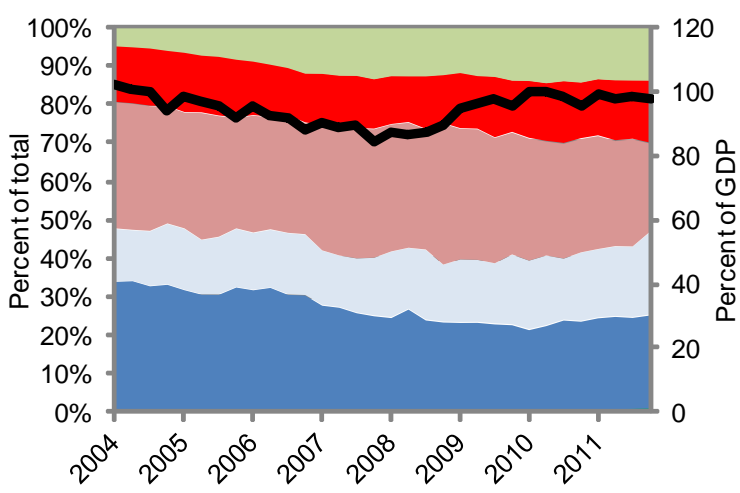

Czech Repulic

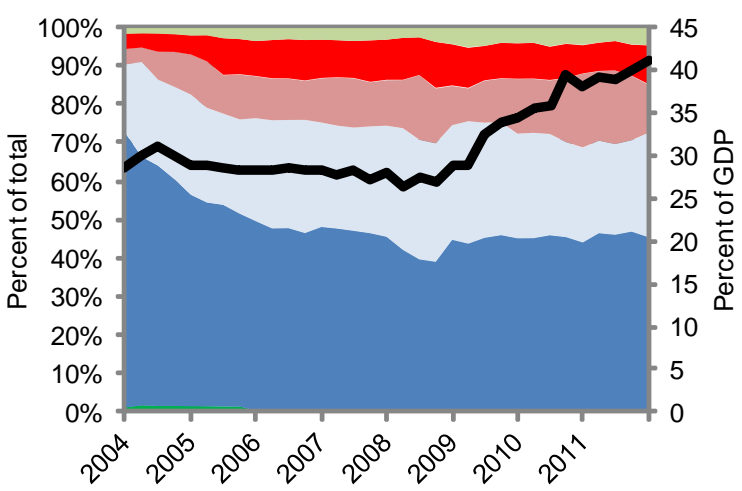

Foreign bank

Total debt (rhs)
Domestic central bank

Austria

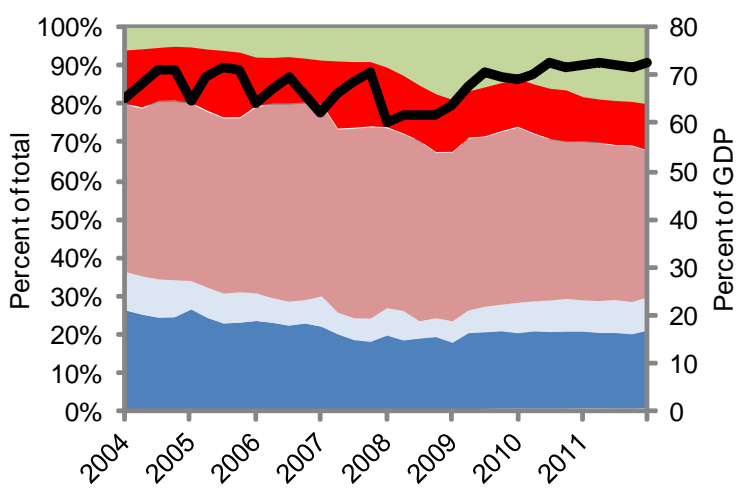

Canada

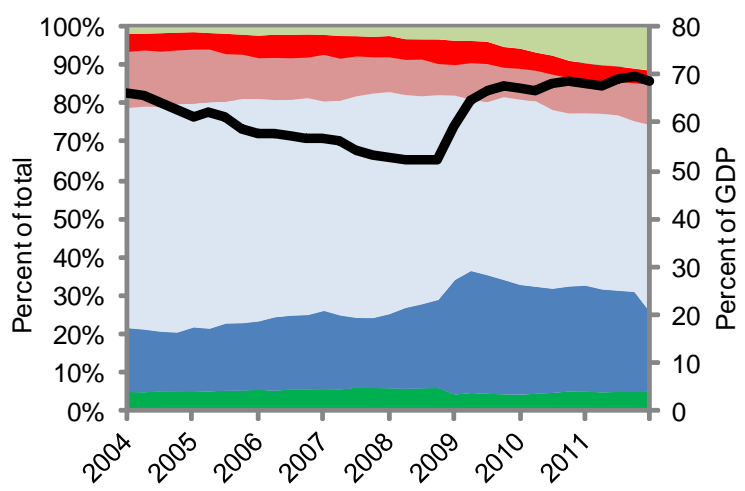

Denmark

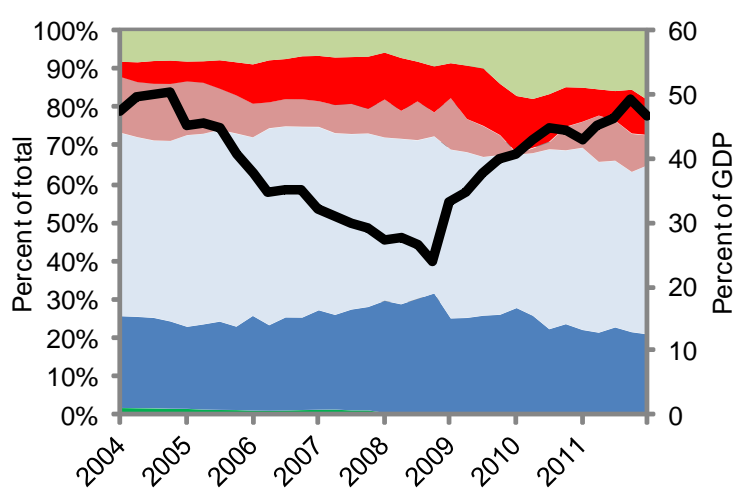

Source: Authors' calculations.

Note: Government debt indicates general government gross debt on a consolidated basis, which excludes intergovernmentalh oldings. Do mestic banks are depository co rporations residing in the country (IFS definition). Foreign banks are BIS reporting banksresiding outside the country. Fo reign official includes foreign central bank holdings as foreign exchange reserves, SMP holdings of foreign central banks, and foreign official loans. Fo reign nonbanks and domestic nonbanks are imputed from external and total debt. 
Annex Figure 1. Advanced Economies: Holders of Government Debt, 2004-11 (continued) (components in percent; total in percent of GDP)

Foreign bank Total debt (rhs)
Domestic central bank Foreign official
Domestic nonbank
Foreign nonbank

Finland

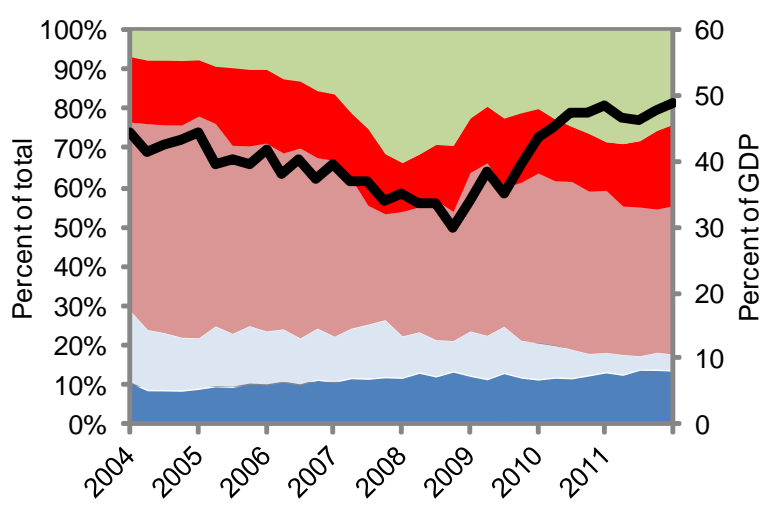

Germany

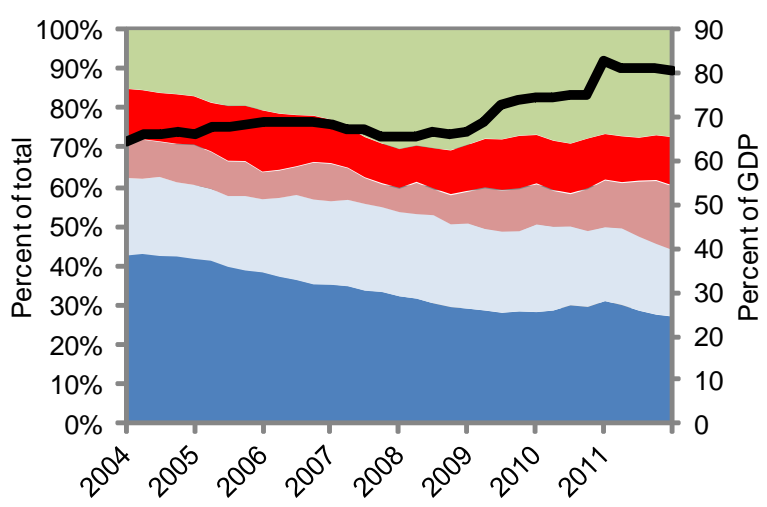

Ireland

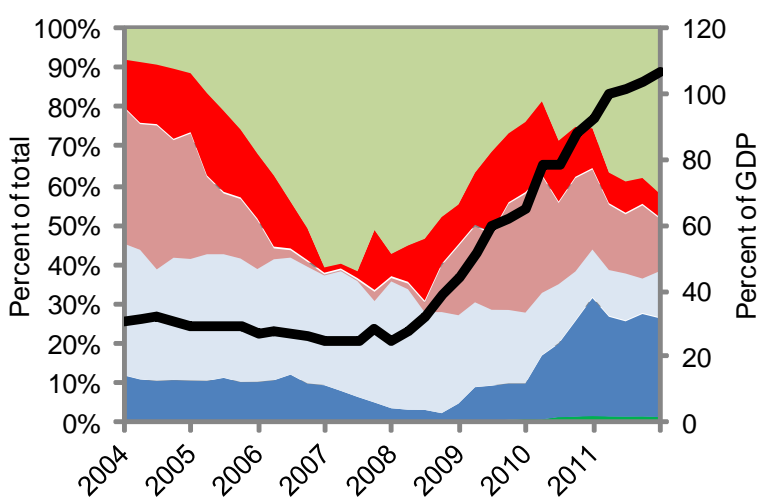

France

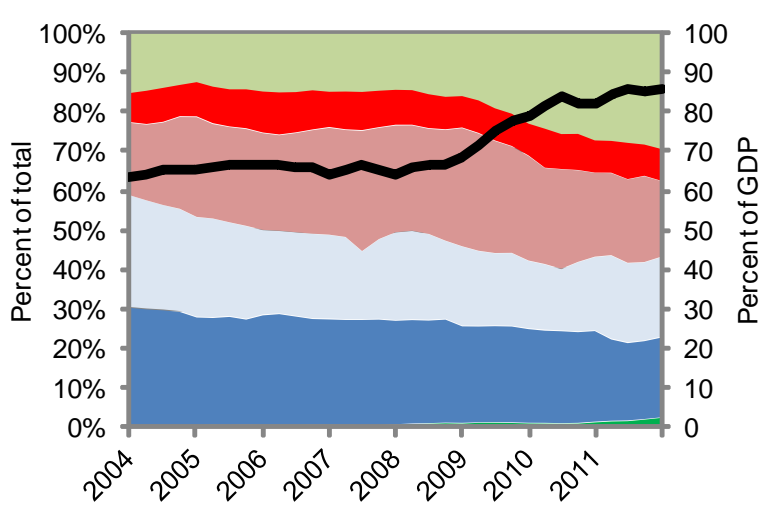

Greece

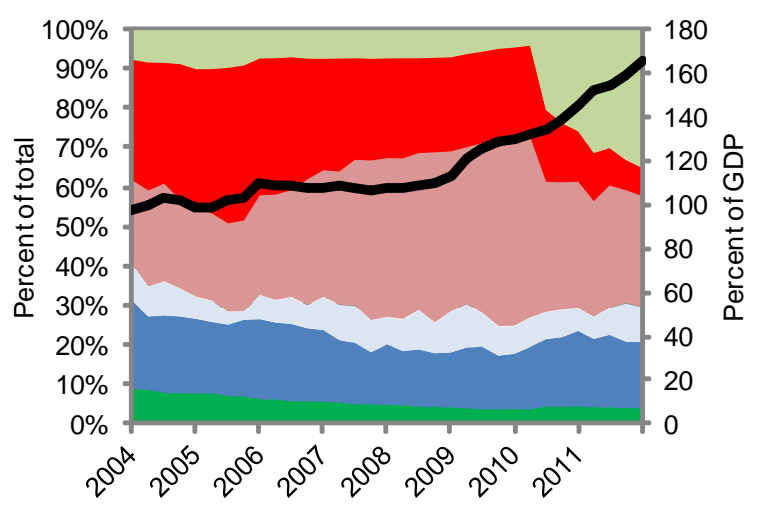

Italy

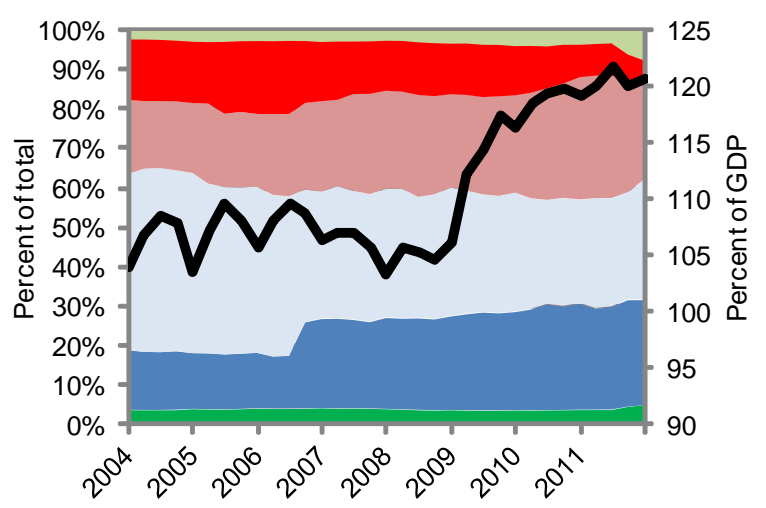

Source: Authors' calculations.

Note: Government debt indicates general government g ross debt on a con solidated basis, which excludes intergovernmentalholdings. Do mestic banks are depository corporations residing in the country (IFS definition). Foreign banks are BIS reporting banksresiding outside the country. Fo reign official includes foreign central bank holdings as foreign exchange reserves, SMP holdings of foreign central banks, and foreign official loans. Fo reign nonbanks and domestic nonbanks are imputed from external and to tal debt. 
Annex Figure 1. Advanced Economies: Holders of Government Debt, 2004-11 (continued) (components in percent; total in percent of GDP)

Foreign official

Domestic nonbank
Foreign bank

Total debt (rhs)
Domestic central bank

\section{Korea}

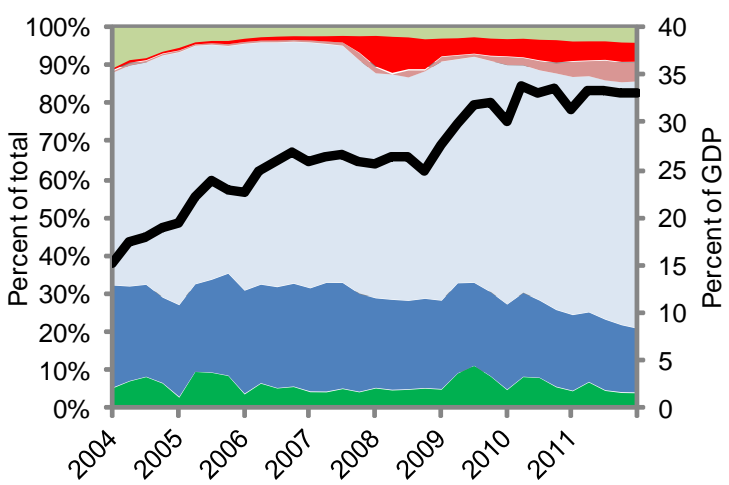

New Zeland

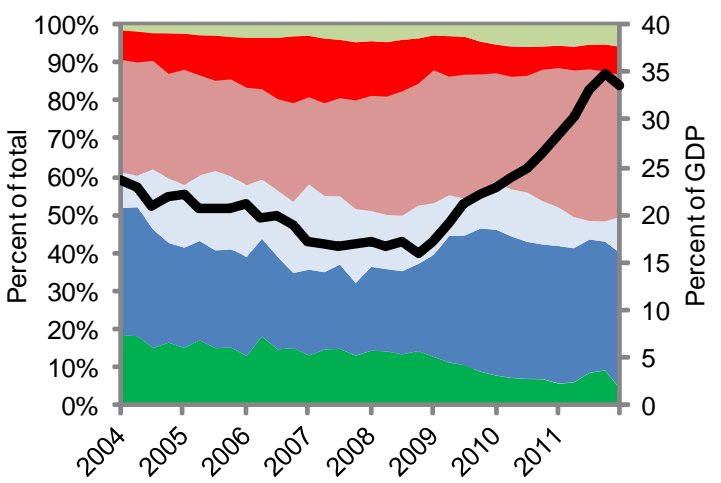

Portugal

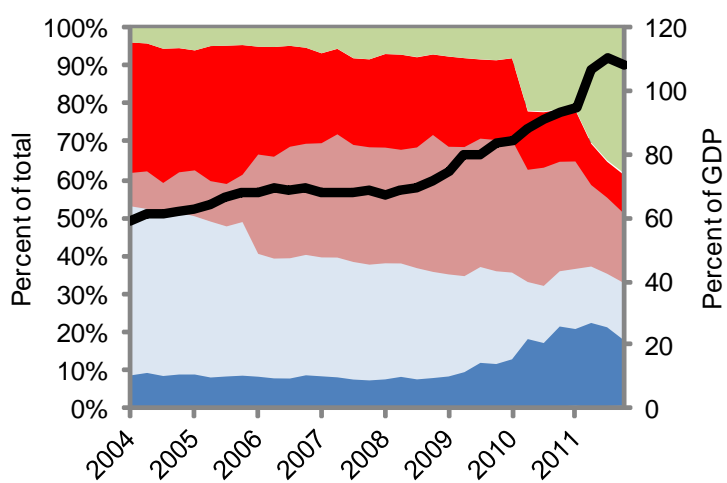

Source: Authors' calculations.

Note: Govemment debt indicates general govemment g ross debt on a con solidated basis, which excludes intergovernmental holdings. Domestic banks are depository co rporations residing in the country (IFS definition). Foreign banks are BIS reporting banks residing outside the country. Fo reign official includes foreign central bank holdings as foreign exchange reserves, SMP holdings of fo reign central banks, and foreign official loans. Foreign nonbanks and domestic nonbanks are imputed from external and to tal debt. 
Annex Figure 1. Advanced Economies: Holders of Government Debt, 2004-11 (continued) (components in percent; total in percent of GDP)

Foreign official

Domesticnonbank
Foreign nonbank

Domestic bank
Foreign bank

Total debt (rhs)
Domestic central bank

Spain

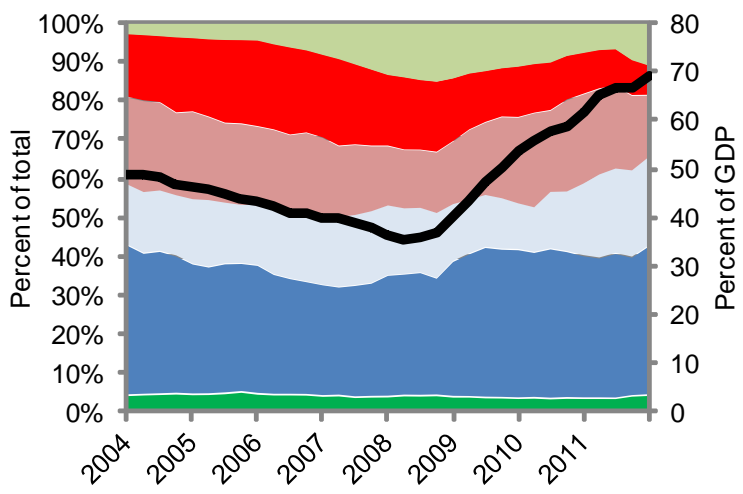

Switzerland

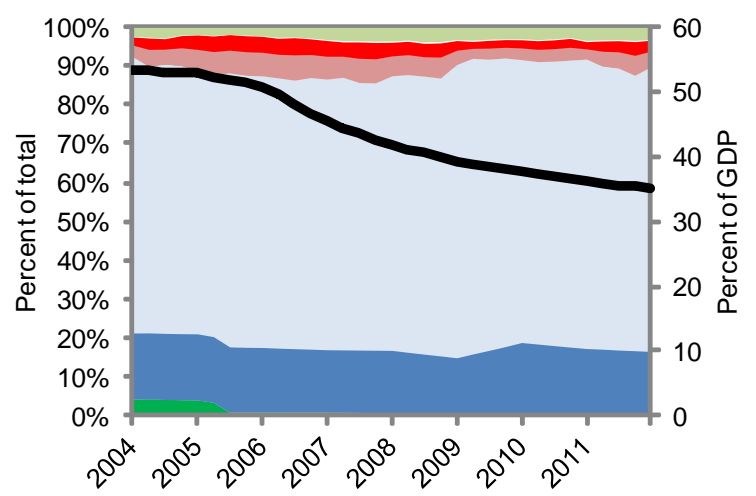

United Kingdom

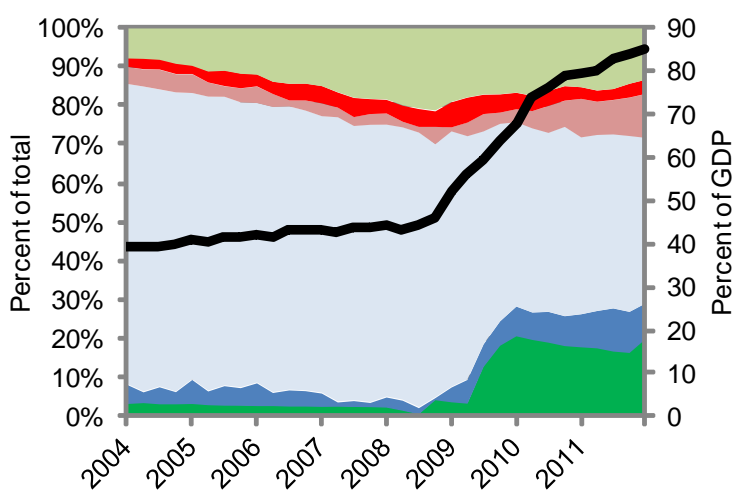

\section{United States}

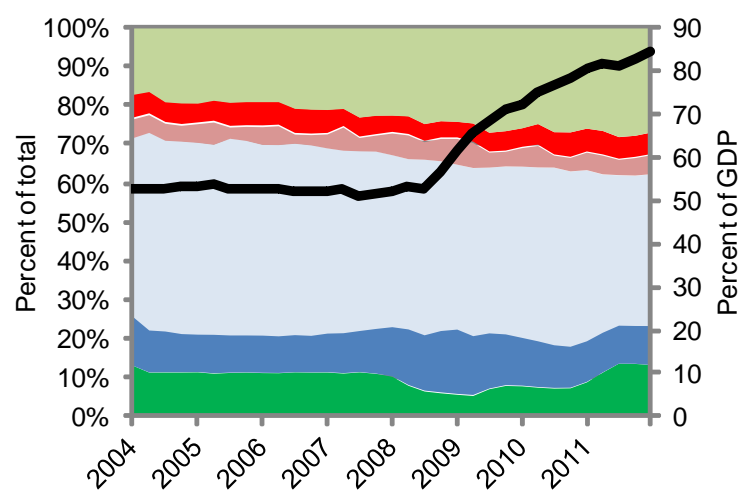

Source: Authors' calculations.

Note: Government debt indicates general government g ross debt on a consolidated basis, which excludes intergovernmental holdings. Domestic banks are depository co rporations residing in the country (IFS definition). Foreign banks are BIS reporting banks residing outside the country. Fo reign official in cludes foreign central bank holdings as fo reign exchange reserves, SMP holdings of fo reign central banks, and foreign official loans. Foreign nonbanks and domestic nonbanks are imputed from external and to tal debt. 
Annex Figure 1. Advanced Economies: Holders of Government Debt, 2004-11 (continued) (components in percent; total in percent of GDP)

Foreign official Domestic nonbank

High-Spread Euro Area

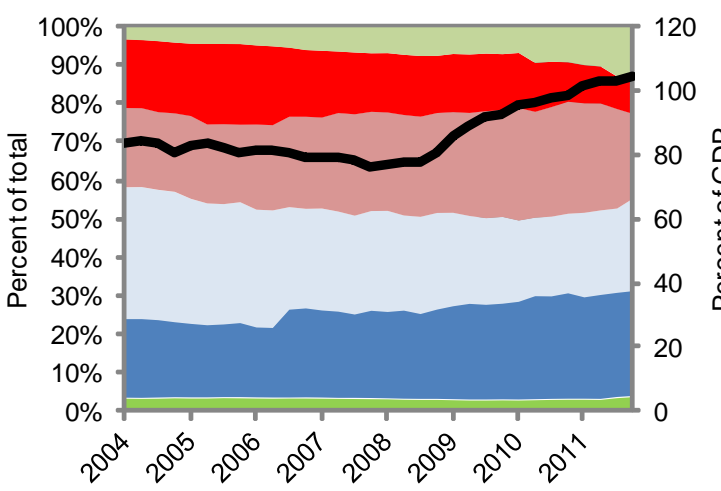

Traditional Reserve Countries

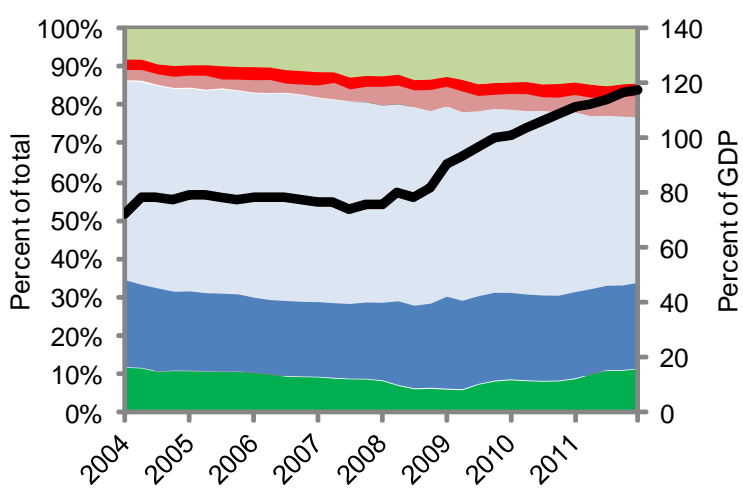

G7

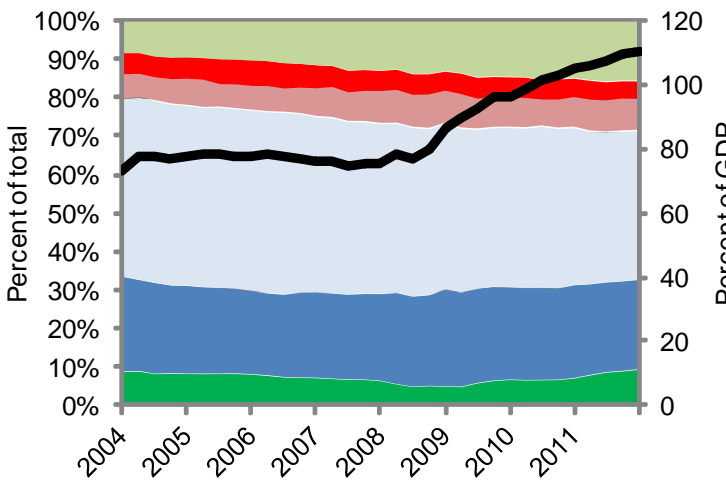

Foreign bank

Total debt (rhs)
Domestic central bank Low-Spread Euro Area

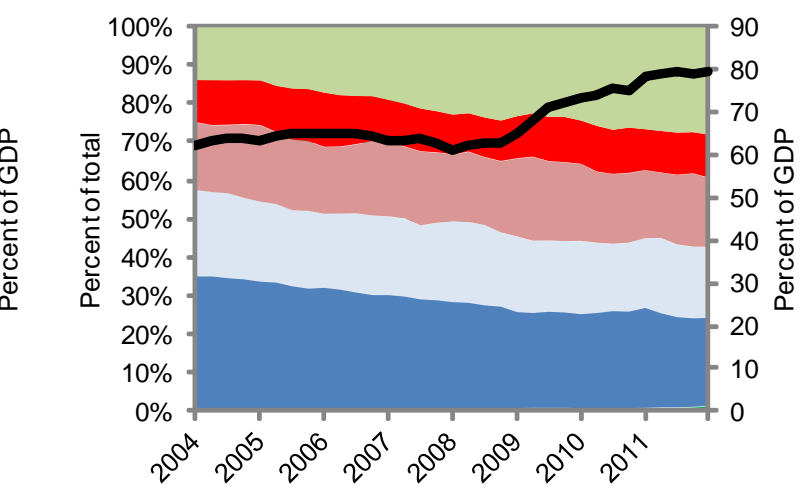

Other Advanced Economies

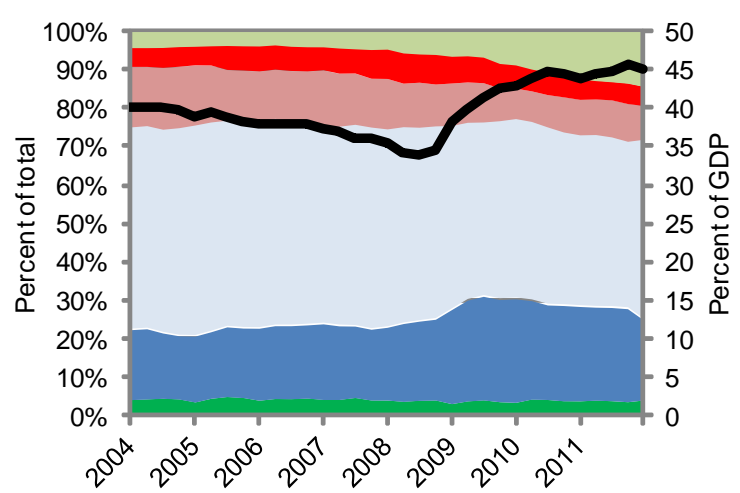

All Countries

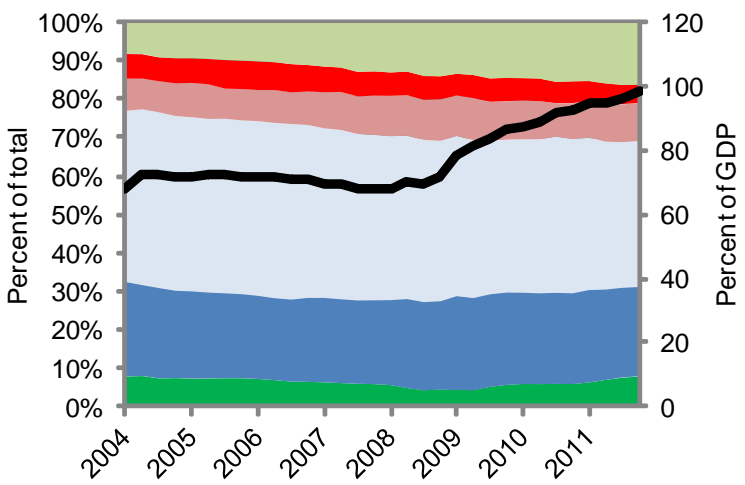

Source: Authors' calculations.

Note: Government debt indicates g eneral government g ross debt on a con solidated basis, which excludes intergovernmentalholdings. Do mestic banks are depository co rporations residing in the country (IFS definition). Foreign banks are BIS reporting banksresiding outside the country. Fo reign official includes foreign central bank holdings as fo reign exchange reserves, SMP holdings of foreign central banks, and foreign official loans. Fo reign nonbanks and domestic nonbanks are imputed from external and total debt. 


\section{Annex Figure 2. Advanced Economies: Cumulative Net Purchases of Government Debt by Investor Type, 2008-11}

\begin{abstract}
Domestic central bank
-Foreign bank
\end{abstract}

Domesticbank

Foreign nonbank

\section{Domestic nonbank}

Foreign officialloans
Foreign centralbank

SMP_external

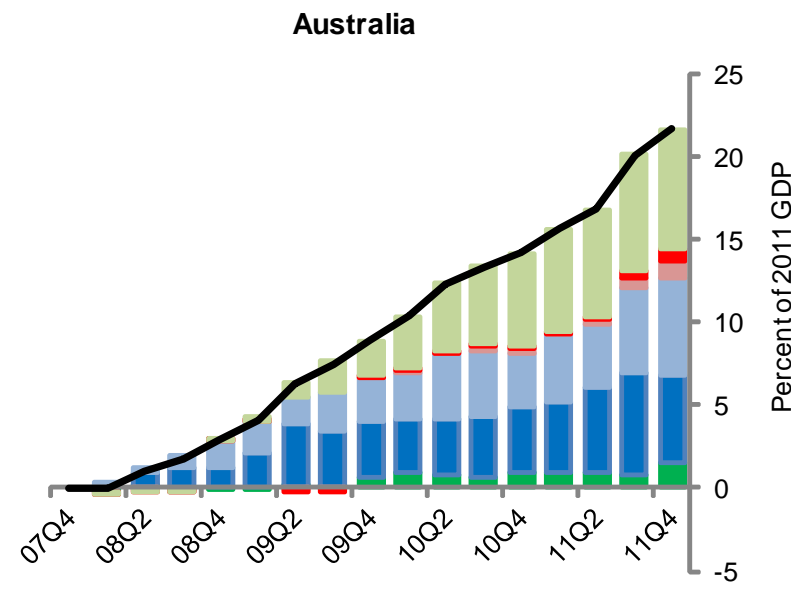

Belgium

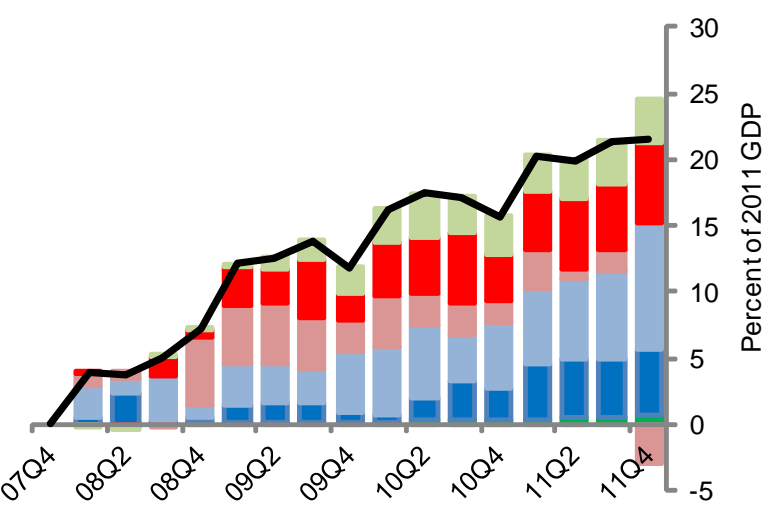

Austria

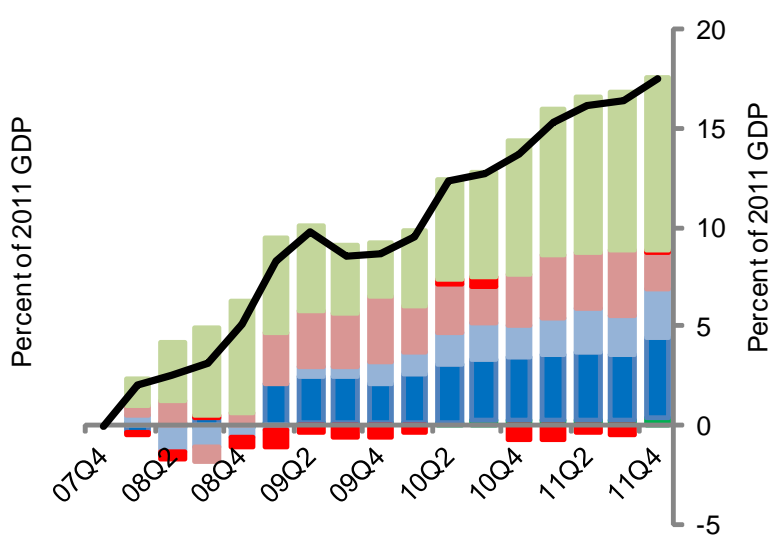

Canada

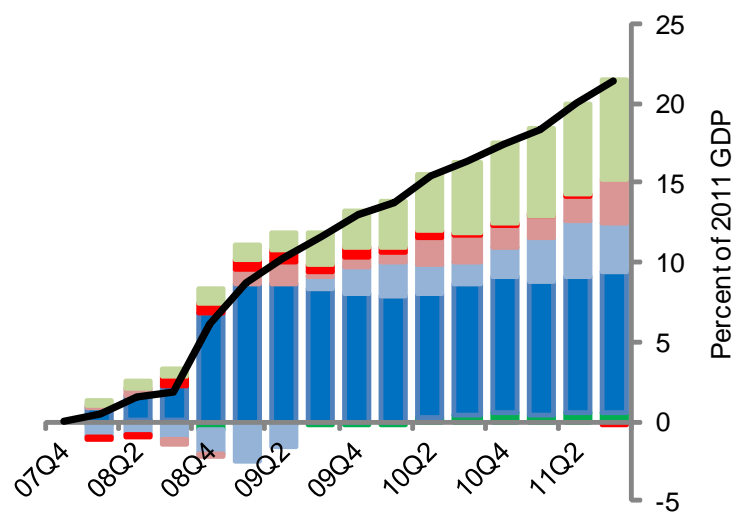

\section{Czech Repulic}

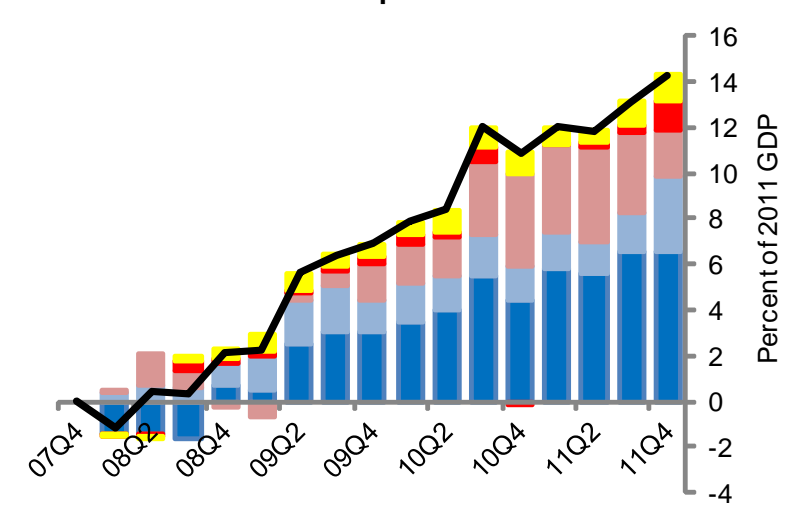

Denmark

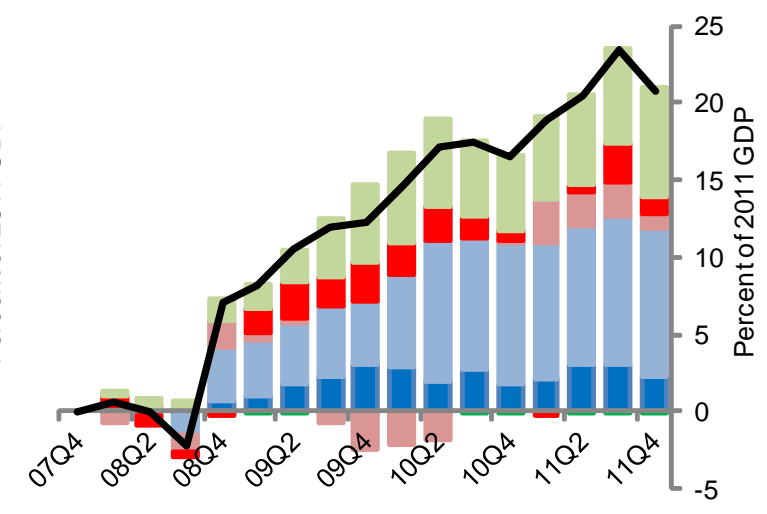

Source: Authors' calculations.

Note: Government debt indicates general government gross debt on a consolidated basis, which excludes intergovernmentalh oldings Domestic banks are depository corporations residing in the country (IFS definition). Foreign banks are BIS reporting banksresiding outside the country. Fo reign central bankindicates government debt holdings as foreign exchange reserves. SMP_external indicates SMP holdings of fo reign central banks. Foreign nonbanks and domestic nonbanks are imputed from external and to tal debt. 
Annex Figure 2. Advanced Economies: Cumulative Net Purchases of Government Debt by Investor Type, 2008-11 (continued)

Domestic central bank

a Foreign bank
Domesticbank

Foreign nonbank
Domestic nonbank

Foreign officialloans
Foreign centralbank

SMP_external
Finland

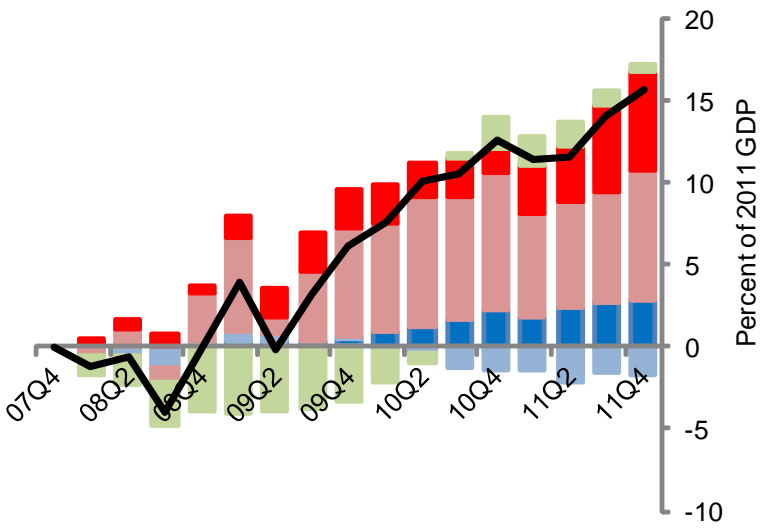

Germany

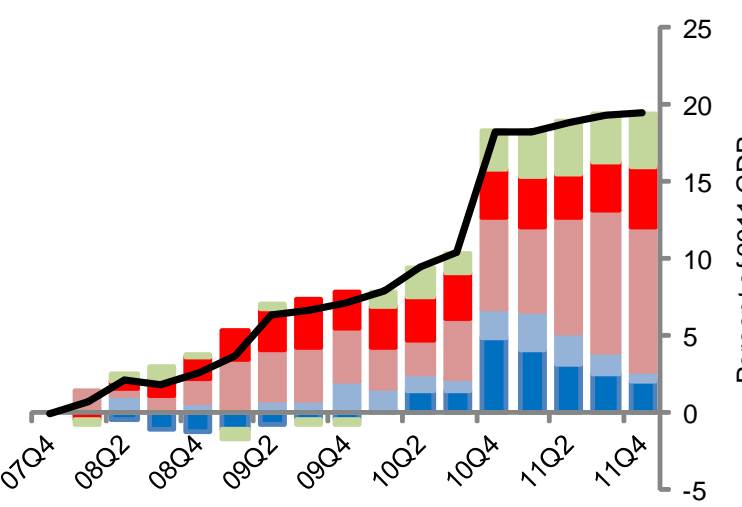

Ireland

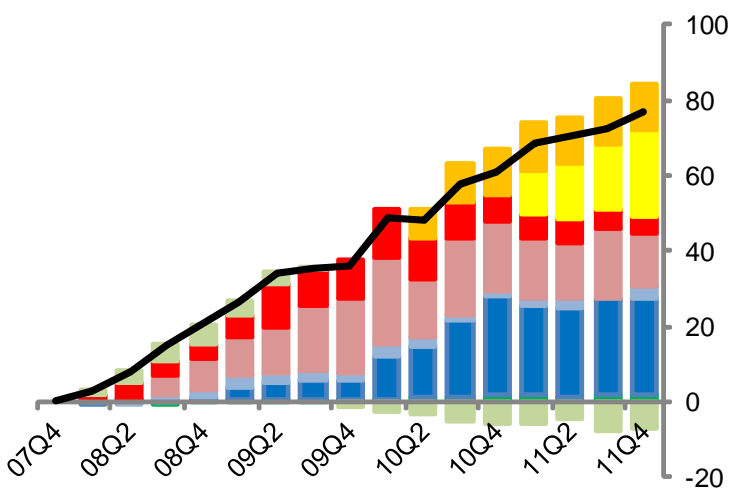

France

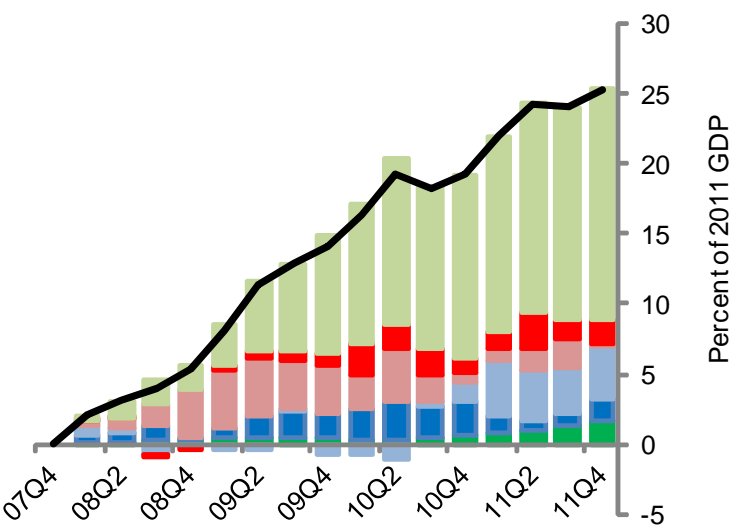

Greece

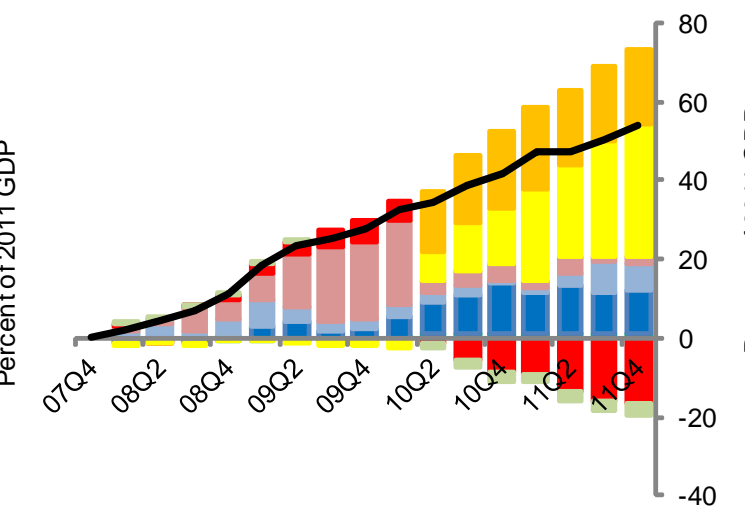

Italy

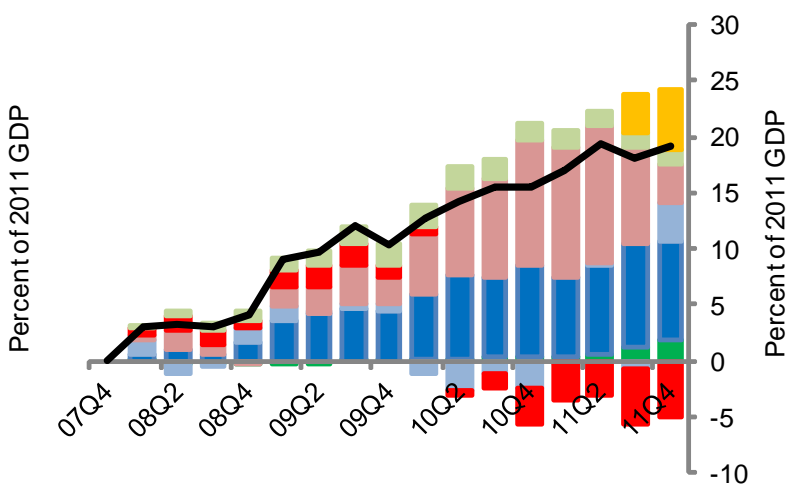

Source: Authors' calculations.

Note: Government debt indicates general government gross debt on a consolidated basis, which excludes intergovernmentalholdings. Domestic banks are depository co rporations residing in the country (IFS definition). Foreign banks are BIS reporting banksresiding outside the country. Fo reign central bank indicates government debt holdings as foreign exchange reserves. SMP_external indicates SMP holdings of foreign central banks. Foreign nonbanks and domestic nonbanks are imputed from external and total debt. 
Annex Figure 2. Advanced Economies: Cumulative Net Purchases of Government Debt by Investor Type, 2008-11 (continued)

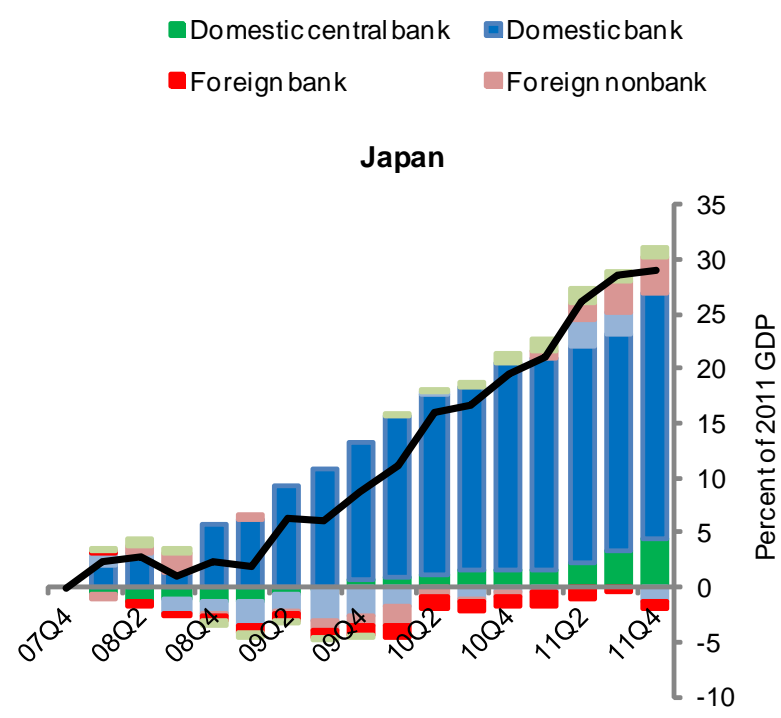

Netherlands

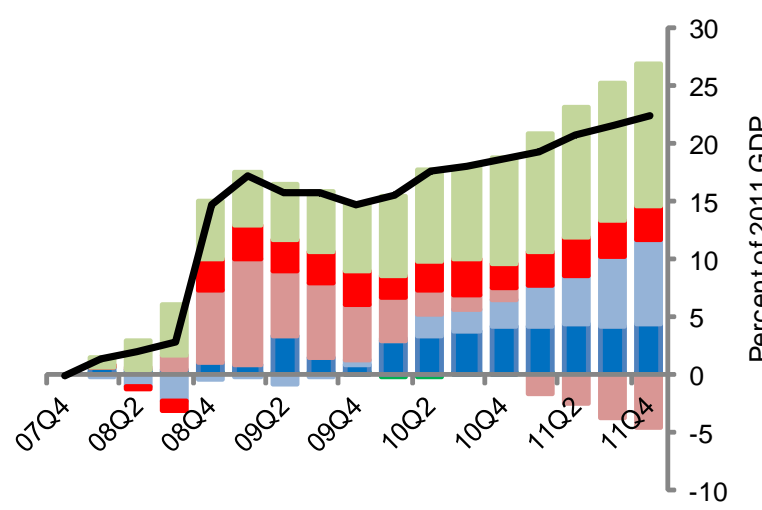

Domesticnonbank Foreign centralbank

Foreign officialloans SMP_external

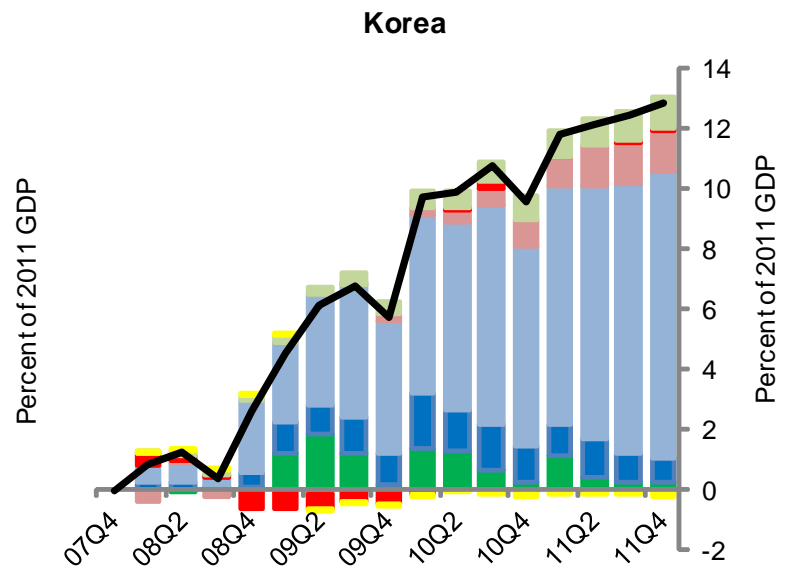

New Zealand

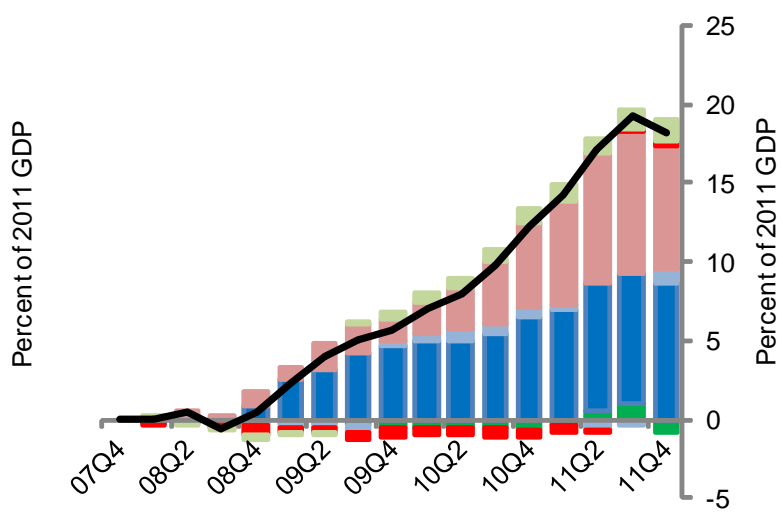

Norway

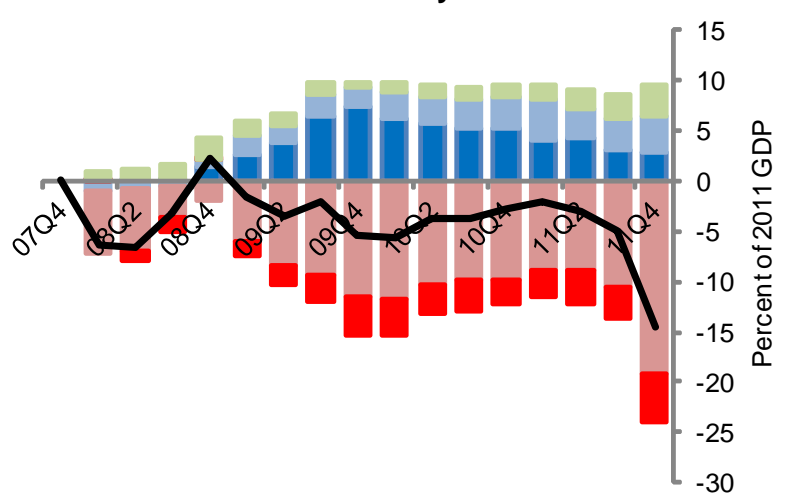

Portugal

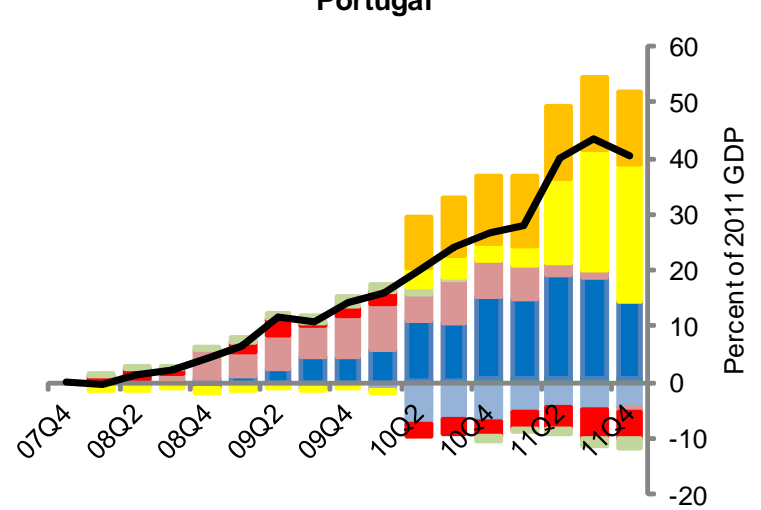

Source: Authors' calculations.

Note: Government debt indicates general government g ross debt on a con solidated basis, which excludes intergovernmentalh oldings. Domestic banks are depository corporations residing in the country (IFS definition). Foreign banks are BIS reporting banksresiding outside the country. Fo reign central bank indicates government debt holdings as foreign exchange reserves. SMP_external indicates SMP holdings of fo reign central banks. Foreign nonbanks and domestic nonbanks are imputed from external and total debt. 
Annex Figure 2. Advanced Economies: Cumulative Net Purchases of Government Debt by Investor Type, 2008-11 (continued)

Domestic central bank
Foreign bank

Slovenia

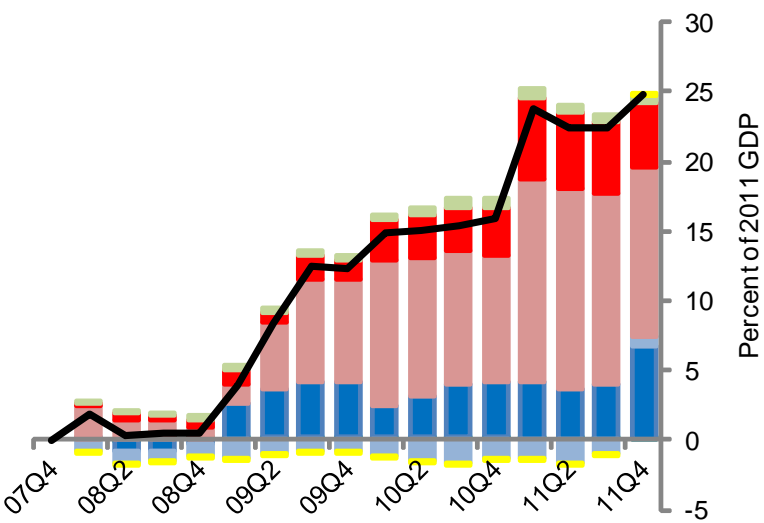

Sweden

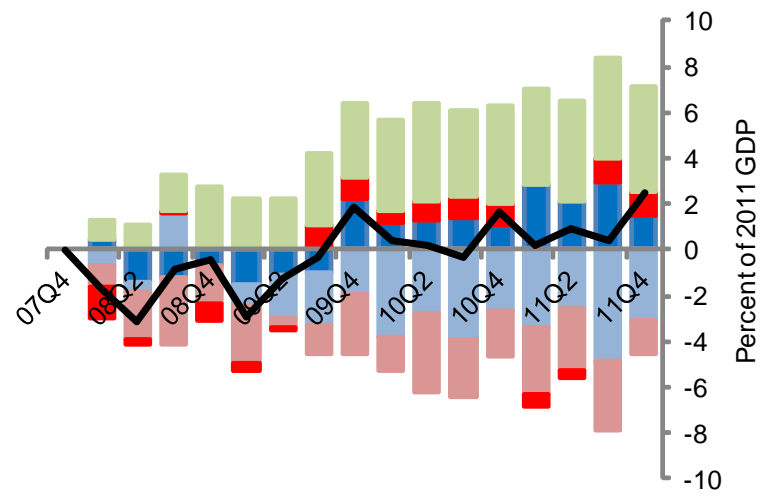

\section{United Kingdom}

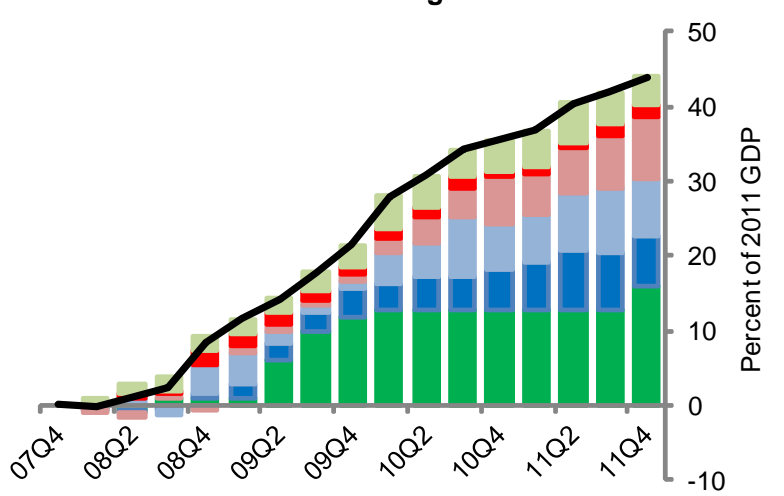

Domesticnonbank Foreign centralbank

Foreign officialloans SMP_external
Spain

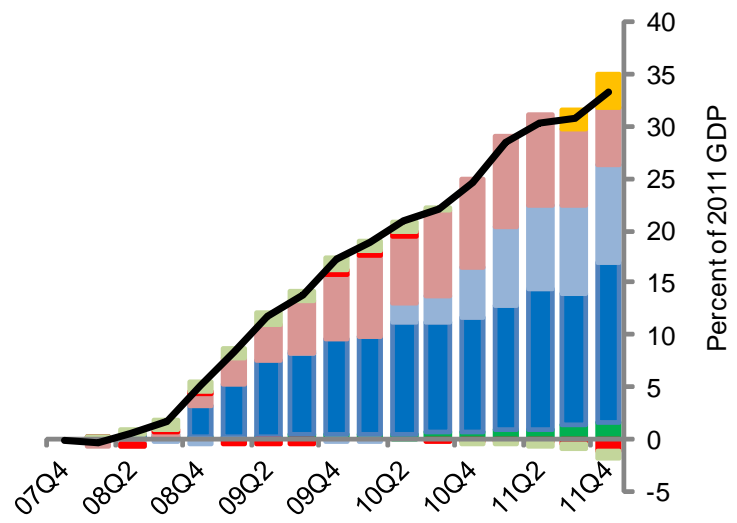

Switzerland

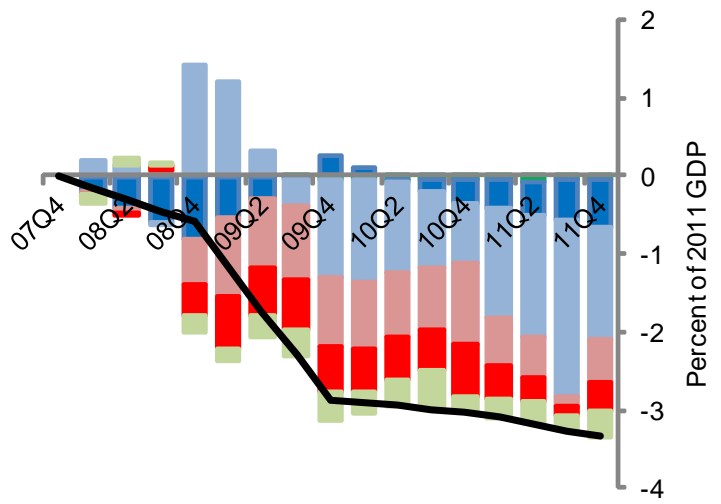

United States

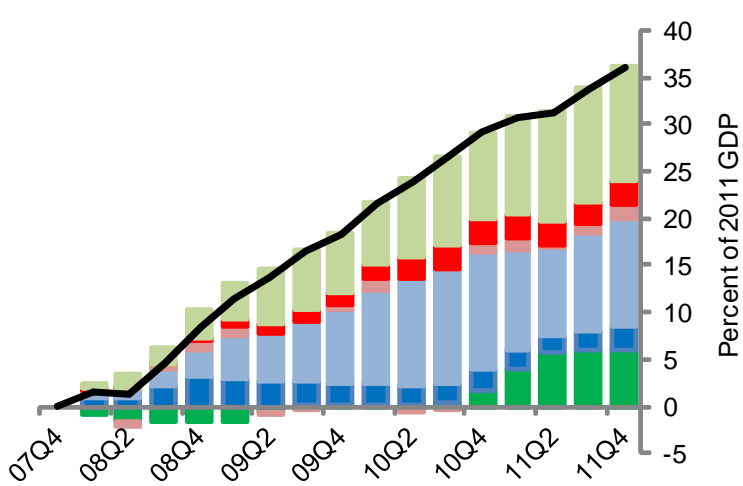

Source: Authors' calculations.

Note: Government debt indicates general government gross debt on a consolidated basis, which excludes intergovernmentalholdings. Domestic banks are depository co rporations residing in the country (IFS definition). Foreign banks are BIS reporting banksresiding outside the country. Foreign central bank indicates government debt holdings as foreign exchange reserves. SMP_external indicates SMP holdings of foreign central banks. Foreign nonbanks and domestic nonbanks are imputed from external and total debt. 
Annex Figure 2. Advanced Economies: Cumulative Net Purchases of Government Debt by Investor Type, 2008-11 (continued)

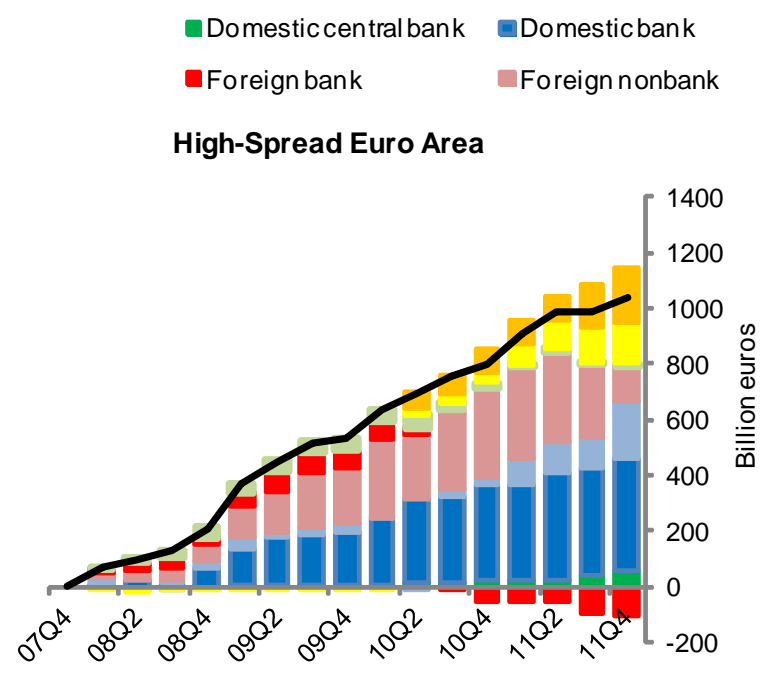
Domesticnonbank Foreign centralbank
Foreign officialloans SMP_external

\section{Low-Spread Euro Area}

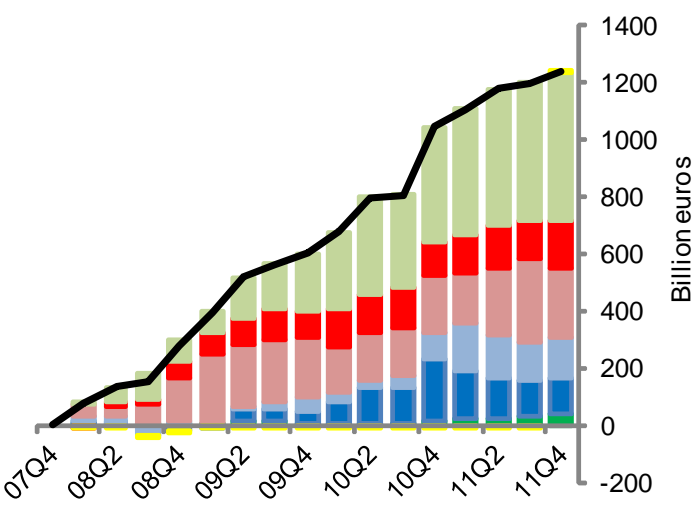

Traditional Reserve Countries

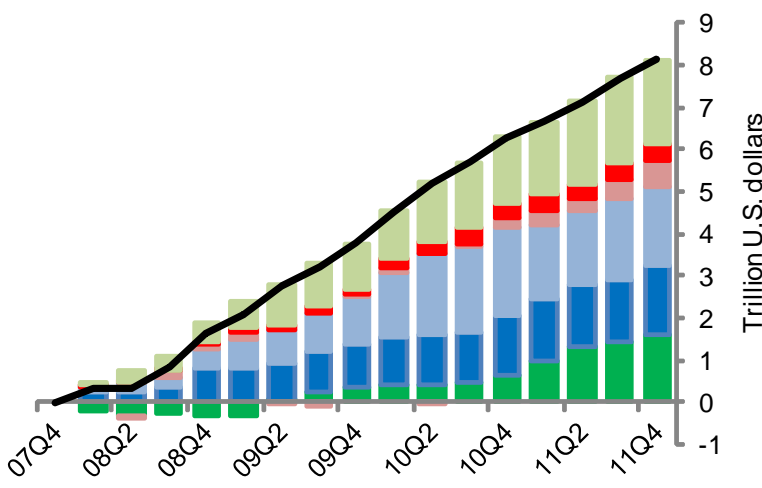

Other Advanced Economies

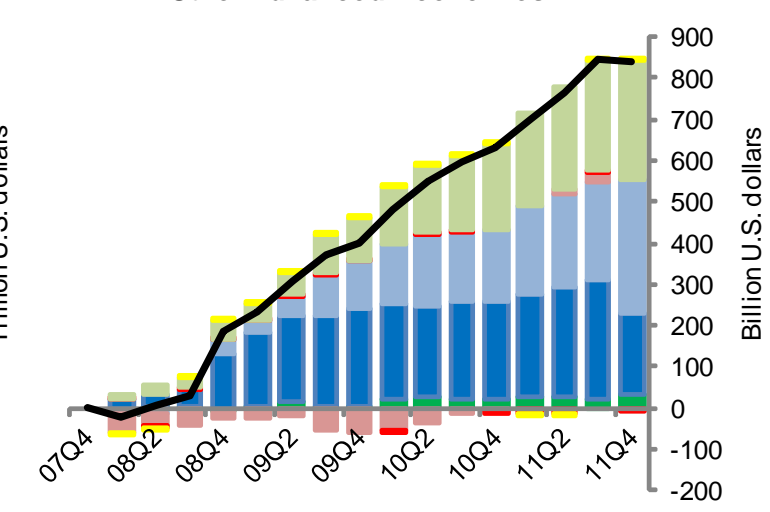

G7

All Countries
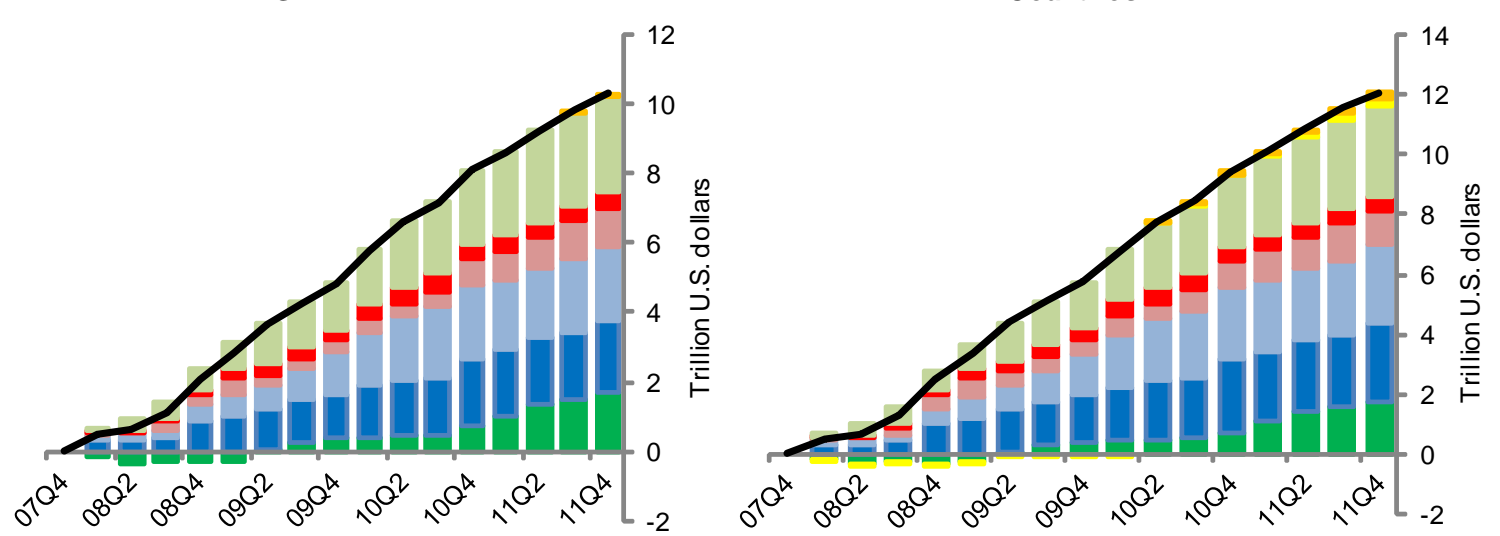

Source: Authors' calculations.

Note: Government debt indicates general government g ross debt on a consolidated basis, which excludes intergovernmentalholdings. Do mestic banks are depository co rporations residing in the country (IFS definition). Foreign banks are BIS reporting banksresiding outside the country. Fo reign central bank indicates government debt holdings as foreign exchange reserves. SMP external indiates SMP holdings of fo reign central banks. Foreign nonbanks and domestic nonbanks are imputed from external and total debt. 


\section{References}

Acharya, V., I. Drechsler, and P. Schnabl, 2012, "A Tale of Two Overhangs: The Nexus of Financial Sector and Credit Risks," Banque de France Financial Stability Report, No16, April 2012.

Adler, G, 2012, "Intertwined Sovereign and Bank Solvencies in a Model of Self-Fulfilling Crisis,” IMF Working Paper No. 12/178 (Washington: International Monetary Fund).

Agell, J., M. Persson, and B. Friedman, 1992, “Does Debt Management Matter?” Oxford Clarendon.

Andritzky, J. R., 2012, "Government Bonds and Their Investors: What Are the Facts and Do They Matter?” IMF Working Paper No. 12/158 (Washington: International Monetary Fund).

Bank for International Settlement, 2002, “The Development of Bond Markets in Emerging Economies,” BIS Papers No 11.

Bank for International Settlement, 2011, “The Impact of Sovereign Credit Risk on Bank Funding Conditions," CGFS Paper No 43.

Bernanke, B. S., V. R. Reinhart, and B. P. Sack, 2004, "Monetary Policy Alternatives at the Zero Bound: An Empirical Assessment" Brookings Papers on Economic Activity, 35(2004-2), 1-100

Blommestein, H., A. Harwood, and A. Holland, 2011, "The Future of Debt Markets," OECD Journal: Financial Market Trends, Volume 2011, Issue 2.

Calvo, G., and E. Talvi, 2005, "Sudden stops, financial factors and economic collapses in Latin America: lessons from Argentina and Chile," NBER Working Paper Series, No. 11153.

Calvo, G., A. Izquierdo, A, and L. Mejía, 2004, "On the Empirics of Sudden Stops: the Relevance of Balance-Sheet Effects," NBER Working Paper Series, No. 10520.

Daniel, L., 2008, 'Foreign Investors' Participation in Emerging Market Economies' Domestic Bond Markets," Banque de France Bulletin Digest, No. 173, May-June 2008.

Das, U.S., M. Papaioannou, and C. Trebesch, 2012, "Sovereign Debt Restructurings 19502010: Literature Survey, Data, and Stylized Facts," IMF Working Paper No. 12/203 (Washington: International Monetary Fund).

Das, U.S., M. A. Oliva, and T. Tsuda, 2012, "Sovereign Risk: A Macro-Financial Perspective," Asian Development Bank Institute Working Paper No. 383. 
De Santis, R. A., 2012, “The Euro Area Sovereign Debt Crisis: Safe Haven, Credit Rating Agencies and the Spread of the Fever from Greece, Ireland, and Portugal, ECB Working Paper Series No 1419, February 2012.

Ejsing, J., M. Grothe, and O. Grothe, 2012, "Liquidity and Credit Risk Premia in Government Bond Yields,” ECB Working Paper Series No 1440, June 2012.

Frankel, J., 1985, "Portfolio Crowding-Out, Empirically Estimated," Quarterly Journal of Economics, Vol. 100, Supplement (1985), pp. 1041-1065

Friedman, B., and V. Roley, 1980, "Models of Long-Term Interest Rate Determination." The Journal of Portfolio Management, Vol. 6, No. 3, pp. 35-45.

Hyde, N., 2012, “How Safe Are The New Safe Havens?” Standish Mellon Asset Management Company.

International Monetary Fund, 2010, "The Uses and Abuses of Sovereign Credit Ratings" in Global Financial Stability Report (October 2010).

International Monetary Fund, 2011a, "Managing Sovereign Debt and Debt Markets Through a Crisis: Practical Insights and Policy Lessons," IMF Board Paper (Washington: International Monetary Fund).

International Monetary Fund, 2011b, “Overcoming Political Risks and Crisis Legacies" in Global Financial Stability Report (September 2011).

International Monetary Fund, 2012, “Sovereigns, Banks, Emerging Markets: Detailed Analysis \& Policies” in Global Financial Stability Report (April 2012).

Lojsch, D. H., M. Rodríguez-Vives, and M. Slaví. 2011, "The Size and Composition of Government Debt in the Euro Area," ECB Occasional Paper Series No 132, October 2011.

McGuire, P., and P. Wooldridge. 2005, "The BIS Consolidated Banking Statistics: Structure, Uses, and Recent Enhancements.” BIS Quarterly Review, pp. 73-86, September 2005.

Merler S. and J. Pisani-Ferry, 2012a, "Who is Afraid of Sovereign Bonds?" Bruegel Policy Contribution, No. 2012/02.

Merler, S. and J. Pisani-Ferry, 2012b, "Hazardous Tango: Sovereign-Bank Interdependence and Financial Stability in the Euro Area," Banque de France, Financial Stability Review, No. 16, April 2012.

Merler S. and J. Pisani-Ferry, 2012c, "Sudden Stops in the Euro Area," Bruegel Policy Contribution, No. 2012/06. 
OECD, Annual Statistics on Institutional Investors' Assets, Available at: http://www.oecd.org/LongAbstract/0,3425,en_2649_34247_38041646_1_1_1_1,00.h $\underline{\mathrm{tml}}$

Santos, A. and D. Elliott, 2012, "Estimating the Costs of Financial Regulation" IMF Staff Discussion Note, SDN/12/11 (Washington: International Monetary Fund).

Turner, P., 2012, "Weathering Financial Crises: Domestic Bond Markets in EMEs", BIS Papers No 63.

Vause, N. and G. von Peter, 2011, "Euro Area Sovereign Crisis Drives Global Financial Markets,” BIS, Quarterly Review (December 2011).

Warnock, F.E., and V. Warnock, 2009, International Capital Flows and U.S. Interest Rates, Journal of International Money and Finance 28: 903-919.

World Bank and International Monetary Fund, 2001, "Developing Government Bond Markets: A Handbook," World Bank Publications (Washington: International Monetary Fund). 